
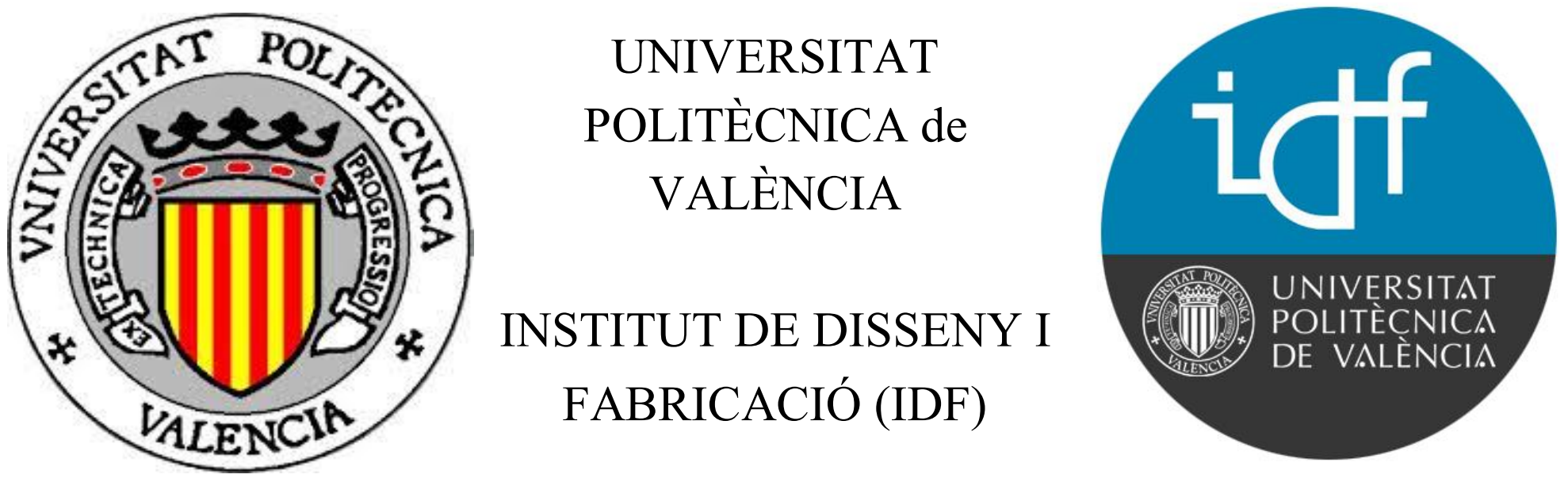

\title{
THIN FILM SOLAR CELLS BASED ON COPPER-INDIUM- GALIUM SELENIDE (CIGS) MATERIALS DEPOSITED BY ELECTROCHEMICAL TECHNIQUES
}

BY

\begin{abstract}
SHAFI ULLAH
A dissertation Submitted in partial fulfillment of the requirements for the degree of Doctor of Philosophy.
\end{abstract}

Supervised by: Prof Dr. Bernabé Marí Soucase

Departamento de Física Aplicada-IDF

Universitat Politécnica de Valencia (Spain)

JUNE 2017 
This page intentionally left blank 


\section{Table of Contents}

List of abbreviations and symbols ....................................................... 5

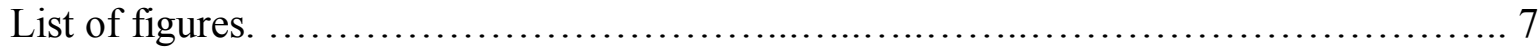

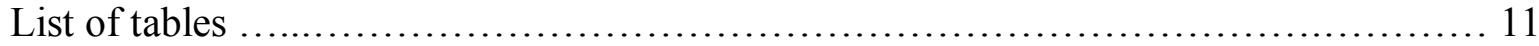

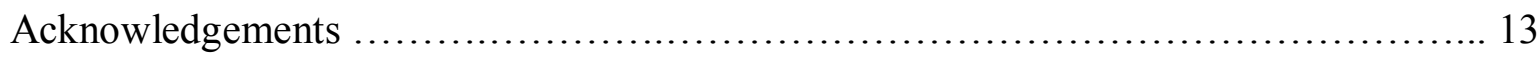

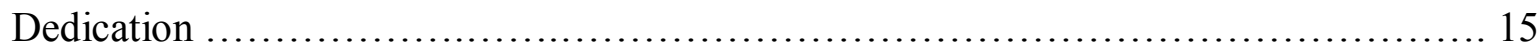

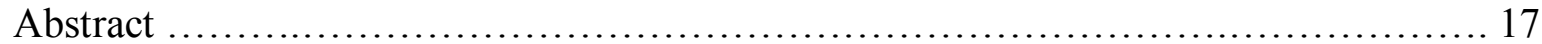

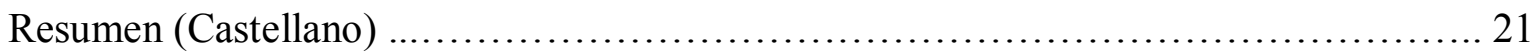

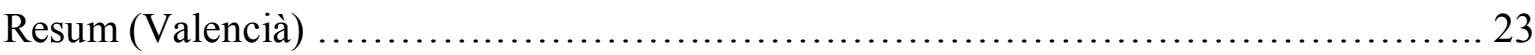

\section{Chapter 1 Introduction}

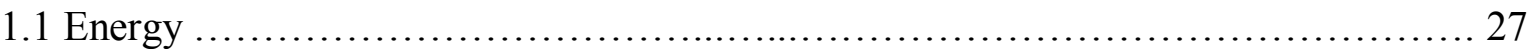

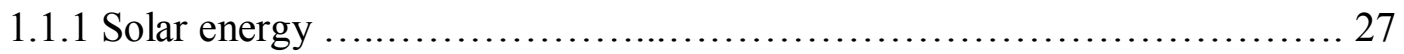

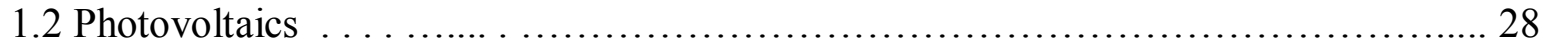

1.2.1 Different Generations of (Photovoltaic) Solar Cell Technology...............29

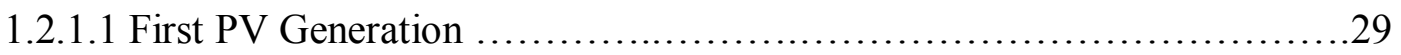

1.2.1.2 Second PV Generation ................................................ 30

1.2.1.3 Third Generation PV Full Spectrum Utilization ........................... 31

1.3 Advantages of Photovoltaic thin films Technology ................................... 31

1.4 Thin-film Solar Cells technology . . . . . ...................................... 32

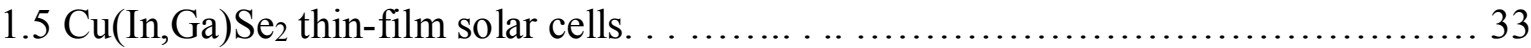

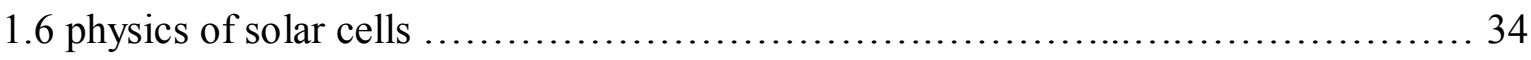

1.6.1 Fabrication of $\mathrm{Cu}(\mathrm{In}, \mathrm{Ga}) \mathrm{Se}_{2}$ thin-film solar cells....................... 35

1.6.2 Energy band diagram of $\mathrm{Cu}(\mathrm{In}, \mathrm{Ga}) \mathrm{Se}_{2}$ thin-film solar cells............... 36

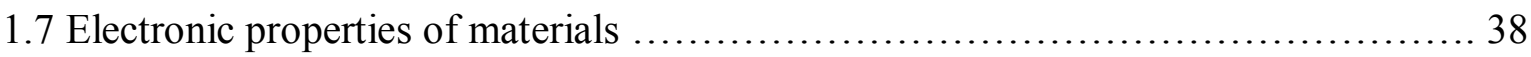

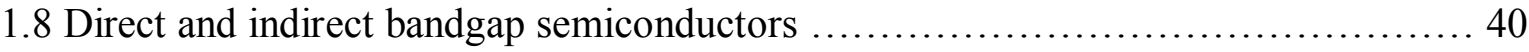

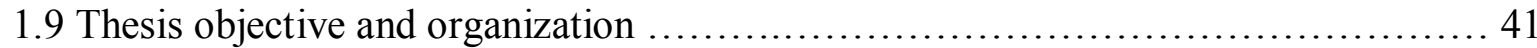

\section{Chapter 2 Experimental, Techniques and Characterization}

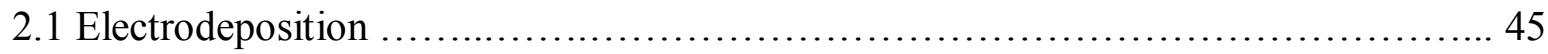

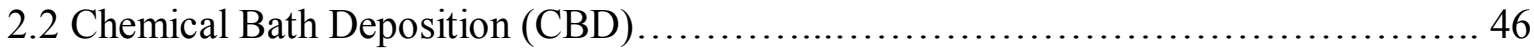

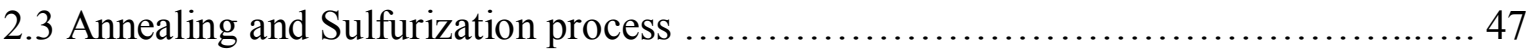

2.4 UV- Visible Spectroscopy ..................................................... 48 


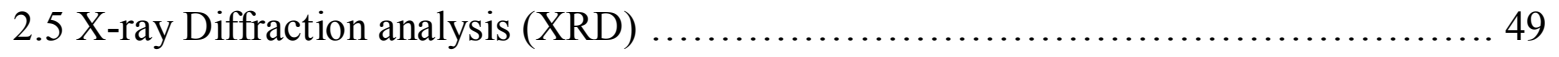

2.6 Field -emission Scanning Electron Microscopy analysis (FESEM) ................... 50

2.7 Energy-dispersive Spectroscopy analysis (EDS) ................................... 51

2.8 Atomic Force Microscopy (AFM) ............................................ 52

2.9 Transmission electron microscopy (TEM) analysis................................ 53

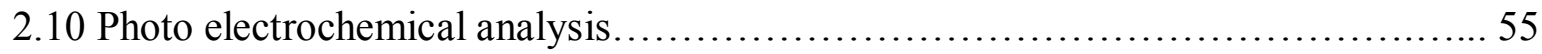

2.11 Current-Voltage (JV) Measurements.......................................... 56

2.12 External quantum efficiency measurement...................................... 58

Chapter 3 Synthesis and characterization of $\mathrm{Cu}(\mathrm{In}, \mathrm{Ga})(\mathrm{Se}, \mathrm{S})_{2}$ thin films

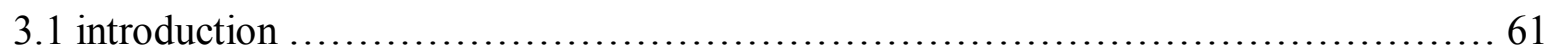

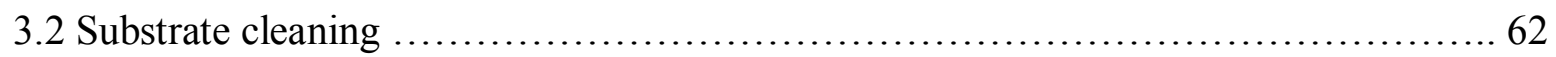

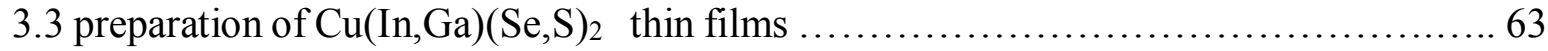

3.3.1 Cyclic voltammetry of the $\mathrm{Cu}(\mathrm{In}, \mathrm{Ga})(\mathrm{Se}, \mathrm{S})_{2}$ thin films ........................ 64

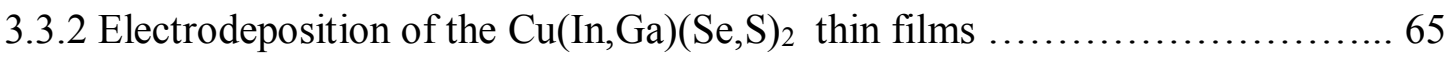

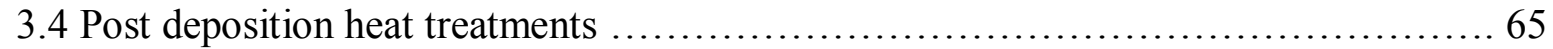

3.5 Engineering of Bandgap by Ga addition and sulfurization.......................... 66

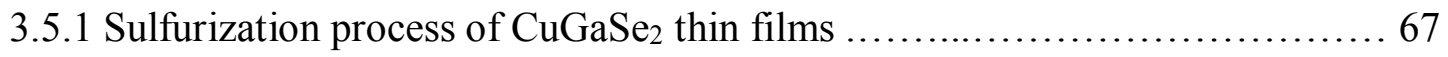

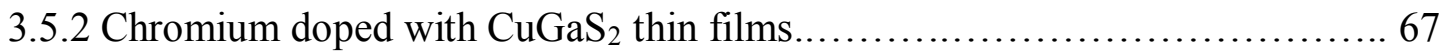

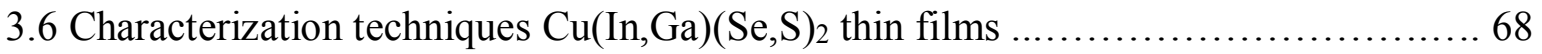

3.6.1 X-Ray diffraction (XRD) analysis ....................................... 68

3.6.2 Scanning Electron Microscopy (SEM) analysis ............................ 70

3.6.3 Energy Dispersive Microscopy (EDS) analysis ............................. 71

3.6.4 Atomic Force Microscopy (AFM) analysis ................................. 74

3.7 Optical analysis of $\mathrm{Cu}(\mathrm{In}, \mathrm{Ga})(\mathrm{Se}, \mathrm{S})_{2}$ thin films ................................... 75

3.7.1 Absorption.............................................................. 75

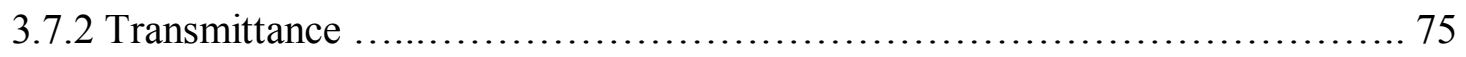

3.7.3 Energy bandgap of $\mathrm{CuGaSe}_{2}, \mathrm{CuGaS}_{2}$ thin films ......................... 76

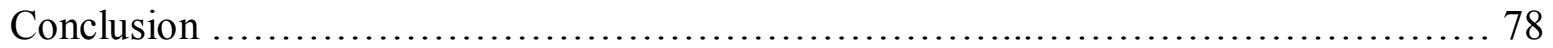

Chapter 4 Buffer layer Synthesis and characterization of CdS and CdZnS thin films

4.1 Introduction of Cadmium sulfide (CdS) and Cadmium zinc sulfide (CdZnS) thin films 


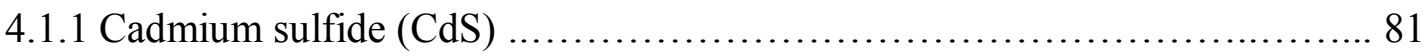

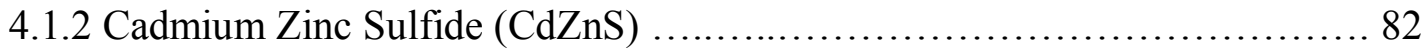

4.1.3 Mechanism of $\mathrm{Cd}_{1-\mathrm{x}} \mathrm{Zn}_{\mathrm{x}} \mathrm{S}$ thin films formation......................... 83

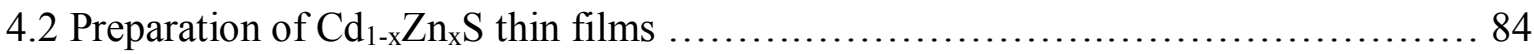

4.2.1 Chemical bath deposition (CBD) process ............................. 86

4.2.2 X-ray difractograms characterization .................................... 86

4.2.3 Scanning electron microscopy characterization........................... 87

4.2.4 Atomic Force Microscopy characterization ….......................... 88

4.2.5 Transmission Electron Microscopy (TEM) Analysis .......................... 90

4.2.6 Optical characterization ................................................ 92

4.2.7 Photo electrochemical analysis (PEC) ....................................... 94

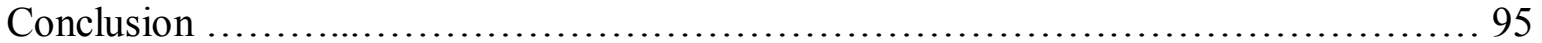

\section{Chapter 5 Simulation studies of $\mathrm{CuGaSe}_{2}, \mathrm{CuGaS}_{2}$ doped by different $\mathrm{Cr}$ at\%}

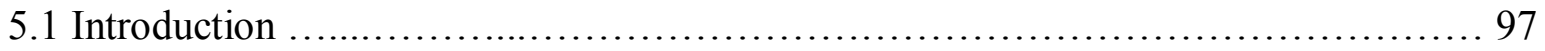

5.2 Preparation of $\mathrm{CuGaSe}_{2}, \mathrm{CuGaS}_{2}$ thin films …................................. 98

5.2.1 X-ray difractograms characterization …............................... 99

5.2.2 Energy dispersive spectroscopy characterization ............................. 101

5.2.3 Optical analysis of the $\mathrm{CuGaSe}_{2}, \mathrm{CuGaS}_{2}$ and $\mathrm{CuGaS}_{2}: \mathrm{Cr}$ thin films ......... 102

5.3 Intermediate band concept and model........................................... 103

5.4 Numerical simulation of solar cells based on $\mathrm{CuGaS}_{2}: \mathrm{Cr}$ absorbers ................ 105

5.4.1 Energy band diagram of $\mathrm{Mo} / \mathrm{CuGaS}_{2} / \mathrm{CdS} / \mathrm{ZnO}$ thin films solar cell ....... 106

5.4.2 External Quantum Efficiency (EQE) of $\mathrm{CuGaS}_{2}: \mathrm{Cr}$ solar cell .............. 107

5.4.3 Current and Voltage characteristics of $\mathrm{CuGaS}_{2}: \mathrm{Cr}$ thin film solar cells...... 108

5.4.4 Current and Voltage characteristics of $\mathrm{CuGaS}_{2}: \mathrm{Cr}$ thin film solar cell with

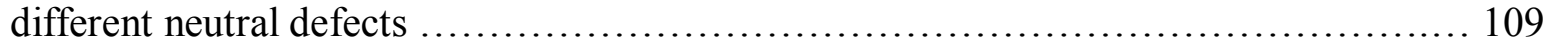

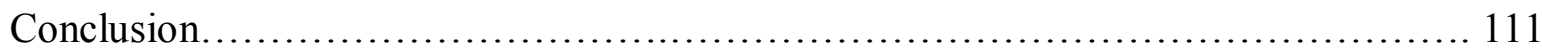

Chapter 6 Conclusions and future work outlook .................................... 113

Summarizes the work presented here and the overall, additionally possible future guidelines in applying the research capabilities and building from the significant results described in this dissertation.

References ................................................................................. 117 
This page intentionally left blank 


\section{List of abbreviations and symbols}

\section{Symbols}

A

AES

AFM

AM 1.5

$\mathrm{BB}$

${ }^{\mathrm{o}} \mathrm{C}$

CB

$\mathrm{CdS}$

CIS

CIGS

$\mathrm{CIGS}_{2}$

CIGSS

$\mathrm{Cu}$

d

EDS

$\mathrm{Eg} / \mathrm{EG}$

EQE

$\mathrm{eV}$

FCC

FF

$\mathrm{Ga}$

$\mathrm{h}$

hkl

IB

IBSC

IGB

$\mathrm{Im}_{\mathrm{m}}$

In abbreviations

Absorbance

Auger Electron Spectroscopy

Atomic Force Microscopy

Air Mass 1.5 Irradiation Spectrum

Black Body

Degree Celsius

Conduction band

Cadmium sulfide

Copper indium diselenide

Copper indium gallium diselenide

Copper indium gallium disulfide

Copper indium gallium selenide sulfide

Copper

lattice spacing in crystal

Energy Dispersive Spectroscopy

Energy band gap

External Quantum efficiency

electron volt

Face centered cubic

Fill Factor in efficiency calculations

Gallium

hour

Miller indices in lattice

intermediate band

Intermediate band solar cell

In gap band

Maximum current of a cell

indium 


\begin{tabular}{|c|c|}
\hline i: $\mathrm{ZnO}$ & intrinsic zinc oxide \\
\hline $\mathrm{J}_{\mathrm{sc}}$ & Short circuit current \\
\hline $\mathrm{KeV}$ & Kilo electron Volt \\
\hline $\mathrm{ml}$ & Milliliter \\
\hline Mo & molybdenum \\
\hline Mpp & Maximum power point \\
\hline N-type & Negative type material \\
\hline $\mathrm{nm}$ & Nanometer $\left(10^{-9}\right.$ meter $)$ \\
\hline $\mathrm{Pm}$ & pico meter \\
\hline $\mathrm{p}_{\mathrm{m}}$ & Output power of the solar cell \\
\hline $\mathrm{P}_{\text {sun }}$ & incoming power of the sun \\
\hline P-type & positive type material \\
\hline $\mathrm{R}_{\mathrm{s}}$ & Series resistance \\
\hline $\mathrm{R}_{\mathrm{p}}$ & Shunt resistance \\
\hline S & Sulfur \\
\hline $\mathrm{Se}$ & Selenium \\
\hline SEM & Scanning Electron Microscopy \\
\hline $\mathrm{T}$ & Temperature \\
\hline $\mathrm{Tu}$ & Thiourea \\
\hline$\mu \mathrm{m}$ & micro meter $\left(10^{-6}\right.$ meter $)$ \\
\hline $\mathrm{Uv}-\mathrm{Vis}$ & Ultraviolet - Visible \\
\hline $\mathrm{V}$ & Voltage \\
\hline VB & Valence Band \\
\hline $\mathrm{Vm}$ & Maximum Voltage of Cell \\
\hline Voc & Open circuit voltage \\
\hline $\mathrm{W}$ & Watt \\
\hline $\mathrm{XRD}$ & $\mathrm{X}$-ray diffraction \\
\hline $\mathrm{ZnS}$ & zinc sulfide \\
\hline
\end{tabular}




\section{List of figures}

Figure 1.2: historical evaluation of best solar cell conversion efficiency vs. timeline,

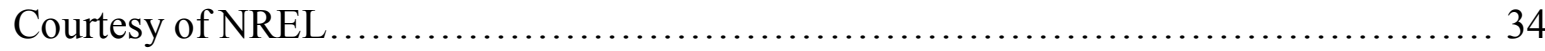

Figure 1.3: Typical CIGS sandwich structure illustration. Devices are deposited on soda lime

glass coated with $1 \mu \mathrm{m}$ thick molybdenum as the back contact. $\sim 2 \mu \mathrm{m}$ thick CIGS absorbers are then deposited using a variety of techniques. A CdS buffer layer with a $\sim 50 \mathrm{~nm}$ thickness is deposited using a CBD technique. The device is finished with a $50 \mu \mathrm{m} \mathrm{ZnO}$ layer deposited by $\mathrm{rf}$ sputtering. Finally $\mathrm{Cu} / \mathrm{Ni} / \mathrm{AI}$ contact grid is added as the top contact using electron

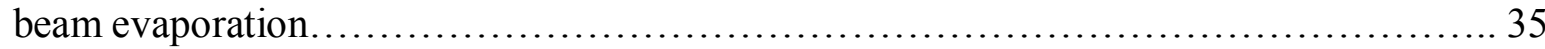

Figure 1.4: Qualitative energy band diagram of $\mathrm{Cu}(\mathrm{In}, \mathrm{Ga}) \mathrm{Se}_{2} / \mathrm{CdS} / \mathrm{ZnO} \ldots \ldots \ldots \ldots \ldots . . . . .37$

Figure 1.5: Comparison of the electron occupancy in allowed energy bands for conductors,

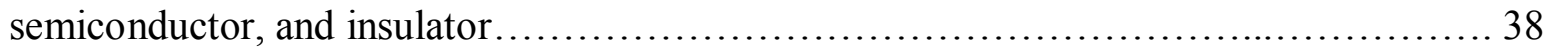

Figure 1.6: Schematic illustration of the formation of an excitation by pairing of electrons in conduction band and positive charged hole in valence band......................... 39

Figure 1.7: - a) Transmission of a photon of energy Ephoton $<$ Eg in a semiconductor material. b) Absorption of a photon of energy Ephoton $=\mathrm{Eg}$ and formation of a pair Electron hole. c) Absorption of a photon of energy Ephoton $>\mathrm{Eg}$, formation of a pair Electron-hole and thermalization of the electron by emission of heat (phonon) $\ldots \ldots \ldots \ldots \ldots \ldots \ldots \ldots \ldots . \ldots \ldots$ Figure 1.8: Energy band diagram for direct and indirect semiconductors. The indirect transition requires assistance of a phonon with energy hv ......................... 41

Figure 2.1: Schematic representation of three-electrode electrochemical cells............ 46

Figure 2.2: process of chemical bath deposition............................... 47

Figure 2.3: schematic diagram of annealing and sulfurization process................ 48

Figure 2.4: Schematic representation of diffraction of X-rays by a crystal (Bragg's

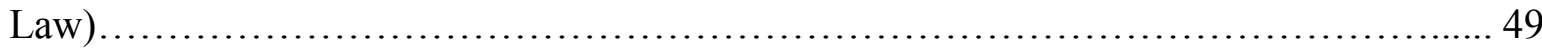

Figure 2.5: image of scanning electron microscopy (FESEM), a Zeiss ULTRA 55 ....... 51

Figure 2.6: image of Bruker Multimode 8 atomic force microscopy (AFM).............. 53

Figure 2.7: image of transmittance electron microscopy (TEM) JEOL JEM 2100F....... 54

Figure 2.8: A schematic diagram of photo electrochemical (PEC) cell................... 56 
Figure 2.9: Example of $\mathrm{J}-\mathrm{V}$ curves for a solar cell in the dark and for the same solar cell under illumination. 58

Figure 3.1: A flowchart of the process used for depositing all samples on different substrates.

Figure 3.2: Cyclic voltammogram of a Mo-coated electrode in three precursor electrolytes: blank solution (dashed line), $4 \times 10-3 \mathrm{~mol} \mathrm{~L}-1 \mathrm{Se}^{4+}, 2 \times 10-3 \mathrm{~mol} \mathrm{~L}^{-1 ~ \mathrm{Cu}^{2+}}$ (red line) and (blue line). $1 \times 10-2 \mathrm{~mol} \mathrm{~L}-1 \mathrm{Ga}^{3+}$. Each solution contains $0.3 \mathrm{~mol} \mathrm{~L}-1 \mathrm{LiCl}_{2}$ as supporting electrolyte and the $\mathrm{pH}$ was adjusted to 2.3 . The sweep rate was $100 \mathrm{mV} \mathrm{s}-1 \ldots \ldots \ldots \ldots . .64$ Figure 3.3: Schematic illustration of a typical temperature profile for the post annealing treatment. 66

Figure 3.4: $\mathrm{XRD}$ patterns of $\mathrm{CuGaSe}_{2}$ and $\mathrm{CuGaS}_{2}$ films: (a) As deposited $\mathrm{CuGaSe}_{2}$ (b) After annealing at $450{ }^{\circ} \mathrm{C}$ in forming gas atmosphere and (c) After sulfurization in molecular Sulphur for 10 minutes at $400^{\circ} \mathrm{C}$

Figure 3.5: SEM images of surface morphology of $\mathrm{CuGaSe}_{2}$ and $\mathrm{CuGaS}_{2}$ films deposited on Mo electrodes at -0.6 during 30 min: (a) as-deposited $\mathrm{CuGaSe}_{2}$, (b) $\mathrm{CuGaSe}_{2}$ annealed for 40 min at $450{ }^{\circ} \mathrm{C}$ in forming gas atmosphere, (c) $\mathrm{CuGaS}_{2}$ films obtained after sulfurization of electrodeposited $\mathrm{CuGaSe}_{2}$ films and (d) $\mathrm{CuGaS}_{2}$ doped with $\mathrm{Cr} \ldots \ldots \ldots \ldots \ldots \ldots \ldots \ldots \ldots$ Figure 3.6: EDS spectrum for: a) annealed $\mathrm{CuGaSe}_{2}$ b) $\mathrm{CuGaSe}_{2}$ doped by $\mathrm{Cr}$ : and c) sulfurized $\mathrm{CuGaS}_{2}$ thin films 73

Figure 3.7: 3D AFM micrograph of as-deposited $\mathrm{CuGaSe}_{2}$ layers (a) as deposited (b), annealed in selenium and (c) sulfurized. 74

Figure 3.8: 2D AFM micrograph of as-deposited $\mathrm{CuGaSe}_{2}$ layers (a) as deposited (b), annealed in selenium and (c) sulfurized......................................... 75

Figure 3.9: Plot of ( $\alpha$ hv) 2 vs. Photon energy for $\mathrm{CuGaSe}_{2}$ and $\mathrm{CuGaS}_{2}$ thin films....... 75 Figure 3.10: Comparison of the absorbance of $\mathrm{CuGaSe}_{2}, \mathrm{CuGaS}_{2}$ and $\mathrm{CuGaS}_{2}: \mathrm{Cr}$ thin films. The broad absorption band observed for $\mathrm{CuGaS}_{2}: \mathrm{Cr}$, centred at $760 \mathrm{~nm}$ is attributed to $\mathrm{Cr}-$ related intermediate band. ................................................... 78

Figure 4.1: X-ray diffraction spectra of as-grown and annealed $\mathrm{CdS}$ and $\mathrm{CdZnS}$ thin films for different $\mathrm{Zn}$ content $3 \%, 5 \%$ and $10 \%$, respectively........................... 86

Figure 4.2: Top view SEM images of CdZnS thin films prepared with different amounts of Zn: (a) $0 \%$, (b) $3 \%$, (c) 5\%, and (d) $10 \%$ 88 
Figure 4.3: AFM micrograph of $\mathrm{CdZnS}$ with different amounts of $\mathrm{Zn}$ : (a) 0 at \%, (b) 3 at \%, (c) 5 at $\%$, and (d) 10 at $\%$ content. 89

Figure 4.4: top view TEM images of CdS films ................................. 90

Figure 4.5: (a) Top view TEM image of CdZnS thin films (b,c) HRTEM image of nano wire of $\mathrm{ZnCdS}$ with different nano scale..... 91

Figure 4.6: TEM images of $\mathrm{CdZnS}$ composite and elemental maps for each constituent element. 91

Figure 4.7: Optical transmittance for $\mathrm{CdZnS}$ with different $\mathrm{Zn}$ content. 92

Figure 4.8: Plot of (Ahv)2 versus the photon energy (hv) for $\mathrm{CdZnS}$ thin films with different Zn concentrations 93

Figure 4.9: Time-based photocurrent intensities of $\mathrm{CdZnS}$ electrodes measured in $0.1 \mathrm{M}$ KCL electrolyte under a potential of $+0.1 \mathrm{~V}$ in the dark and under illumination. 94

Figure 5.1: $\mathrm{XRD}$ patterns of $\mathrm{CuGaSe}_{2}$ and $\mathrm{CuGaS}_{2}$ films: (a) $\mathrm{CuGaSe}_{2}$ after annealing at 400 ${ }^{\circ} \mathrm{C}$ in forming gas atmosphere, and (b) after sulfurization in molecular sulfur for 10 minutes at $400{ }^{\circ} \mathrm{C}$ .100

Figure 5.2: EDS spectrum for: a) annealed $\mathrm{CuGaSe}_{2}$, b) $\mathrm{CuGaSe}_{2}$ doped with $\mathrm{Cr}$........ 101 Figure 5.3: Comparison of the absorbance of $\mathrm{CuGaSe}_{2}, \mathrm{CuGaS}_{2}$ and $\mathrm{CuGaS}_{2}: \mathrm{Cr}$ thin films. The broad absorption band observed for $\mathrm{CuGaS}_{2}: \mathrm{Cr}$, centered at $760 \mathrm{~nm}$, is attributed to the Cr-related in-gap band.... 103

Figure 5.4: The electronic structure and design of an intermediate band solar cell. 104

Figure 5.5: Illustration of the absorbance spectrum of an intermediate band solar

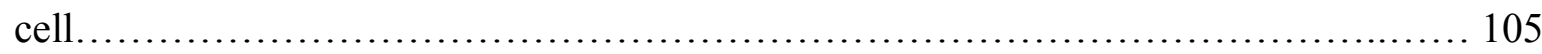

Figure 5.6: Band diagram of the $\mathrm{Mo} / \mathrm{CuGaS} 2 / \mathrm{CdS} / \mathrm{ZnO}$ thin film solar cell............ 106 Figure 5.7: $\mathrm{EQE}$ for $\mathrm{Mo} / \mathrm{CuGaS}_{2}: \mathrm{Cr} / \mathrm{CdS} / \mathrm{ZnO}$ solar cells with different $\mathrm{Cr}$ contents under standard AM1.5 illumination.............................................. 107

Figure 5.8: $\mathrm{J}-\mathrm{V}$ characteristics of $\mathrm{CuGaS}_{2}: \mathrm{Cr}$ thin film solar cells with various $\mathrm{Cr}$ contents. 108

Figure 5.9: J-V characteristics of solar cells based on $\mathrm{CuGaS}_{2}: \mathrm{Cr} 20 \%$ absorbers with different amounts of neutral defects. 109 
This page intentionally left blank 


\section{List of tables}

Table 3.1: Calculated values for the crystallite size of $\mathrm{CuGaSe}_{2}$ and $\mathrm{CuGaS}_{2}$ thin films. Uncertainties appear in parentheses......................................... 70

Table 3.2: EDS analysis of elemental composition of $\mathrm{CuGaSe} 2$ and $\mathrm{CuGaS} 2$ films. EDS

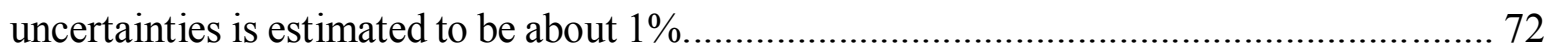

Table 3.3: AFM characterization of $\mathrm{CuGaSe}_{2}$ and $\mathrm{CuGaS}_{2}$ thin films................... 75

Table 4.1: Show the relation between roughness and grain size with different $\mathrm{Zn}$

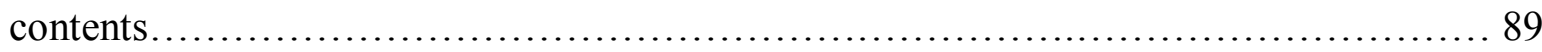

Table 4.2: Elemental Composition obtained from EDS and optical band gap for CdZnS thin films with different $\mathrm{Zn}$ amounts............................................... 93

Table 5.1: Output parameters of the modelled $\mathrm{Mo} / \mathrm{CuGaS} 2: \mathrm{Cr} / \mathrm{CdS} / \mathrm{ZnO}$ thin film solar cell

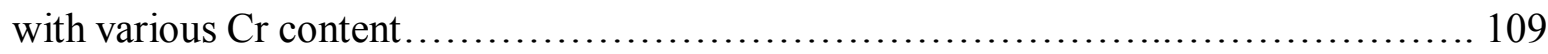

Table 5.2: Output parameters of the modelled $\mathrm{Mo} / \mathrm{CuGaS} 2 \mathrm{Cr} / \mathrm{CdS} / \mathrm{ZnO}$ thin film solar cell

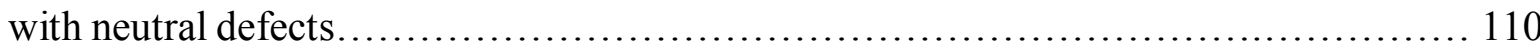


This page intentionally left blank 


\section{ACKNOWLEDGEMENTS}

I owe my profound thanks and deepest gratitude to Almighty ALLAH, Creator of the universe, and worthy of all praises, who blessed me with the potential, ability and determination to complete this research work. This is his extreme blessing on me for which I cannot adequately thank.

I wish to express my heartfelt thanks, respect and admiration to my supervisor, Prof. Dr. Bernabé Marí Soucase, Director, School of Applied physics, and The University of polytechnic of Valencia for accepting me as a research student in his admired research group, his kind supervision and supreme support during the whole course of this study. He is one of the most learned researchers and I really feel proud of being his student, for his support and guidance throughout my $\mathrm{PhD}$ program. Without his vast knowledge and experience with solar cells, the completion of this work would have taken much longer.

I am immensely indebted to Prof. Dr. Miguel Moller, who's always help me in every moment during my experimental and laboratory work without any barrier He is an excellent advisor and a good friend. He provided me the knowledge base for my research activities, enabled me to learn more about this field and provided me the opportunities to collaborate with other researchers.

My sincere appreciation is due to Sponsorship by European Union through its Erasmus Mundus program (IDEAS Innovation and Design for Euro-Asian Scholars) to conduct research for 22 months at Universitat Politechnica de Valencia (UPV) Spain and the UPV Program under Erasmus+ KA107 outgoing for 12 months. This study would not have been possible without these financial support.

This acknowledgment will be incomplete if I do not appreciate with thanks, the moral support and technical help extended by my worthy colleague Dr. Hanif Ullah he has always been a source of motivation during whole course of my research work. Furthermore, I would like to extend my heartiest thank all of my former and present fellows at the Institute of design and fabrication (IDF) research group. Especially, Erika Baiga, Feriel Bouhjar, Zineb Sandra, Suzan Kamal, Bachir Slimi, Nouri Abdelhak, Racha Chaabani, Dr. Thierno Sall, Dr. Oyedele Sampson Oladapo, Lahoucine Atourki, Ahmed Ziti, Samuel Gallego, Ahmed Kotbi, my colleagues from the Universidad Abdelmalek Essaadi tangier (Morocco), Hajar ghanam and 
Imane Barrijal, for all the interactions, scientific, personal and a nice working atmosphere. Their earnest support has been very helpful and they have had a great impact on my research and my life. My work was certainly made better with their consultations. Really I have enjoyed working at laboratory of semiconductor,

I would like to thank Manuel planes head of microscopy and their team specially Alicia Nuez, Mercedes Tabervero, Jose Luis Moya and Joaquin Fayos showing me techniques and giving me helpful advices for SEM, TEM and AFM analysis during my samples characterization throw out my research study.

Last, but certainly not least, Of course the acknowledgement would never be complete without expressing my gratitude my family and their unconditional support has played a key role in my research efforts. I own everything to my parents for teaching me to be sparing, honest, kind, generous, and hardworking, I would not have made it to this point of my life. 
To my beloved family and friends

\section{Dedication}

This thesis is dedicated to those closest to my heart my family. Dr. Hanif Ullah, professors \& teachers, friends \& well-wishers and all who have inspired me to get to where I am today. Thank all of you for the inspiration. 
This page intentionally left blank 


\section{Summary of thesis:}

The improvement of low cost, efficient photovoltaic devices is a leading technological challenge in the recent decade. There is a need to develop scalable and high-throughput manufacturing techniques that could reduce costs and improve manufacturing of chalcogenide solar cells. Copper, indium, gallium, and selenium (CIGS) Thin films polycrystalline heterojunction solar cells appear to be most appropriate with to cost and ease of manufacture.

Currently $\mathrm{Cu}(\mathrm{In}, \mathrm{Ga})\left(\mathrm{Se}, \mathrm{S}_{2}\right.$ materials hold the highest record cell efficiency of $22.3 \%$ in laboratory scale for thin films solar cells and the efficiency still be boosted by improving the different layers of the photovoltaic devices. CIGS chalcogenide absorber layers has been a leading candidate material in photovoltaic devices for thin films solar cells and space applications due to its unique optical-electronic properties as well as its radiation resistance.

In the present work, thin films of $\mathrm{Cu}(\mathrm{In}, \mathrm{Ga})(\mathrm{Se}, \mathrm{S})_{2}$ were deposited at room temperature on glass substrates coated with ITO and Mo by electrodeposition techniques. The obtained polycrystalline thin films were characterized by UV-Vis spectroscopy, X-ray diffraction (XRD), scanning electron microscopy (SEM), atomic force microscopy (AFM), transmission electron microscopy (TEM) and energy dispersive spectroscopy (EDS) analysis.

Thin films of $\mathrm{Cu}$ (In, Ga) (Se, S)2 grown by electrodeposition were subsequently processed into several sets of conditions including vacuum heat treatment, heat treatment in the presence of selenium or sulfur, heat treatment in nitrous gas atmosphere $\left(\mathrm{N}_{2} \mathrm{H}_{2}\right)$ at different temperature and processing times.

To improve the composition and the crystalline structure of the thin layers and to optimize the electro-optical properties a heat treatment of the thin films was developed in two stages after the electrodeposition. It was observed that the first annealing step (heating treatment at $450{ }^{\circ} \mathrm{C}$ in a selenium atmosphere 40 minutes) produced an appreciable improvement in the crystalline structure in the thin layer composition.

In a second stage a sulfurization of the $\mathrm{CuGaSe}_{2}$ films was performed at $400{ }^{\circ} \mathrm{C}$ for $10 \mathrm{~min}$ in the presence of molecular sulfur and under the forming gas atmosphere. The effect of sulfurization was the complete conversion of selenium to sulfur and, therefore, the transformation of $\mathrm{CuGaSe}_{2}$ into $\mathrm{CuGaS}_{2}$.

The formation of $\mathrm{CuGaS}_{2}$ thin films was evidenced by the by the displacement of the diffraction peaks of the $\mathrm{CuGaSe}_{2}$ towards higher angles to which makes the X-Ray diffraction 
pattern which makes it coincide with the diffraction pattern of the $\mathrm{CuGaSe}_{2}$ films, and by the shift towards the blue (higher energies) of the optical gap. The optical gap found for the $\mathrm{CuGaSe}_{2}$ layer was $1.66 \mathrm{eV}$, while the optical gap for the $\mathrm{CuGaS}_{2}$ was raised up to $2.2 \mathrm{eV}$.

CdS thin films have been widely used as buffer layer in CIGS solar cells. However, when alloyed with $\mathrm{Zn}$, ZnCdS can still improve its performance as buffer layer. ZnCdS can be used as buffer and as window material in photoconductive devices and in heterojunction thin film solar cells due the possibility to tune the bandgap with the content of $\mathrm{Zn}$. The band spacing of this ternary material can be from 2.42 to $3.50 \mathrm{eV}$, depending on the $\mathrm{Cd} / \mathrm{Zn}$ ratio.

Finally, the doping of the $\mathrm{CuGaS}_{2}$ layer with chromium was approached to form an intermediate absorption band that allows to absorb photon of energy lower of the gap and to send electrons of the band of valence to the conduction band by absorption of two photons of energy smaller than the gap. For this, various concentrations of $\mathrm{Cr}$ ions were added to the initial electrolyte, $\mathrm{CuGaSe}_{2}: \mathrm{Cr}$ layers were obtained which were transformed into $\mathrm{CuGaS}_{2}: \mathrm{Cr}$ by sulfurization. The films resulting from $\mathrm{CuGaS}_{2}$ : $\mathrm{Cr}$ showed an absorption band located in the semiconductor gap and centred at 1-63 eV which can be attributed to $\mathrm{Cr}$ atoms at $\mathrm{Ga}$ sites. EDX showed that the concentration of $\mathrm{Cr}$ could reach $8 \%$.

Subsequently, a numerical analysis of the properties of solar cells based on intermediate band absorbance layers, such as $\mathrm{CuGaS}_{2}$ : $\mathrm{Cr}$, was carried out using the specific Solar Cell Capacitance Simulator (SCAPS) software. The behaviour of $\mathrm{Mo} / \mathrm{CuGa}_{2} / \mathrm{CdS} / \mathrm{ZnO}$ solar cells was studied and compared to an intermediate band absorber: $\mathrm{Mo} / \mathrm{CuGaS}{ }_{2}: \mathrm{Cr} / \mathrm{CdS} / \mathrm{ZnO}$.

Photovoltaic parameters (open circuit voltage, short-circuit current, fill factor and conversion efficiency) and the efficiency of the analyzed solar cells were obtained through SCAPS. Both the quantum efficiency as the short circuit current and the open circuit voltage of the simulated $\mathrm{Mo} / \mathrm{CuGaS}_{2}: \mathrm{Cr} / \mathrm{CdS} / \mathrm{ZnO}$ solar cells increased proportionally to the amount of $\mathrm{Cr}$ present in the $\mathrm{CuGaS}_{2}: \mathrm{Cr}$.

However, when neutral defects related to Cr-doping were introduced in the absorber layer, the positive effect of the enhancement of photon harvesting due to IGB was compensated by a decline in the carrier collection and the overall efficiency of the device fell considerably 


\section{Resumen en castellano}

La obtención de dispositivos fotovoltaicos más eficientes y de bajo coste es uno de los desafíos tecnológicos más importantes de las últimas décadas. Existe la necesidad de desarrollar técnicas de fabricación escalables y de alto rendimiento que puedan reducir los costos y mejorar la fabricación de células solares de capa fina. Las células solares de heterounión de capas finas de seleniuro (o sulfuro) de cobre, indio y galio (CIGS) parecen estar bien adaptadas lograr este reto debido a su bajo costo, facilidad de fabricación y elevado rendimiento de los dispositivos.

En la actualidad, $\mathrm{Cu}(\mathrm{In}, \mathrm{Ga}) \mathrm{Se}_{2}$ ostenta el record de eficiencia de células solares con 22,3\% a escala de laboratorio y esta eficiencia todavía puede ser acrecentada si se mejoran las diferentes capas de los dispositivos fotovoltaicos. Además, las capas absorbedoras de calcogenuros CIGS son un material candidato importante en dispositivos fotovoltaicos para capas delgadas celdas solares para aplicaciones espaciales debido a sus propiedades electrónicas, así como a su resistencia a la radiación.

En el presente trabajo, las películas delgadas de $\mathrm{Cu}(\mathrm{In}, \mathrm{Ga})(\mathrm{Se}, \mathrm{S})_{2}$ se depositaron a temperatura ambiente sobre sustratos de vidrio recubiertos con ITO y Mo mediante técnicas electroquímicas. Las películas finas policristalinas obtenidas se caracterizaron por espectroscopia óptica UV-Vis, difracción de rayos X (XRD), microscopía electrónica de barrido (SEM), microscopía de fuerza atómica (AFM), microscopía electrónica de transmisión (TEM) y espectroscopia de energía dispersiva (EDS).

Las películas finas de $\mathrm{Cu}(\mathrm{In}, \mathrm{Ga})(\mathrm{Se}, \mathrm{S})_{2}$ crecidas por electrodeposición se procesaron posteriormente en varios conjuntos de condiciones que incluían tratamiento térmico en vacío, tratamiento térmico en presencia de selenio o de azufre, tratamiento térmico en atmósfera gas nidrón $\left(\mathrm{N}_{2} \mathrm{H}_{2}\right)$ a diferentes temperaturas y tiempos de procesado.

Para mejorar la composición y la estructura cristalina de las capas finas y para optimizar las propiedades electro-ópticas se desarrolló un tratamiento térmico de las películas finas en dos etapas posterior a la electrodeposición. Se observó que la primera etapa de recocido (tratamiento térmico a $450^{\circ} \mathrm{C}$ en una atmósfera de selenio durante 40 minutos) producía una mejora apreciable en la estructura cristalina y en la composición de la capa fina. 
En una segunda etapa se realizó una sulfuración de las películas de $\mathrm{CuGaSe}_{2}$ se realizó a 400 ${ }^{\circ} \mathrm{C}$ durante $10 \mathrm{~min}$ en presencia de azufre molecular y bajo la atmósfera reductora de gas nidrón. El efecto de la sulfuración fue la completa conversión del selenio en azufre y, por tanto, la transformación de $\mathrm{CuGaSe}_{2}$ en $\mathrm{CuGaS}_{2}$.

La formación de películas delgadas de $\mathrm{CuGaS}_{2}$ se evidenció por el desplazamiento de los picos de difracción de las capas de $\mathrm{CuGaSe}_{2}$ hacia ángulos más altos hasta lo que hace que el patrón de difracción de rayos $\mathrm{X}$ lo que hace que coincida con el patrón de difracción del $\mathrm{CuGaS}_{2}$ y por el desplazamiento hacia el azul (energías más altas) del gap óptico. El gap óptico encontrado para las capas de $\mathrm{CuGaSe}_{2}$ era de $1,66 \mathrm{eV}$, mientras que el gap óptico para las capas de $\mathrm{CuGaS}_{2}$ se elevó hasta 2,2 eV.

Las películas delgadas de CdS se han utilizado ampliamente como capa tampón en células solares CIGS. Sin embargo, cuando se alea con Zn, para formar el ternario ZnCdS, todavía puede mejorar su rendimiento como capa buffer. $\mathrm{ZnCdS}$ puede utilizarse como tampón y como ventana óptica en dispositivos fotoconductores y en células solares de capa fina de heterounión debido a la posibilidad de ajustar el bandgap con el contenido de $\mathrm{Zn}$. La separación entre bandas de este material ternario puede oscilar entre 2,42 a 3,50 eV, dependiendo de la relación $\mathrm{Cd} / \mathrm{Zn}$.

Por último, se abordó el dopado de las capas de $\mathrm{CuGaS}_{2}$ con cromo para formar una banda de absorción intermedia que permita absorber fotones de energía menor del gap y enviar electrones de la banda de valencia a la banda de conducción por absorción de dos fotones de energía menores que el gap. Para ello se añadieron diversas concentraciones de iones $\mathrm{Cr}$ al electrólito inicial, se obtuvieron capas de $\mathrm{CuGaSe}_{2}: \mathrm{Cr}$ que fueron transformadas en $\mathrm{CuGaS}_{2}: \mathrm{Cr}$ por sulfurización. Las películas resultantes de $\mathrm{CuGaS}_{2}: \mathrm{Cr}$ mostraban una banda de absorción localizada en el gap del semiconductor y centrada a 1,63 eV que se puede atribuir a átomos de $\mathrm{Cr}$ en sitios Ga. Mediante EDX se constató que la concentración de $\mathrm{Cr}$ podía alcanzar el $8 \%$.

Posteriormente se realizó un análisis numérico de las propiedades de células solares basadas en capas absorbentes de banda intermedia, como el $\mathrm{CuGaS}_{2}: \mathrm{Cr}$, mediante el software específico denominado SCAPS. Se estudió el comportamiento de células solares de $\mathrm{Mo} /$ 
$\mathrm{CuGaS}_{2} / \mathrm{CdS} / \mathrm{ZnO}$ y se comparó con una absorbente de banda intermedia: $\mathrm{Mo} / \mathrm{CuGaS}_{2}: \mathrm{Cr} / \mathrm{CdS} / \mathrm{ZnO}$.

Mediante SCAPS se obtuvieron los parámetros fotovoltaicos (tensión en circuito abierto, corriente en corto circuito, factor de llenado y eficiencia de conversión) así como la eficiencia de las células solares analizadas. Tanto la eficiencia cuántica como la corriente de cortocircuito y la tensión en circuito abierto de las células solares $\mathrm{Mo} / \mathrm{CuGaS} 2: \mathrm{Cr} / \mathrm{CdS} / \mathrm{ZnO}$ simuladas aumentaron proporcionalmente a la cantidad de $\mathrm{Cr}$ presente en los absorbedores de $\mathrm{CuGaS}_{2}$ :Cr. Como resultado, la eficiencia de conversión de los dispositivos fotovoltaicos simulados pasó de $14,7 \%$ para $\mathrm{CuGaS}_{2}$ a $34 \%$ para $\mathrm{CuGaS}_{2}: \mathrm{Cr}$.

Sin embargo, cuando se introdujeron defectos neutros relacionados con el dopaje con $\mathrm{Cr}$ en la capa absorbente, el efecto positivo de la mejora de la recolección de fotones debido al efecto de la banda intermedia se compensó con una disminución en la extracción de los portadores y la eficiencia global del dispositivo disminuyó en una relación inversamente proporcional a la concentración de defectos. 
This page intentionally left blank 


\section{Resum en valencià}

L'obtenció de dispositius fotovoltaics més eficients i més barats és un dels reptes tecnològics més importants de les últimes dècades. Hi ha la necessitat de desenvolupar tècniques de fabricació que siguen escalables i d'alt rendiment i que permeten reduir els costos de fabricació i millorar el rendiment de les cèl·lules solars de capa fina. Les cèlllules solars de heterounió de capes fines de seleniur (o sulfur) de coure, indi i gal·li (CIGS) semblen estar ben adaptades per assolir aquest repte degut a del seu baix cost, facilitat de fabricació i elevat rendiment dels dispositius.

En l'actualitat, el $\mathrm{Cu}(\mathrm{In}, \mathrm{Ga}) \mathrm{Se}_{2}$ ostenta el rècord d'eficiència de cèl·lules solars amb 22,3\% a escala de laboratori i aquesta eficiència encara pot ser augmentada si es milloren les característiques de les diferents capes dels dispositius fotovoltaics. Les capes absorbidores de calcogenurs CIGS són un candidat important per dispositius fotovoltaics per a pel·lícules primes en cel·les solars i aplicacions espacialles degut a les seues propietats electròniques així com a la seua resistència a la radiació.

En el present treball, les pel-lícules primes de $\mathrm{Cu}(\mathrm{In}, \mathrm{Ga})(\mathrm{Se}, \mathrm{S})_{2}$ es van dipositar a temperatura ambient sobre substrats de vidre recoberts amb ITO i Mo mitjançant tècniques electroquímiques. Les pel-lícules fines policristal-lines obtingudes es van caracteritzar per espectroscòpia òptica UV-Vis, difracció de raigs X (XRD), microscòpia electrònica de rastreig (SEM), microscòpia de força atòmica (AFM), microscòpia electrònica de transmissió (TEM) i espectroscòpia d'energia dispersiva (EDS).

Les pel·lícules fines de $\mathrm{Cu}(\mathrm{In}, \mathrm{Ga})(\mathrm{Se}, \mathrm{S})_{2}$ crescudes per electrodeposició es van processar posteriorment en diversos conjunts de condicions que incloïen tractament tèrmic en buit, tractament tèrmic en presència de seleni o de sofre, tractament tèrmic en atmosfera reductora de gas nidró $\left(\mathrm{N}_{2} \mathrm{H}_{2}\right)$ a diferents temperatures i temps de processat.

Per millorar la composició i l'estructura cristal-lina de les capes fines i per optimitzar les propietats electro-òptiques es va desenvolupar un tractament tèrmic de les pel·lícules fines en dues etapes posterior a la electrodeposició. Es va observar que la primera etapa de recuit (tractament tèrmic a $450^{\circ} \mathrm{C}$ en una atmosfera de seleni durant 40 minuts) produïa una millora apreciable en l'estructura cristal·lina i en la composició de la capa fina. 
En una segona etapa es va dur a terme una sulfuració de les pel·lícules de $\mathrm{CuGaSe}_{2}$ que es va realitzar a $400{ }^{\circ} \mathrm{C}$ durant $10 \mathrm{~min}$ en presència de sofre molecular i sota l'atmosfera reductora de gas nidró. L'efecte de la sulfuració va ser la completa conversió seleni en sofre i, per tant, la transformació de $\mathrm{CuGaSe}_{2}$ a $\mathrm{CuGaS}_{2}$.

La formació de pel·lícules primes de $\mathrm{CuGaS}_{2}$ es va evidenciar pel desplaçament dels pics de difracció de les capes de $\mathrm{CuGaSe}_{2}$ cap angles més alts fins el que fa que el patró de difracció de raigs $\mathrm{X}$ el que fa que coincideixi amb el patró de difracció del $\mathrm{CuGaS}_{2}$ i pel desplaçament cap al blau (energies més altes) del gap òptic. El gap òptic trobat per a les capes de $\mathrm{CuGaSe}_{2}$ era de 1,66 eV, mentre que el gap òptic per a les capes de $\mathrm{CuGaS}_{2}$ es va elevar fins a 2,2 eV. Les pel·lícules primes de CdS s'han utilitzat àmpliament com a capa amortidora en cèl·lules solars de CIGS. No obstant això, quan s'alea amb Zn per formar ZnCdS encara pot millorar el seu rendiment com a capa d'amortiment. ZnCdS pot utilitzar-se com capa tampó i com a finestra òptica en dispositius fotoconductors $\mathrm{i}$ en cèl·lules solars de pel·lícula fina d'heterounió degut a la possibilitat d'ajustar el seu bandgap que depoen del contingut de $\mathrm{Zn}$. El bandgap d'aquest material ternari pot oscil lar entre 2,42 i 3,50 eV, depenent de la relació $\mathrm{Cd} / \mathrm{Zn}$.

Finalment es va abordar el dopat de les capes de $\mathrm{CuGaS}_{2}$ amb crom per formar una banda d'absorció intermèdia que permeta absorbir fotons d'energia menor del gap i enviar electrons de la banda de valència a la banda de conducció per absorció de dos fotons d'energia menors que el gap. Per a això es van afegir diverses concentracions d'ions $\mathrm{Cr}$ a l'electròlit inicial, es van obtenir capes de $\mathrm{CuGaSe}_{2}$ dopat amb crom $\left(\mathrm{CuGaSe}_{2}: \mathrm{Cr}\right)$ que van ser transformades en $\mathrm{CuGaS}_{2}: \mathrm{Cr}$ per sulfurització. Les pel·lícules resultants de $\mathrm{CuGaS}_{2}: \mathrm{Cr}$ mostraren una banda d'absorció localitzada en el gap del semiconductor i centrada a 1,63 eV que es pot atribuir a àtoms de $\mathrm{Cr}$ en llocs Ga. Mitjançant EDX es va constatar que la concentració de Cr podia arribar al $8 \%$.

Posteriorment es va realitzar una anàlisi numèric de les propietats de cèl·lules solars basades en capes absorbents de banda intermèdia, com el $\mathrm{CuGaS}_{2}$ : $\mathrm{Cr}$, mitjançant el programari específic denominat SCAPS. Es va estudiar el comportament de cèl·lules solars de Mo / $\mathrm{CuGaS} 2$ / CdS / ZnO i es va comparar amb una absorbent de banda intermèdia: $\mathrm{Mo} / \mathrm{CuGaS}_{2}$ : $\mathrm{Cr} / \mathrm{CdS} / \mathrm{ZnO}$. 
Mitjançant el software SCAPS es van obtenir els paràmetres fotovoltaics (tensió en circuit obert, corrent en curt circuit, factor d'ompliment i eficiència de conversió) així com l'eficiència quàntica de les cèl·lules solars analitzades. Tant l'eficiència quàntica com el corrent de curtcircuit i la tensió en circuit obert de les cèl·lules solars $\mathrm{Mo} / \mathrm{CuGaS}_{2}: \mathrm{Cr} / \mathrm{CdS} / \mathrm{ZnO}$ simulades van augmentar proporcionalment a la quantitat de $\mathrm{Cr}$ present en els absorbidors de $\mathrm{CuGaS}_{2}: \mathrm{Cr}$. Com a resultat, l'eficiència de conversió dels dispositius fotovoltaics simulats va passar de $14,7 \%$ per al $\mathrm{CuGaS}_{2}$ a $34 \%$ per $\mathrm{CuGaS}_{2}: \mathrm{Cr}$. No obstant això, en introduir defectes neutres relacionats amb el dopatge amb Cr en la capa absorbent, l'efecte positiu de la millora de la recol·lecció de fotons degut a l'efecte de la banda intermèdia es va compensar amb una disminució en l'extracció dels portadors i la eficiència global del dispositiu va disminuir en una relació inversament proporcional a la concentració de defectes. 
This page intentionally left blank 


\section{Chapter 1}

\section{Introduction}

\subsection{Energy}

It is well known that the global energy demand is in apex due to fast growth year by year of industrialization and population. Energy consumption is more in developed countries than in developing or underdeveloped countries [1]. Currently, about $80 \%$ of the world's energy demand is met by burning fossil fuels like coal, oil, natural gas, etc., are fast depleting. Which are fundamentally limited in nature there are no new reserves of oil or coal being created. [2] These fuels produce greenhouse gases upon combustion causing significant environmental pollution and is the primary contributor to global warming and man-made climate change. On the other hand, the emissions of $\mathrm{CO}_{2}$ from fossil fuels, biomass, etc., need to be reduced by adopting somewhat alternative sources, such as renewable energy. The reduction of $\mathrm{CO}_{2}$ in the atmosphere is essential, as global warms due to emission by industries that has an impact on the ozone layer. It is a well-known fact that the ozone layer blocks UV radiation, while the radiation travels from the Sun to the Earth. Therefore, the solar energy is an attractive alternative source, which is inexhaustible and pollution free. The Earth receives an annual energy of $1018 \mathrm{kWh}$ from the Sun, which is about 20.000 times more than the present annual energy consumption of the world. Even if a fraction of this energy is effectively utilized, the energy problems can be mitigated to some extent. However, it is a dilute and intermittent source. As such, solar energy systems generally occupy large areas and need proper energy storage systems. Secondly the Earth receives an average radiation of $5 \mathrm{~h}$ and a half per day or less from the Sun in southern hemisphere of the Earth, whereas it is very less $(0-1.5 \mathrm{~h} /$ day $)$ in the northern hemisphere.

Solar energy is unlimited, non-polluting, and can provide a substantial fraction of the world's energy demand in the near future. The current total final consumption of energy amounts to about 100PWh [3] .Even if this is a huge number, it is small in comparison to the energy arriving on earth by solar irradiation.

\subsubsection{Solar energy}

Solar energy is the most abundant energy resource and it is available for use in its direct (solar radiation) and indirect (wind, biomass, hydro, ocean etc.) forms. About $60 \%$ of the 
total energy emitted by the sun reaches the Earth's surface. Even if only $0.1 \%$ of this energy could be converted at an efficiency of $10 \%$, it would be four times larger than the total world's electricity generating capacity of about $5000 \mathrm{GW}$. A lot of effort is used to find good power sources that have a seemingly endless supply of energy and which do not affect the sustainability of the environment in the long run. The collective name for these types of power sources is renewable energies and they are generally divided into wave, hydro, tidal, wind and solar power. A common denominator for all of the categories is that their energy is provided by the sun either directly as for solar power or indirectly as for the others. The sun itself generates massive amounts of power, $10^{26} \mathrm{~W}$ [4].

The use of solar energy is growing strongly around the world, in part due to the rapidly declining solar panel manufacturing costs. For instance, between 2008-2011 PV capacity has increased in the USA from $1168 \mathrm{MW}$ to $5171 \mathrm{MW}$, and in Germany from $5877 \mathrm{MW}$ to $25039 \mathrm{MW}$. The anticipated changes in national and regional legislation regarding support for renewables is likely to moderate this growth [5]. One way to utilize this resource is by using photovoltaic devices.

\subsection{Photovoltaics}

The sun has always been the main source of energy for life on earth. Solar energy striking the earth surface in one hour is estimated to be more than the total energy consumed on the planet in a year.[6] However, it is only during the last two decades that man has learned to convert solar radiations directly into electrical energy with a reasonable degree of efficiency. Solar power arrives as photons or light particles at the Earth's surface and are normally absorbed or reflected by the surface. Absorbing the light generates heat in the absorbing material and was until the 19th century the only way of converting incident solar light into power.

Photovoltaic devices, in other words solar cells, are devices that convert light into electricity. Solar cell or photovoltaic cell is nothing but $\mathrm{p}-\mathrm{n}$ junction when the photons with energy greater than or equal to the band gap of p-absorber impinge on solar cells, the electrons excite from valence band to conduction band in the absorber. Thus electron-hole pairs are created. The electrons cross barrier from $\mathrm{p}$ - to $\mathrm{n}$ - region and holes from $\mathrm{n}$ - to $\mathrm{p}$ - region in order to release their energy before taking place recombination. In other words the electron-hole pairs. There are several different solar cell techniques but the most established type is the 
solid state semiconductor solar cell. The light absorbing layer in these cells can either be an amorphous, crystalline, or polycrystalline semiconductor. Silicon is the most widely used material for solar cells. Silicon solar cells are together with GaAs cells the most efficient single junction devices [7]. Other material, such as $\mathrm{CdTe}$ and $\mathrm{Cu}(\mathrm{In}, \mathrm{Ga}) \mathrm{Se}_{2}$ (CIGS) have grown in importance during recent years. These materials are mainly deposited as polycrystalline thin-films. One advantage of these materials in comparison to crystalline or polycrystalline silicon is the good light absorption properties which reduces the required layer thickness from about a hundred $\mu \mathrm{m}$ down to only a few $\mu \mathrm{m}$. This makes them potentially cheaper to produce if an efficient fabrication method is applied. Semiconductors have distinct bands of electron states, the so called valence and conduction bands. These are separated by a forbidden gap of energies, the band gap, where, for the ideal crystalline material, no electron states exists. At a temperature of $0 \mathrm{~K}$ states up to the valence band maximum are filled with electrons while the conduction band is empty. At higher temperatures some electrons are thermally excited across the band gap and leave behind holes in the valence band. The electron occupancy of the conduction band at a certain temperature is higher the lower the band gap of a material. The electron and hole occupancies of the bands follow the FermiDirac distribution. This distribution is characterized by the Fermi energy, at which the probability of occupation of a state is one half $[8,9]$.

\subsubsection{Different Generations of (Photovoltaic) Solar Cell Technology}

The development of solar cell technologies has been driven by the objective of making the solar cells cost effective for stand-alone and grid-connected applications. Solar cell technologies are classified into three generations depending upon the emergence. Continuous research is going on each of the three generations however first generation of solar cells is mostly in production representing $>85 \%$ of total solar cell production.

\subsubsection{First PV Generation}

The first recognized observation of the photovoltaic effect was by Edmund Becquerel in 1839 [10]. He accomplished this by illuminating a silver chloride electrode that was immersed in an electrolytic solution. The first predecessor to the modern commercialized Si diode solar cell was not invented until 1953 in Bell Labs by Gerald Person, Fuller, and Chapin [11]. 
Thus, first generation crystalline $\mathrm{Si}$ (c-Si) solar cells were born at an efficiency of 6\% [12]. Growing large crystals of pure silicon is a very difficult and energy-intensive process, which is a major challenge in the reduction of production cost. Another challenge of monocrystalline silicon solar cells is that the efficiency decreases with increasing temperature. Poly-crystalline silicon solar cells are an alternative to mono-crystalline formation. They are formed from multiple silicon crystals in mold reducing the cost along with a reduction in efficiency. The first generation devices attain cost parity with fossil fuel energy generation after a payback period of 5-7 years; however the cost of first generation technology is very unlikely to go down to $1 \$ / \mathrm{kWh}$.

\subsubsection{Second PV Generation}

The Second generation solar cells have been researched to meet the challenges of expense and energy requirements of first generation solar cells. Reducing the amount of material needed will decrease the cost of first generation solar cells. The thin film technologies, amorphous $\mathrm{Si}(\mathrm{a}-\mathrm{Si})$, polycrystalline $\mathrm{CdTe}$, and polycrystalline $\mathrm{Cu}(\mathrm{In}, \mathrm{Ga}) \mathrm{Se}_{2}$ (CIGS), that make up the second generation hierarchy are the best candidates to fit that requirement presently.

Advancement in technologies like chemical vapor deposition, metal organic chemical vapor deposition, molecular beam epitaxy, chemical phase epitaxy, electrochemical deposition, chemical bath deposition (CBD) and pulsed laser deposition etc. has helped in the development of thin film technology. The main difference between first and second generation devices is that the second generation solar cells are formed on thin films of semiconductor formed by any deposition techniques unlike the formation of first generation solar cells from the bulk crystalline silicon material. Second generation solar cells are placed in this category mainly for the industrial needs of quick production and large area at a low cost. The deposited layers are quite thin in comparison to first generation solar cells reducing the fabrication cost. There are mainly three categories of thin film solar cells - amorphous silicon, cadmium telluride or cadmium sulfide (CdTe/CdS) and the chalcopyrite family alloys like copper indium gallium (di) selenide (CIGS). First Solar is a pioneering manufacturer of thin film solar cells made up of CdTe material having the cost of $1 \$ / \mathrm{kWh}$. This is the least expensive solar cell in the market; however there are some concerns about the technology due to the toxicity of the material. CIGS solar cells are yet to become a commercial success. 
The researchers have been able to produce $22.3 \%$ efficiency [13] in the laboratory but mass production of CIGS solar cells is a big challenge. Organic materials also fall in this category as the processing is relatively simple and less expensive; however very low efficiency (1\% $5 \%)$ is the major shortcoming of this technology $[14,15]$.

\subsubsection{Third Generation PV Full Spectrum Utilization}

Solar cell technology seeking to overcome the Shockley-Queisser limit of $31-41 \%$ efficiency is known as third generation photovoltaics [16]. This is based on the theoretical limit of single layer first generation technology. So, even though multilayered solar cell devices such as GaAs and a-Si can be classified as third generation, third generation technology is usually thought of something that goes beyond the silicon/thin film hierarchy of a solar cell, presenting concepts such as multiple electron-hole generation, or employing nanotechnology or organic materials.

First and second generation solar cells has two fundamental limitations. First the photons of energy less than the bandgap of the semiconductor material are not absorbed by the solar cell and secondly even if a photon has energy greater than the bandgap, actually the photons of equal energy of the bandgap are effective for conversion into electricity. These limitations have encouraged the researchers all over to design multijunction PV or tandem PV cells utilizing the entire solar spectrum with different bandgap energy semiconductors. The multijunction device is basically a stack of cells each capturing a different portion of the spectrum. The materials of which the stack of cells are made have different bandgap energies with the topmost cell having the highest bandgap and the bottom cell having the lowest bandgap energy. Higher energy photons are absorbed in the top cell layers and lower energy photons are passed to the bottom cell layers. The most efficient PV devices are made up of this multijunction technology. This technology is currently used for terrestrial purposes only but will be available for commercial applications soon. This technology will address the shortcomings of first and second generation PV technologies [17].

\subsection{Advantages of Photovoltaic thin films Technology}

Photovoltaic thin fils solar cells are the most notable photo-conversion devices and the most emerging renewable energy resource for the 21 st century.

1. Generated everywhere, tropical, rural, urban, distributed or grid-feeding mode.

2. Unpolluted technology; do not contribute in environment change or any kind of pollution. 
3. Fuel source is enormous, easily available and immeasurable.

4. Proximity to demand, no transmission cost, can be used for stand-alone and grid connected applications.

5. High reliability of solar cell modules (manufacturers guarantee over 25 years).

6. No emissions, burning or nuclear waste disposal.

7. Uniquely scalable, can supply power in mill watts to megawatts.

8. Nontoxic (except CdTe), made up of thin semiconductor wafers or films.

9. No moving parts (wear and tear) and silent operation

10. Easily assimilated in new or existing building structures.

11. Rapid installation

\subsection{Thin-film Solar Cells technology}

One of the scientific discoveries of the computer semiconductor industry that has shown great potential for the PV industry is thin-film technology. Thin films are exceedingly fine layers of semiconductors placed on top of each other. Thin-film cells can be made from a variety of materials. Today, the most widely used commercial thin-film cells are made from amorphous silicon. Two other materials that are on the verge of commercialization, showing great promise for low cost production, are polycrystalline copper indium diselenide (CIS), copper indium gallium diselenide (CIGS) and cadmium telluride (CdTe). Thin-film devices require very little material and have the added advantage of being easy to manufacture. For cost-per-watt point of view, the choice of any given technology is governed by the highest achievable efficiency, ease of manufacturing, reliability, availability of materials, and environmental sensitivity and thus thin-film solar cell technology has immense potential to become economically viable and widely accepted technology of the future. Rather than by growing, slicing, and treating a crystalline ingot, we make them by sequentially depositing thin layers of the required materials. Several different deposition techniques are available, all of them potentially cheaper than the ingot-growth techniques required for crystalline silicon. These deposition processes can easily be scaled up so that the same technique used to make a 2-inch x 2-inch laboratory cell can be used to make a 2-foot x 5-foot module. The layers can be deposited on various low cost substrates. These can be glass or plastic in virtually any shape-even flexible plastic sheets. While single-crystal cells have to be individually interconnected into a module, thin-film devices can be made monolithically (as a single unit). 
Layer upon layer is deposited sequentially on a glass superstrate, from the antireflection coating and conducting oxide, to the semiconductor material, to the back electrical contacts. Individual cells are formed by scoring each layer with a laser beam.

Unlike most single crystal cells, the typical thin-film device does not use a metal grid for the electrical contact. Instead, it uses a thin layer of a transparent conducting oxide. These oxides, such as tin oxide, indium tin oxide, and zinc oxide, are highly transparent and conduct electricity very well. They collect the current effectively from the top of the cell, and losses due to resistance are minimal. A separate antireflection coating may be used to top off the device, or the transparent conducting oxide may serve this function as well.

\section{$1.5 \mathrm{Cu}(\mathrm{In}, \mathrm{Ga}) \mathrm{Se}_{2}$ thin-film solar cells}

Chalcopyrite Copper indium gallium diselenide $\mathrm{Cu}(\ln , \mathrm{Ga}) \mathrm{Se}_{2}$ has an extremely high absorptivity $\left(10^{5} \mathrm{~cm}^{-1}\right)$ at laboratory scale $[18,19]$ Efforts to seek an economical and scalable method for the production of stoichiometric CIGS thin-films have been ongoing to appreciate the commercialization of these devices. Among several techniques, electrodeposition has demonstrated to produce CIGS devices with high efficiency [20] that allows $99 \%$ of the available incident light to be absorbed in the first micron of the material. But that is not the only reason that $\mathrm{Cu}(\mathrm{ln}, \mathrm{Ga}) \mathrm{Se}_{2}$ is attractive for $\mathrm{PV}$ devices.

It also has shown very good stability in outdoor tests, an important criterion for commercialization. They suffer from light induced degradation leading to long term stability issues [21]. The most common material for the window layer in CIGS devices is CdS [22,23] sometimes zinc is added to improve the transparency. Adding small amounts of gallium to the absorbing CIGS layer boosts the band gap of CIGS (from its normal $1.0 \mathrm{eV}$ ), which improves the voltage and therefore the efficiency of the device [24]. The layers of materials

in CIGS cells can be made by several different processes that were developed in the computer-related thin film industry. The CIGS layer itself consists of quaternary compound elements copper, indium, gallium and selenium.

Various methods were used to prepare CIGS thin films such as chemical bath deposition [25], elemental co-evaporation [26], flash evaporation [27], single-source evaporation [28], RF sputtering [29], electrodeposition, etc [30]. Recently, molecular beam epitaxial growth of CIS has been studied [31]. Compared with the other methods, electrodeposition has its 
advantages, such as low cost, high deposition speed and possibility of large-area polycrystalline films. Electrodeposition has become the focus of many research groups in solar energy cells. To fabricate solar cell modules at a truly competitive cost, the electrodeposition is the most attractive process to cut down the expense.

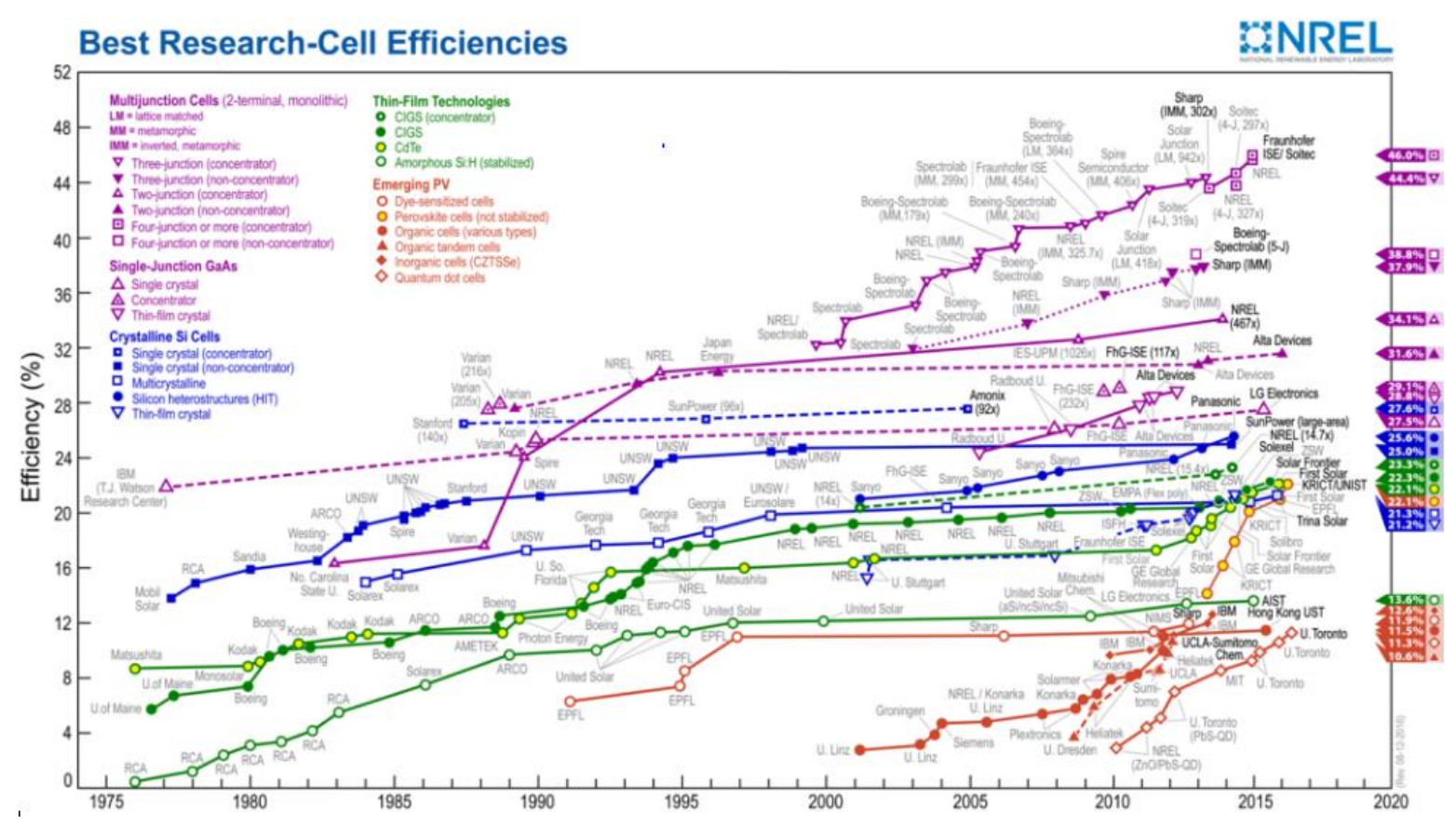

Figure 1.2: historical evaluation of best solar cell conversion efficiency vs. timeline, Courtesy of NREL

\section{6 physics of solar cells}

Air mass (AM) is the measure of how absorption in the atmosphere affects the spectral content and intensity of the solar radiation entering the earth. In space the radiation intensity or the solar constant is $1.353 \mathrm{~kW} / \mathrm{m}^{2}$ and is referred to as AM 0 . The absorption of the spectrum increases with the increase in the thickness of the atmospheric layer. For the thickness $1_{\mathrm{o}}$ of the atmosphere, the path length 1 through the atmosphere for radiation from the sun incident at an angle $\theta$ relative to the normal to the earth's surface is given by $1=10 / \cos$ $\theta$,

Where, $\theta=$ angle of incidence, $\theta=0$ if sun is exactly overhead.

The ratio $1 / 10$ is called air mass co-efficient. The performance of solar cells is evaluated at AM 1.5 condition corresponding to the solar constant of $1 \mathrm{~kW} / \mathrm{m}^{2}$. The solar constant on the earth's surface is always lower than that in space due to the spectrum 
absorption by the atmosphere. This absorption is almost entirely caused by gases of low concentration in the infrared region of the solar spectrum, by water vapor $\left(\mathrm{H}_{2} \mathrm{O}\right)$, carbon dioxide $\left(\mathrm{CO}_{2}\right)$, laughing-gas $\left(\mathrm{N}_{2} \mathrm{O}\right)$, methane $\left(\mathrm{CH}_{4}\right)$, fluorinated hydrocarbon, as well as by dust and in ultraviolet region of the spectrum by ozone and oxygen. A simple way of representing Air Mass value at different earth location is given by the simple equation,

$$
\mathrm{AM}=\left(1+(\mathrm{S} / \mathrm{H})^{2}\right)^{1 / 2}
$$

Where, $\mathrm{S}=$ Length of the shadow cast by an object of height $\mathrm{H}$ at that location.

\subsubsection{Fabrication of $\mathrm{Cu}(\mathrm{In}, \mathrm{Ga}) \mathrm{Se} 2$ thin-film solar cells}

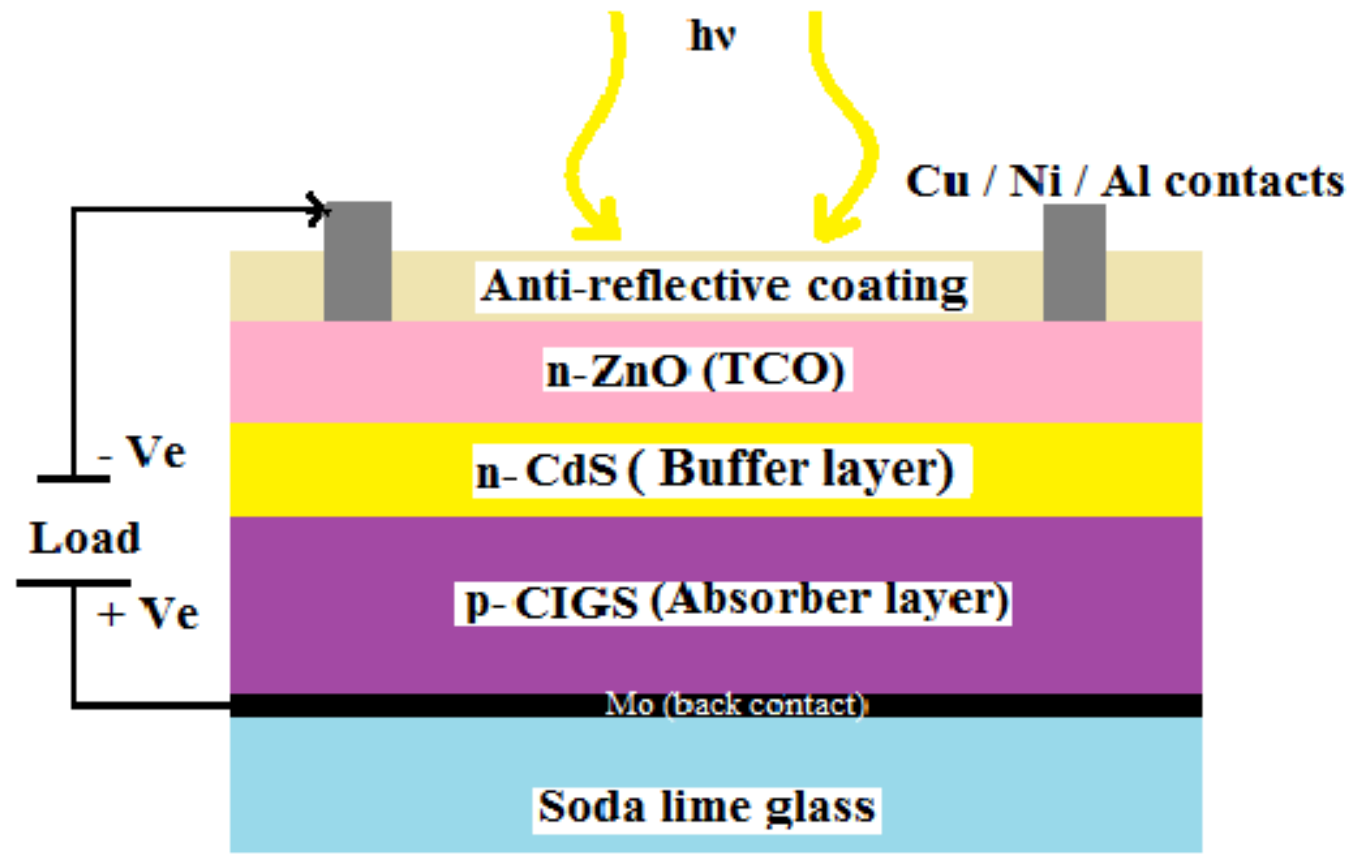

Figure 1.3 Typical CIGS sandwich structure illustration. Devices are deposited on soda lime glass coated with $1 \mu \mathrm{m}$ thick molybdenum as the back contact. $\sim 2 \mu \mathrm{m}$ thick CIGS absorbers are then deposited using a variety of techniques. A CdS buffer layer with a $\sim 50 \mathrm{~nm}$ thickness is deposited using a CBD technique. The device is finished with a $50 \mu \mathrm{m} \mathrm{ZnO}$ layer deposited by $\mathrm{rf}$ sputtering. Finally $\mathrm{Cu} / \mathrm{Ni} / \mathrm{AI}$ contact grid is added as the top contact using electron beam evaporation.

Figure 1.3 shows a CIGS solar cells configuration employ on Molybdenum on a silica-glass substrate and transparent conductive oxides (TCO) deposited by sputtering or chemical vapor deposition serve as back and front contacts, respectively. The heterojunction based on the p-type CIGS absorber and a high bandgap n-type window layer. However, CIGS cells with n-type $\mathrm{ZnO}$ directly deposited onto the p-type CIGS exhibit poor efficiencies. 
Therefore, A thin CdS acts as a suitable candidate buffer layer and plays a key role in the formation of the important heterojunction in CIGS cells, which protects the absorber layer against the chemical reactions and the mechanical damage. The CdS buffer layer helps in widening the depletion layers at the interface allowing a higher open circuit voltage (Voc). It also helps in optimizing the band alignment of the device [32,33] A favorable band alignment to CIGS and to the transparent conductive oxide (TCO) $\mathrm{ZnO}$ is achieved with CdS. Chemical bath deposition is utilized to deposit CdS layers for most of highly efficient CIGS solar cells. In order to maximize the collection of photocurrent generated in the absorber layers and efficiency of the devices, bandgap engineering is usually employed for high efficiency solar cells [34]. The chemical bath removes natural oxides from the absorber surface. More aspects of the heterojunction formation in CIGS-based solar cells and the role of the buffer layer are discussed in refs [35,36,37].

The bandgap is enlarged by higher Ga or Sulphur concentration. The increased bandgap of front surface of CIGS films can reduce the energy loss during thermalization and recombination at CdS/CIGS interface [38] and consequently increase open circuit voltage Voc and energy conversion efficiency. At the back side of CIGS films, the bandgap is increased solely by increasing $\mathrm{Ga} / \mathrm{In}$ ratio. The gradual increase of the conduction-band energy sweeps the photo generated electrons into the direction of $\mathrm{p}-\mathrm{n}$ junction.

\subsubsection{Energy band diagram of $\mathrm{Cu}(\mathrm{In}, \mathrm{Ga}) \mathrm{Se}_{2}$ thin-film solar cells.}

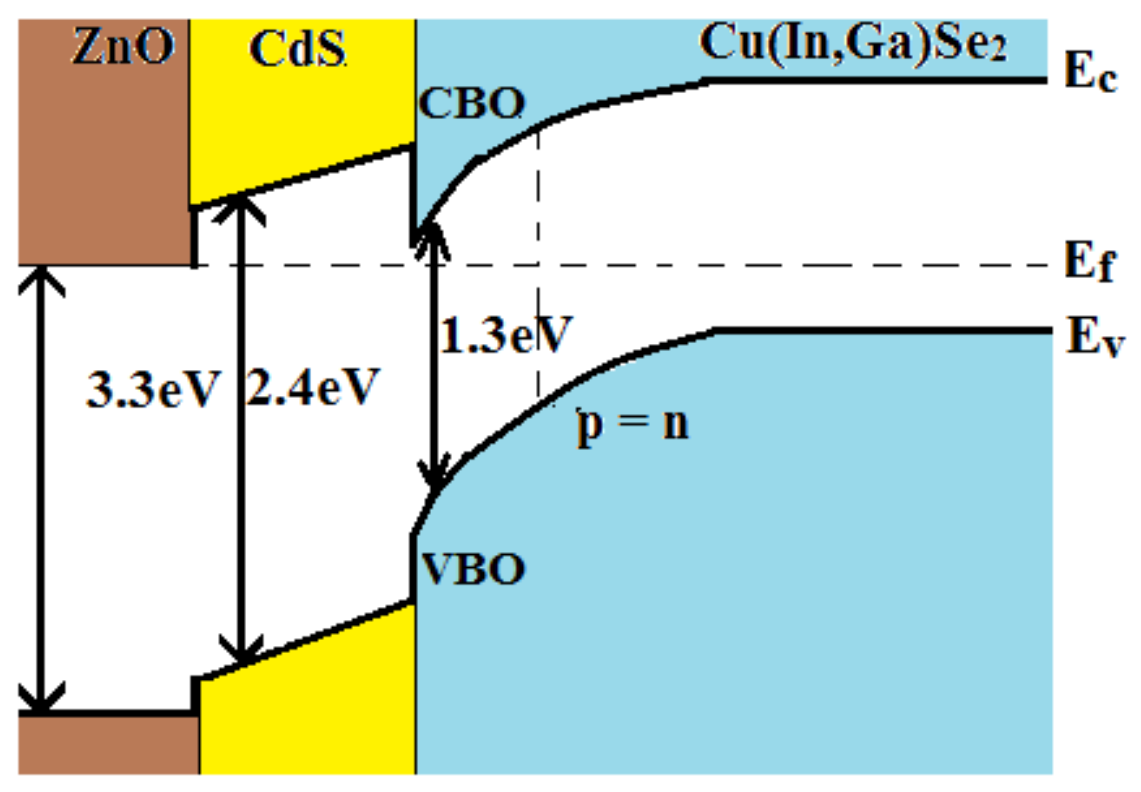


Figure 1.4 Qualitative energy band diagram of $\mathrm{Cu}(\mathrm{In}, \mathrm{Ga}) \mathrm{Se}_{2} / \mathrm{CdS} / \mathrm{ZnO}$

Fig 1.4 show qualitative structure of CIGS solar cell which discuss a major point of interest the small positive CBO between the CIGS and the CdS buffer layer. At a first glance it might not seem beneficial to introduce a barrier for the electrons to overcome as they are driven towards the n-type $\mathrm{ZnO}$ by the electric field in the SCR. However, by analyzing the position of EF another interesting aspect becomes apparent, the electrical p-n junction is pushed into the p-type CIGS, which implies that the topmost part of the CIGS is inverted to n-type. Moving the junction into the CIGS and away from the physical material interface reduces the interface recombination $[39,40]$, since the hole concentration at the interface is reduced. According to a renowned theory [28] it is possible to move the junction into the CIGS by having a zero or a small positive CBO between the absorber and the buffer layer. If the $\mathrm{CBO}$ becomes negative the theory predicts that the junction moves towards the physical material interface and the probability for recombination increases, whereas a too large CBO will reduce the probability that the electrons are able to pass the barrier without providing additional energy. An interesting aspect of CdS that could partially explain its success as buffer layer is that it seems to have a small positive or zero CBO towards

CIGS with a composition corresponding to an x-value of 0.3 [41,42]. Since only Ec moves as the band gap or X-value of CIGS changes [43] it is not possible for CdS to maintain a favorable CBO towards the CIGS for all $\mathrm{x}$-values and this might partly explain why neither solar cells with $\mathrm{x}=0$ or $\mathrm{x}=1$ achieve the same performance as for $\mathrm{x}=0.3$. Interestingly enough CIGS also seem to have the best material properties at $\mathrm{x}=0.3[32,44]$.

\subsection{Electronic properties of material.}

The electronic structure of conductors, semiconductors and insulators are schematically illustrated in Figure 1.5. In conductor's materials, the valence band (VB) overlap the conduction band (CB) and are able to move freely under the influence of an electric field. Electrons can be electrically or thermally excited, so the electrical conductivity is above zero. In contrast, in semiconductors there are small band gaps of $0.5-3.0 \mathrm{eV}$ between the full VB and the empty CB. Neither filled nor empty bands contribute to the electrical conductivity of materials, because electrons cannot gain energy, since all energy levels are filled. The manner 
in which electrons jump from valence band to conduction band depends on the size of the band gap.

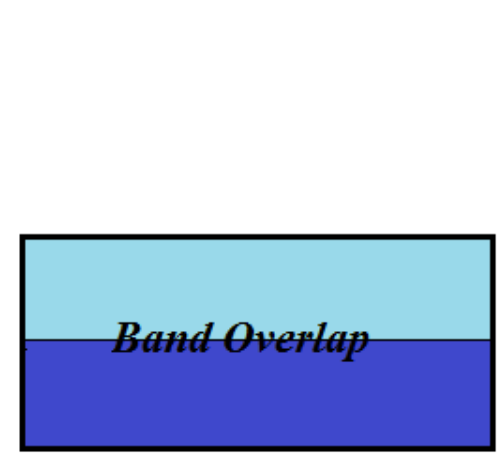

Conductors

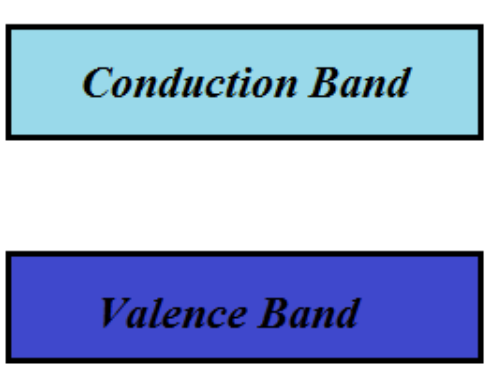

Semiconductors

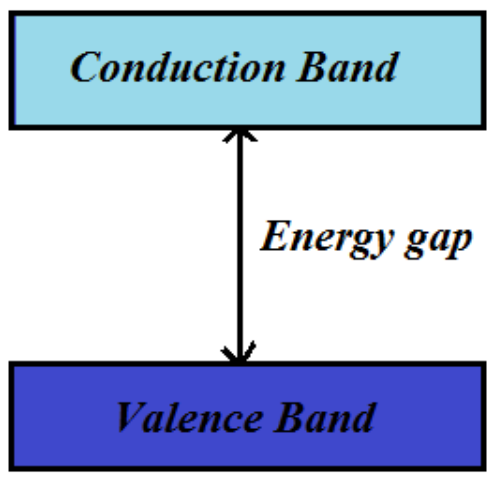

Insulators

Figure 1.5: Comparison of the electron occupancy in allowed energy bands for conductors, semiconductor, and insulator.

When electrons are excited from valence band to conduction band a positively charged hole is left in valence band. If a hole in valence band is caused by impurities, the material is an extrinsic semiconductor (Figure 1.6).

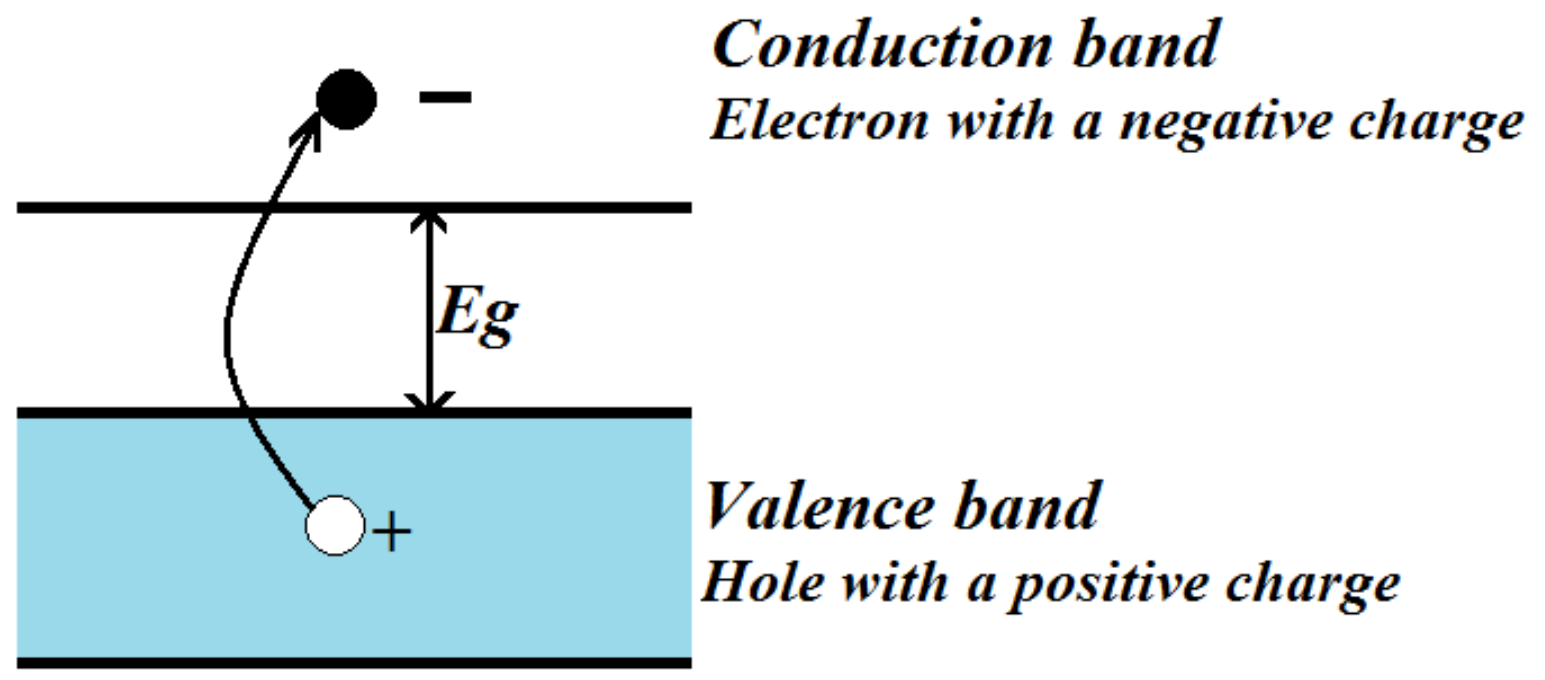

Figure 1.6: Schematic illustration of the formation of an excitation by pairing of electrons in conduction band and positive charged hole in valence band. 
Both the half empty valence band and half-filled conduction band lead to the conductivity of semiconductors, which distinguishes them from metals. Only electrons contribute to the conductivity of metal, while holes and electrons lead to conductivity of semiconductors. As the size of semiconductor nanoparticles decreases, the energy levels in the valence band become discontinuous at band edge, generates an increase in the band gap $[45,46]$. In insulators, the valence band is full of electrons and conduction band is empty of electrons. The energy to excite the electrons from full band to empty one is high, so the electrons cannot be excited from valence band to conduction band. In this respect, the difference between an insulator and a semiconductor is the magnitude of energy gap.

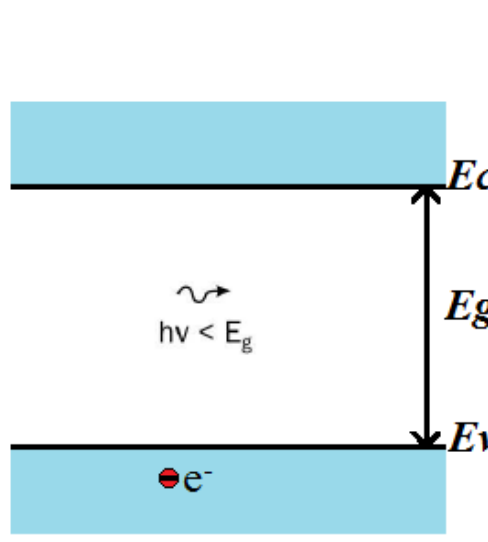

(a)

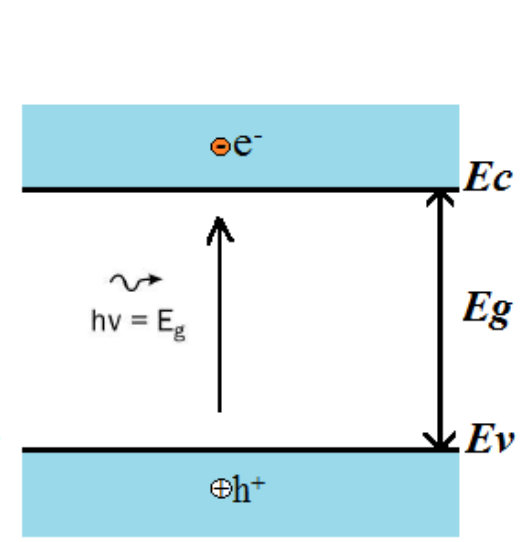

(b)

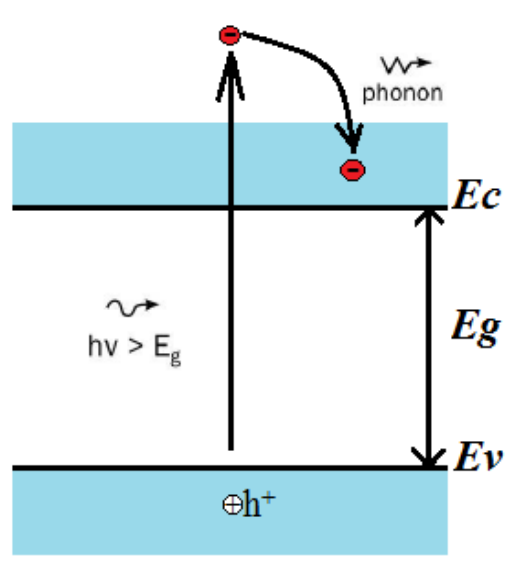

(c)

Figure 1.7 - a) Transmission of a photon of energy $E_{\text {photon }}<$ Eg in a semiconductor material. b) Absorption of a photon of energy $\mathrm{E}_{\text {photon }}=\mathrm{Eg}$ and formation of a pair Electron hole. c) Absorption of a photon of energy $E_{\text {photon }}>\mathrm{Eg}$, formation of a pair Electron-hole and thermalization of the electron by emission of heat (phonon).

\subsection{Direct and indirect bandgap semiconductors}

An important factor determining the efficiency of absorption of light photons in a semiconductor absorber and electron-hole pair's generation is known as the absorption coefficient. When transitions of electrons from the valence band to the conduction band occur in semiconductors, a change in crystal momentum ( $\mathrm{k}$, wave vector) may or may not occur. This occurrence of change in $\mathrm{k}$, wave vector depends on the possible route available involving lowest energy transition. In a typical absorption process, an electron is excited from the valence band to the conduction band upon absorption of a photon. This absorption process occurs with conservation of both the energy and the momentum. The momentum of photon 
being so small in comparison with the momentum of crystal, electron's momentum should essentially be conserved in the absorption process. If the minima of the conduction band and the maxima of the valence band occur at the same value of the wave vector $\mathrm{k}$ (Figure $1.8 \mathrm{a}$ ) in a transition, such transitions are called direct transitions, and the material is termed a direct band gap semiconductor.

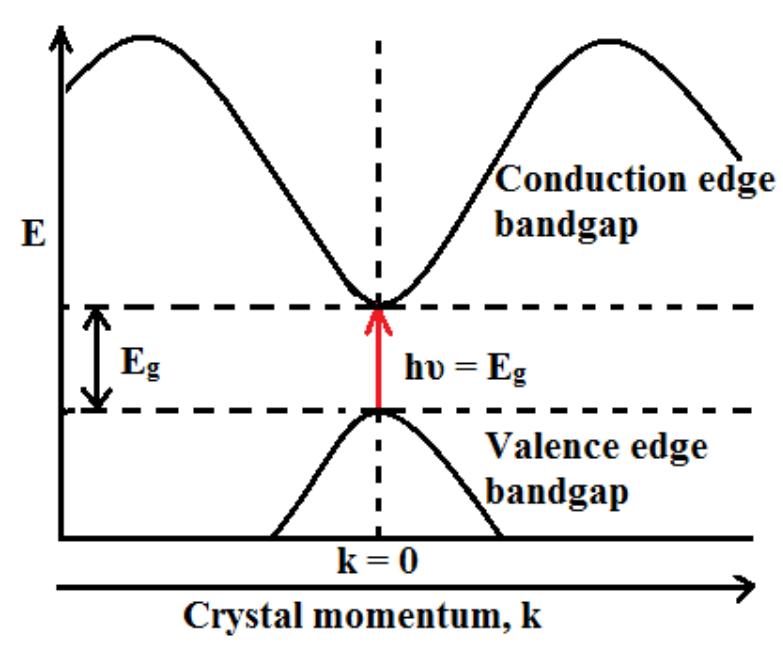

(a) Direct bandgap semiconduction (e. g. InAs and GaAs)

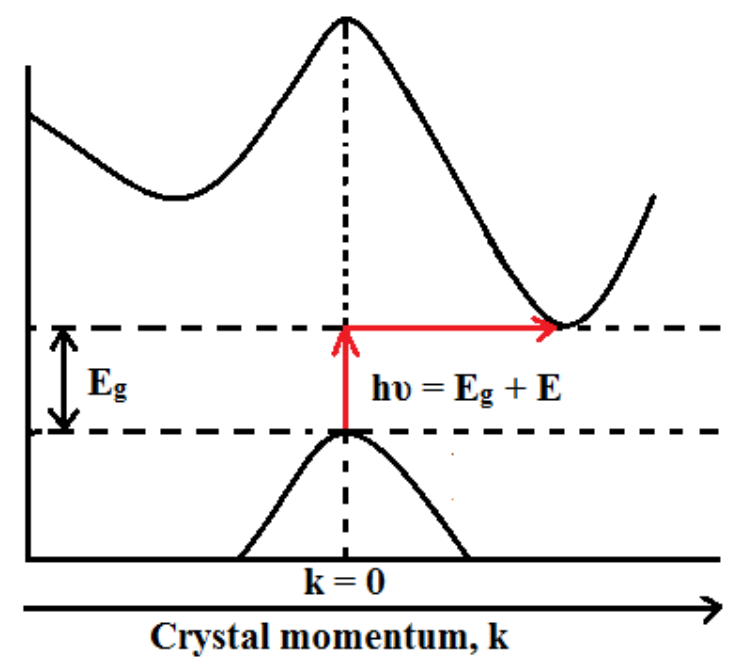

(b) Indirect bandgap semiconduction (e. g. Ge and Si)

Figure 1.8 Energy band diagram for direct and indirect semiconductors. The indirect transition requires assistance of a phonon with energy hv.

Transitions are referred to as indirect transitions if they involve a situation in which band extrema occur at different values of wave vector k, (Figure $1.8 \mathrm{~b}$ ) and accordingly the material is referred to as an indirect band gap semiconductor. Another particle i.e. a phonon is necessary for momentum conservation in such transitions. As compared to direct transitions, the probability for indirect transitions is substantially lower. Therefore, relatively weaker fundamental absorption generally occurs in indirect band gap materials as compared to direct band gap materials. This means that before absorption, a photon is required to travel a long distance into the material thereby limiting the chances of such transitions. Therefore, direct band gap materials have much higher probability of the absorption of photons and therefore possess higher absorption coefficients than indirect band gap materials [47] Direct 
transitions, may have values of absorption coefficients varying from $10^{4}$ to $10^{5} \mathrm{~cm}^{-1}$ while the same may vary from 10 to $10^{3} \mathrm{~cm}^{-1}$ for indirect transitions.

\subsection{Thesis objectives and organization}

The core objective of this research is to establish a new deposition procedure for the fabrication of high efficiency $\mathrm{Cu}(\mathrm{In}, \mathrm{Ga}) \mathrm{Se}_{2}$ thin film solar cell. The high performance $\mathrm{Cu}(\mathrm{In}, \mathrm{Ga}) \mathrm{Se}_{2}$ solar cell results so far have been reported on $\mathrm{Cu}(\mathrm{In}, \mathrm{Ga}) \mathrm{Se}_{2}$ layers prepared by different techniques like, spray-deposition [48], low-temperature deposition. [49] by thermal co-evaporation onto heated substrates $\left(400-600 \mathrm{C}^{\circ}\right)$ [50] or by salinization processes. However, these deposition techniques can be improved for industrial applications, since they are rather difficult to scale-up or are using highly toxic gas. It is thus of interest to develop an alternative, competitive technique that would be even more readily applied by industry. Deposition is a very promising technique for thin film growth. It offers flexibility to control the film stoichiometry and thickness over a large scale at relatively low cost. Thus, the development of an approach called Electrochemical deposition for the device-quality $\mathrm{Cu}(\mathrm{In}, \mathrm{Ga}) \mathrm{Se}_{2}$ absorber layers and $\mathrm{ZnCdS}$ window layers prepared by Chemical bath deposition (CBD) for solar cell application constitutes a main goal of this thesis. For high efficiency devices, transport of the photo generated carriers through the entire solar cell stack is just as important as their generation guaranteed by the device- quality semiconductor $\mathrm{Cu}(\mathrm{In}, \mathrm{Ga}) \mathrm{Se}_{2}, \mathrm{Cu}(\mathrm{In}, \mathrm{Ga}) \mathrm{S}_{2}$ absorber layer. To achieve this goal, it is essential to optimize the back contact layer properties in the solar cell stack. Molybdenum thin films are studied as a back electrode material in $\mathrm{Cu}(\mathrm{In}, \mathrm{Ga}) \mathrm{Se}_{2}$ thin film solar cells. Furthermore, occurrence of undesirable secondary phases during the growth of $\mathrm{Cu}(\mathrm{In}, \mathrm{Ga}) \mathrm{Se}_{2}$ are known to adversely affect the solar cell device. One of the phases, which usually occurs during the deposition of $\mathrm{Cu}(\mathrm{In}, \mathrm{Ga}) \mathrm{Se}_{2}$ thin films, is a conductive $\mathrm{Cu}_{2}$-xSe layer, which particularly lies between the grain boundaries of the $\mathrm{Cu}(\mathrm{In}, \mathrm{Ga}) \mathrm{Se}_{2}$ layer. This phase plays a vital role in the formation of high quality devices if it is formed at the initial state of the $\mathrm{Cu}(\mathrm{In}, \mathrm{Ga}) \mathrm{Se}_{2}$ growth. However, if found in the final $\mathrm{Cu}(\mathrm{In}, \mathrm{Ga}) \mathrm{Se}_{2}$ composition, it usually shorts the device. Our interest in studying $\mathrm{Cu}_{2}-\mathrm{xSe}$ is to use in-situ and real time optical probes to better understand the multistep $\mathrm{Cu}(\mathrm{In}, \mathrm{Ga}) \mathrm{Se}_{2}$ fabrication processes. 
Chapter 2 introduces the fundamental experimental techniques and different characterization which are used to describe solar cell operations and defines their performance characteristics. A brief discussion of $\mathrm{J}-\mathrm{V}$ curves for a solar cell in the dark and for the same solar cell under illumination.

Chapters 3 present the preparation and electrodeposition of $\mathrm{Cu}(\mathrm{In}, \mathrm{Ga}) \mathrm{Se}_{2}$ comprehensive and corroborative studies using of molybdenum back contacts, which have been used in $\mathrm{Cu}(\mathrm{In}, \mathrm{Ga}) \mathrm{Se}_{2}$ solar cells.

Chapters 4 will focus on $\mathrm{Cr}$ doped to create an in band with in the $\mathrm{Cu}(\mathrm{In}, \mathrm{Ga}) \mathrm{Se}_{2}$ thin films and sulfurization process of the as deposited $\mathrm{Cu}(\mathrm{In}, \mathrm{Ga}) \mathrm{Se}_{2}$ thin films. Simulation study of Cr deferent concentration by using SCAP simulation software.

Chapters $5 \mathrm{Zn}$ doped with $\mathrm{CdS}$ by using chemical bath deposition technique, discusses the effect of $\mathrm{Zn}$ content on the properties of thin films. The film's characteristics are compared with respect to the different $\mathrm{Zn}$ concentration

Chapter 6 summarizes the work presented here and the overall, additionally possible future guidelines in applying the research capabilities and building from the significant results described in this dissertation. 
This page intentionally left blank 


\section{Chapter 2}

\section{Experimental, Techniques and Characterization}

\subsection{Electrodeposition}

Electrodeposition, known commercially for use in electroplating, deposits individual species from solution. With careful control of the electron flow, the weight of material deposited can be measured in accordance with Faraday's Law of Electrolysis [51]. In electroplating a metallic coating is electrodeposited on the cathode of an electrolytic cell consisting of a positive electrode (anode), a negative electrode (cathode), and an electrolyte solution (containing the metal ions) through which electric current flows. Important electroplating variables include current efficiency, current density, current distribution, $\mathrm{pH}$, temperature, agitation, and solution composition. A typical electroplating process consist with the following three types of electrode and electrolyte (figure 2.1).

Auxiliary (Counter) Electrode (CE): electrode that helps pass the current flowing through the cell; the current travels between the WE and CE; typically no processes of interest (under study) occur at the surface of CE; example: Pt wire.

Reference Electrode (RE): electrode that can maintain a constant potential under changing experimental conditions; the WE potential is referenced vs. the RE potential; REs are typically anodes in electrochemical cells; example: NHE.

Working Electrode (WE)/Indicator Electrode: electrode where the redox processes under study occur; WEs are typically cathodes; example: ion-selective electrode or noble metal. Supporting Electrolyte: an ionic substance (typically a salt) that is present in a solution to ensure its conductivity; example: $\mathrm{KCl}$. The supporting electrolyte reduces the migration effects in the solution; it does not undergo redox chemistry, and thus its ions are called spectator ions. Sometimes the supporting electrolyte is referred to simply as the electrolyte. 


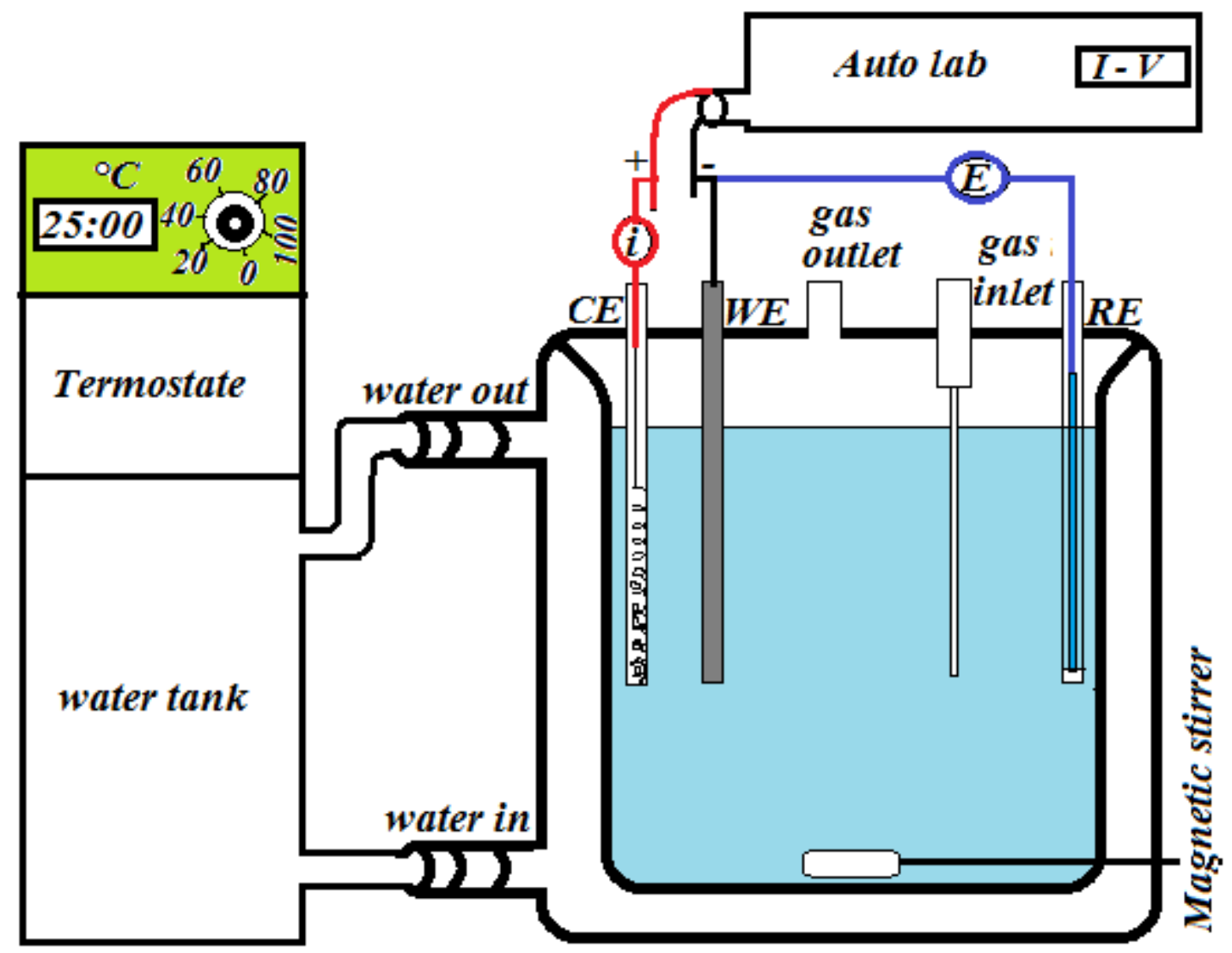

Figure 2.1 Schematic representation of three-electrode electrochemical cells.

\subsection{Chemical Bath Deposition (CBD)}

The CBD method is one of the simplest, economical, low-temperature, and inexpensive large-area batch processing deposition technique to deposit thin films and nanomaterials. The process was first developed in 1933 by Bruckman when he deposited lead (II) sulfide $(\mathrm{PbS})$ thin films. This method requires only solution containers and substrate mounting devices (see figure 2.2). Among various deposition techniques, CBD yields stable, adherent, uniform, and hard films with good reproducibility by a relatively simple process. In this method, thin films of metal chalcogenide materials can be grown on a substrate immersed in an aqueous bath containing appropriate reagents at temperatures ranging from $25^{\circ} \mathrm{C}$ to $100^{\circ} \mathrm{C}$. 


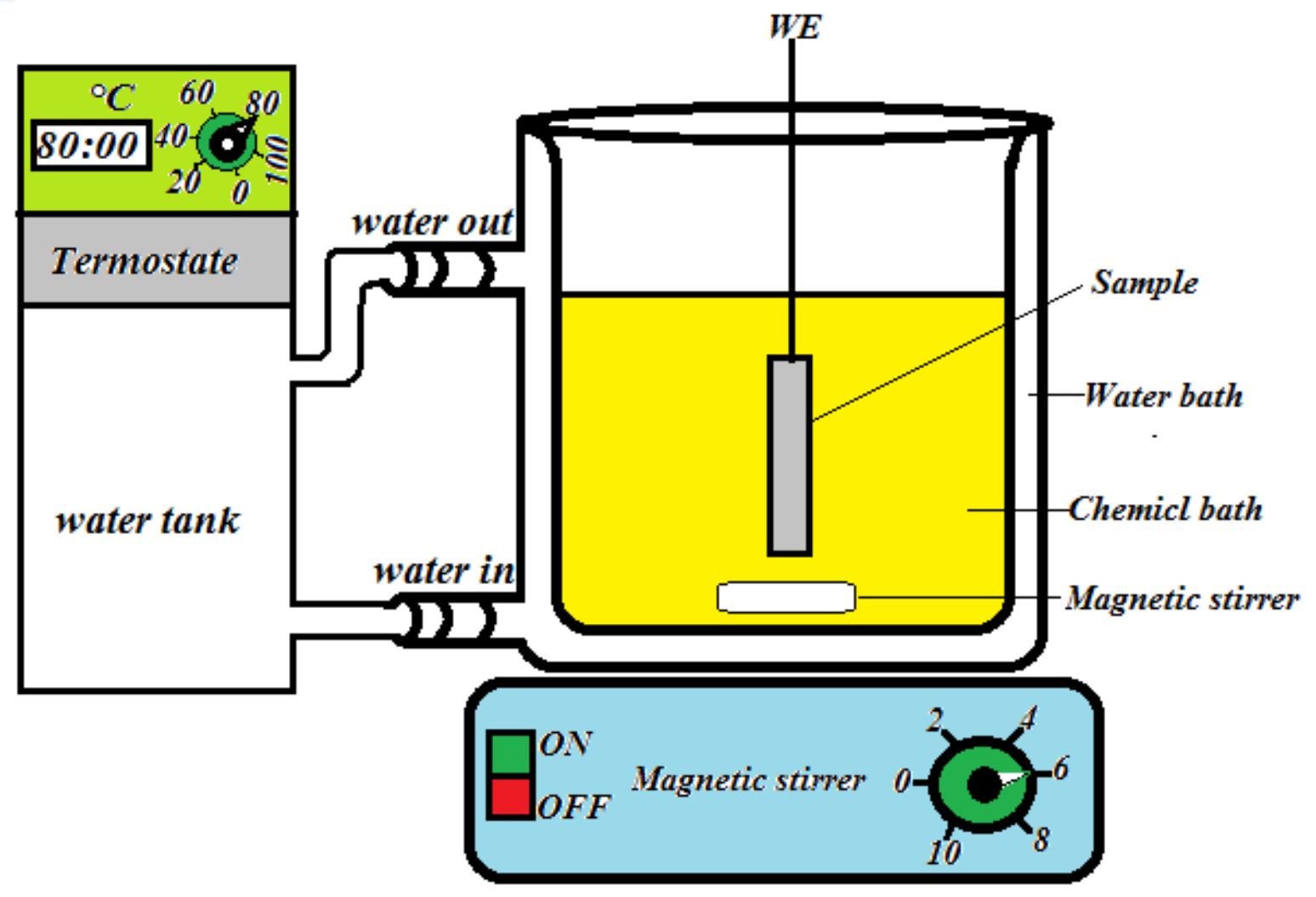

Figure 2.2 process of chemical bath deposition

\subsection{Annealing and Sulfurization process}

In order to investigate the effect of annealing on the physical and electro-optical properties of the thin films, selected as-grown films were heat treated in different ambient four main annealing regimes were adopted: annealing in vacuum, annealing in the presence of an inert gas such as argon (Ar) and annealing in a selenium atmosphere. The influence of various temperatures in the range 200 to $500^{\circ} \mathrm{C}$ was investigated. Two stage annealing was then employed to optimize the compositional, structural and electro-optical properties. Post deposition annealing in vacuum and selenium atmospheres was carried out in closed ended quartz tube evacuated by means of rotary pump. The shape of the ampoule allowed the sample and selenium to be physically separate (see figure 2.3). However, at elevated temperatures the selenium vapour was able to pass through the narrow neck of the ampoule from the selenium source to the sample by a diffusion process. 


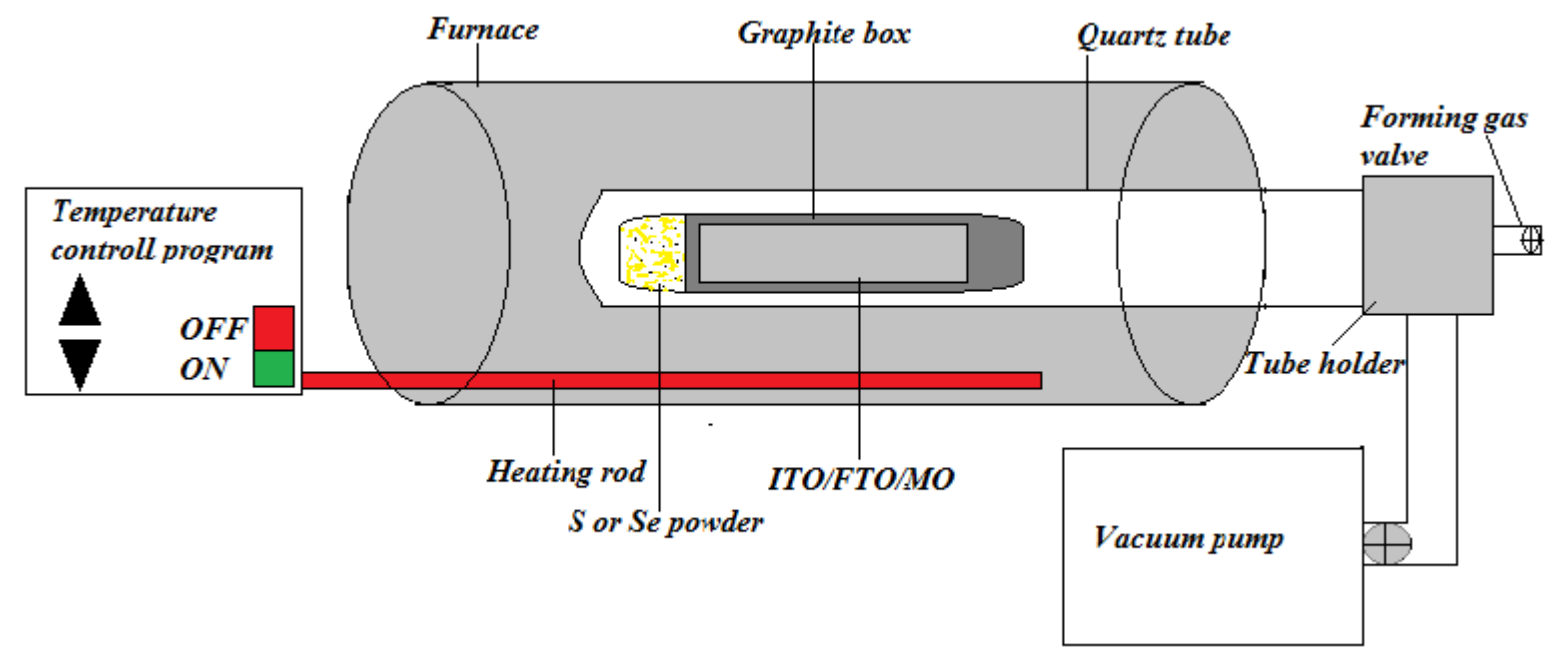

Figure 2.3 schematic diagram of annealing and sulfurization process.

\subsection{UV- Visible Spectroscopy}

The technique of optical spectroscopy has been used to measure the kinetic growth of nanoparticles and to characterize both inorganic and organic nanomaterials. It provides information on the absorption and emission spectra, which determine the electronic structures of ions, atoms, molecules, or crystal during the excitation of electrons from ground to excited states (absorption) and from excited to ground states (emission). The ultraviolet visible (UVvis) technique measures the absorption of photons in the visible, ultraviolet and near infrared ranges. The characteristic curves observed in the absorption and emission spectra indicate ions and atoms isolated by transitions between the energy levels. As a result, their wavelengths or photon energies can be determined.

In this work, UV-vis spectra were recorded using a high resolution (HR 4000-vis-NIR) spectrophotometer. A lamp produces a beam of light which hits a sample and splits into its component wavelengths. The specific wavelength of light reaches the exit aperture, before interacting with the sample. A detector then measures the transmittance and absorbance of the sample. Transmittance light passes through the sample and hits the detector, while absorbance is a measure of the light absorbed by the sample. The detector senses the light being transmitted through the sample and converts the information to a digital display. 


\subsection{X-ray Diffraction analysis}

X-ray diffraction is the most important and widely used method for characterizing of crystalline materials. It is a crystallographic tool used to identify the different crystalline phases present in solid materials and powder samples. As X-rays pass through atomic planes in crystals, can either be transmitted, or it will be scattered by the electrons of the atoms in the material. When two parallel X-rays scatter from two adjacent planes of atoms within the crystal, they can either do so constructively or destructively depending on their phase. Constructive interference occurs when two X-ray waves with phases separated by an integer number of wavelengths add to make a new wave with a larger amplitude, Figure 2.4.

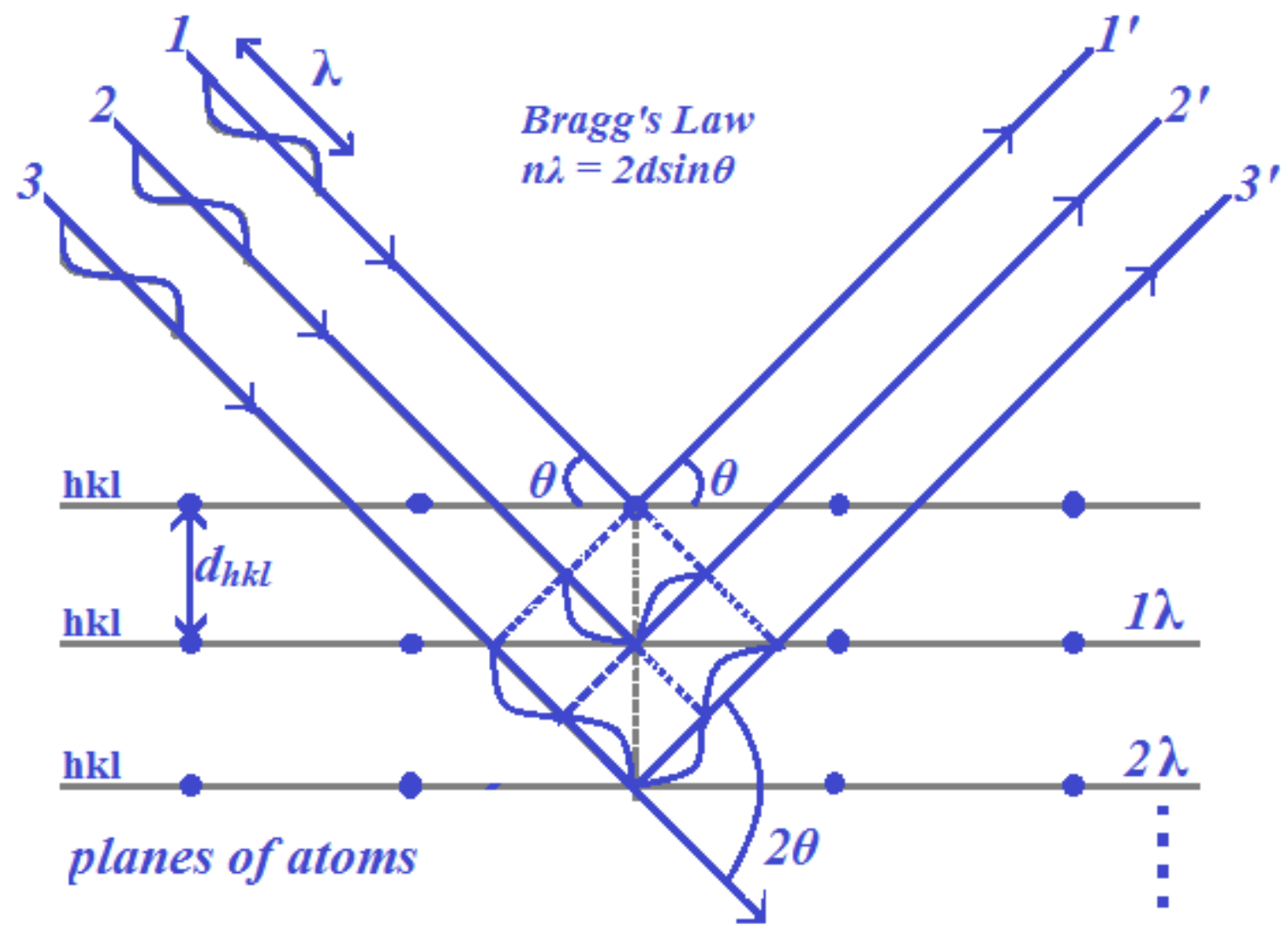

Figure 2.4 Schematic representation of diffraction of X-rays by a crystal (Bragg's Law)

The general relationship between the wavelength of the incident X-rays, angle of incidence and spacing between the crystal lattice planes of atoms is known as Bragg's Law and is expressed as: 


$$
\mathrm{n} \lambda=2 \mathrm{~d} \sin \theta
$$

Where $\mathrm{n}$ order of reflection, $\lambda$ is the wavelength of the incident X-rays, $d$ is the inter planar spacing of the crystal and $\theta$ is the angle of incidence. Since in a crystal atoms are arranged in a periodic fashion, the diffracted waves will consist of sharp interference maxima (peaks) with the same symmetry as in the distribution of atoms. Measuring the diffraction pattern therefore allows the determination of the distribution of atoms in a crystal.

X-ray diffraction can not only be used to identify the crystal phase of a material by comparison with data from known structures, but also to quantify changes in the cell parameters, crystal orientation, crystallite size and other structural parameters. The average crystallite size can be estimated from the X-ray diffraction pattern by using the Scherrer equation $[52,53]$

$$
\mathrm{D}=\mathrm{K} \lambda / \mathrm{B} \cos \theta
$$

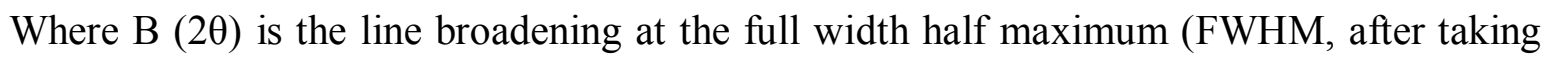
into account the instrument broadening), $\mathrm{K}$ is the Scherrer constant which is around $0.9, \lambda$ is the incident X-ray wavelength and D is the crystallite size.

\subsection{Field emission Scanning Electron Microscopy (FESEM)}

FESEM is a technique which is used to obtain topographical and morphological information about a sample (see figure 2.5). In SEM measurement, the sample under investigation is bombarded with a beam of electrons. The electron of an incident beam either excites an electron that leaves the sample if it has sufficient energy (called the secondary electron), or is scattered (called the back-scattered electron). Both secondary and backscattered electrons are detected by their respective detectors and then used to modulate the brightness of a cathode ray tube (CRT) after amplification. Secondary electrons generally originate near the surface of the sample. 


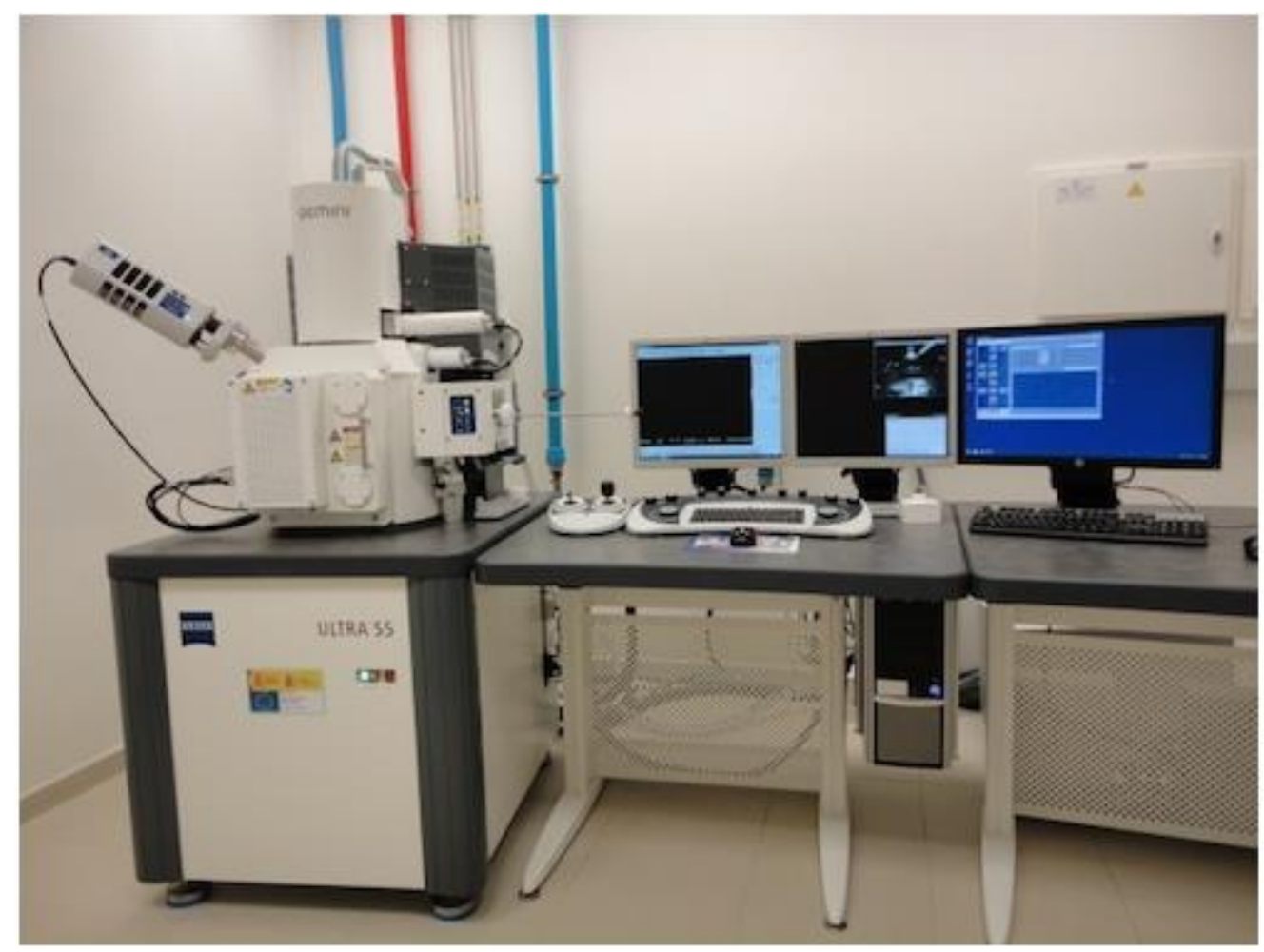

Figure 2.5 image of scanning electron microscopy (FESEM), a Zeiss ULTRA 55

If they originate deep inside the sample, they will lose sufficient energy in transit to the surface that they cannot leave the sample. The number of detected electrons changes depending on the orientation of the surface. Due to the change in the number of detected electrons, the brightness on the CRT monitor changes which results in a 3-dimensional image. On the other hand, back scattered electrons possess different energies depending on whether they were scattered from a heavier or a lighter nucleus. Electrons scattered from a heavier nucleus have a higher energy than the ones scattered from a lighter nucleus, and thus, the image of the heavier nucleus element appears brighter [54]. In our study, SEM was performed on thin films deposited on molybdenum and ITO substrate, using Zeiss ULTRA 55 Excel equipped with a $30 \mathrm{kV}$ field emission gun.

\subsection{Energy-dispersive Spectroscopy (EDS)}

Energy-dispersive Spectroscopy (EDS) allows for a quantitative compositional measurement of a specimen. EDS most commonly uses electrons as probes and measures x- 
rays emitted from atomic orbitals with specific energies that are characteristic to specific elements. Specifically, when an incident electron collides with inner core atomic electron, the core electron is ejected, leaving a hole. An outer shell electron fills the core electron and an $\mathrm{x}$-ray photon is emitted.

Typical operating voltages depend on two things: 1) the depth of the site of interest, the inclusion of peaks. Greater operating voltages tend to probe deeper in the specimen. This depth can be estimated using computer simulation software employing Monte Carlo simulations. Greater operating voltages also allow for the inclusion of higher energy peaks, increasing the accuracy of the characterization. Typical operating voltages are twice that of the peak of interest. Characterization accuracy is also increased by longer acquisition times, higher resolution detectors, and lower time spent on processing an x-ray event (dead time).

\subsection{Atomic Force Microscopy (AFM)}

An atomic force microscope is capable of providing a three dimensional image of the surface and is therefore very useful in measuring the surface roughness (see figure 2.6). In an AFM, a cantilever with a sharp tip (few hundred nanometers in diameter) made up of either $\mathrm{Si}$ or $\mathrm{SiO}_{2}$ is used. A laser is reflected on the back surface of the cantilever as a scan is in progress. If the laser changes positions due to force on the cantilever, a voltage is applied to the piezoelectric to make the laser go back to its origin. Since the force on the cantilever is caused by surface features on the specimen. The tip is kept in continuous or alternating contact with the sample surface and the cantilever is moved over the sample by using a piezo controller. Due to the topographical variation, the cantilever deflects and the deflection is measured using a laser beam reflected from the cantilever. The height of the tip changes during the movement of the cantilever and the magnitude of the deflection is plotted against the position of the tip on the surface which creates a topographic map of the surface [55]. 


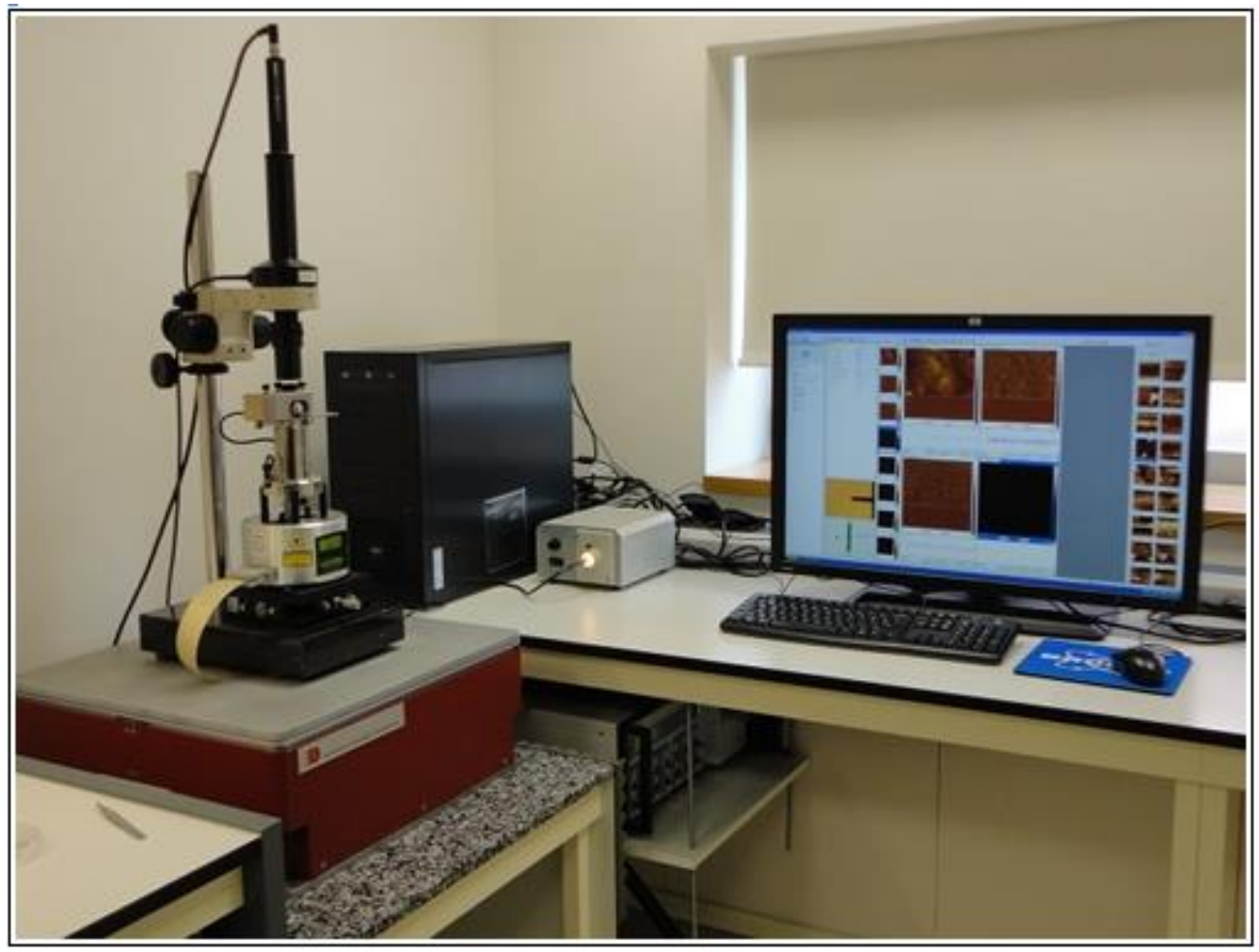

Figure 2.6 image of Bruker Multimode 8 atomic force microscopy (AFM)

\subsection{Transmission electron microscopy (TEM) analysis}

TEM is a microscopy technique in which a beam of electrons is transmitted in vacuum through a thin sample, interacting with it to reveal information including its particle size distribution. It is also capable of focusing on a single nanoparticle to identify directly its chemical and electronic structure. The principle behind TEM is similar to a slide projector: as the beam of electrons passes through the sample, only some parts of it are transmitted, forming a contrast image, which passes through a magnifying lens and is then projected onto a fluorescent screen or is detected by a charged couple device (CCD) camera. Figure 2.7 shows a photograph and a schematic diagram of a TEM set-up. The electron gun cathode, which is often made from tungsten filament, is heated by a high current to produce a stream of electrons. These are accelerated by a field of 100-300 keV and as they travel down the column, the increasing voltage increases their kinetic energy and decreases the effective wavelength. The condenser lenses are responsible for primary beam formation and focusing the beam to a small cylinder, while the condenser aperture eliminates any electrons scattered 
at wide angles. The beam hits the specimen on the sample holder and a large part of it is transmitted, magnified and focused by the objective lens and later the projector lenses. Finally, a fluorescent screen or CCD is used to form an image.

TEM is capable of creating diffraction patterns from a tiny area, which is called Selected Area Diffraction (SAD); by controlling the condenser lens settings, entering a selected area aperture and parallel incident beam illumination, a SAD from an area ranging hundreds to small nanometers in diameter is obtained.

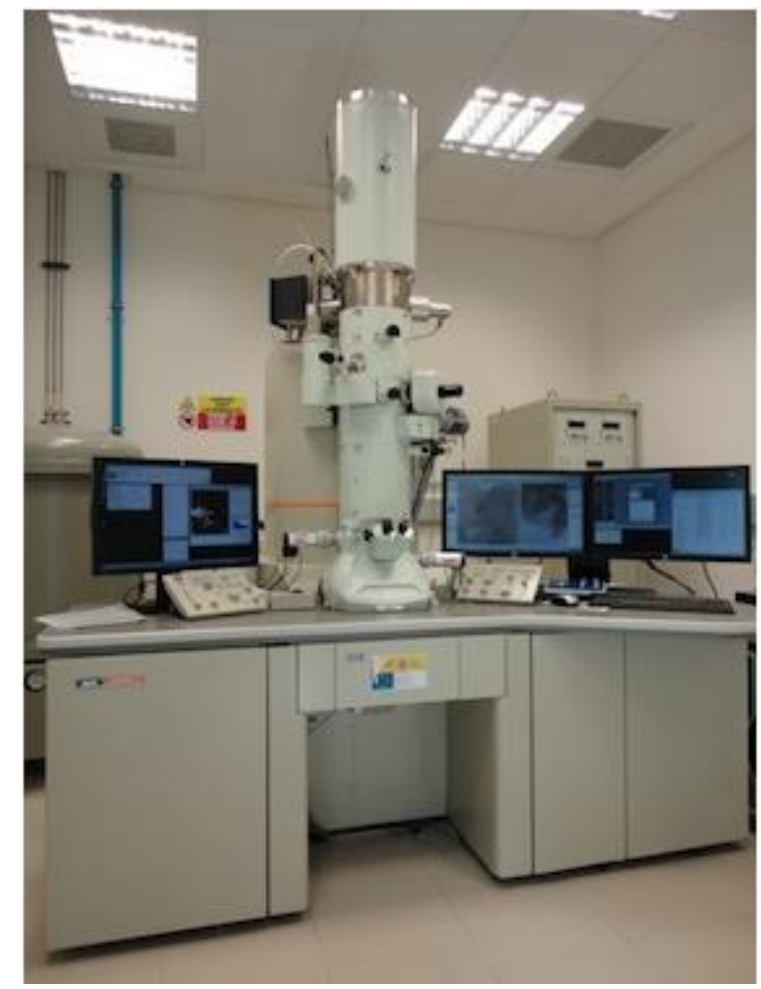

Figure 2.7 image of transmittance electron microscopy (TEM) JEOL JEM 2100F

Energy Dispersive X-ray Microanalysis (EDX) is used to measure the X-rays emitted during electron bombardment in a TEM to define the chemical composition of materials on nano and micro-scales. The elements present in the sample are determined from the X-ray energies emitted from the area being excited by the electron beam. The proportion of detection of characteristic X-rays gives a measure of the amounts of different elements present in the sample. Weight percentages are calculated using specific peak energies relating to individual 
energy shells of each atom of each element and peak areas are determined using an internal calibrated standard, usually cobalt.

The work reported in this thesis, TEM measurements of thin films were achieved using a JEOL JEM 2100F operating at $200 \mathrm{keV}$. Samples were prepared by drop casting dispersions of the film in ethanol on holey carbon copper grids.

\subsection{Photo electrochemical analysis}

The main component of the PEC cell is the semiconductor, which converts incident photons to electron-hole pairs. These electrons and holes are spatially separated from each other due to the presence of an electric field inside the semiconductor, Figure 2.8 shows a simplified energy diagram which n-type semiconductor electrodes will constitute the anode and a counter electrode, consequently called the cathode. The two electrodes are interconnected via an external circuit source. An electrolyte is applied to the solar cell, acting as a conducting mediator between the electrodes. A light source Xenon lamp is using for illumination of semiconductor films, various long-wave band pass filters is located between the light source and the sample electrode [56]. The working electrode can be composed of a semiconductor material, polycrystalline or nanocrystal line, which is attached to a conducting substrate.

When n-doped semiconductors are brought into contact with an electrolyte, current will flow until their electrochemical potentials are equalized and equilibrium is attained. The absorption of photons with an energy exceeding the band gap generates electron-hole pairs close to the semiconductor electrolyte interface. In case the Fermi level (EF) lies above the standard redox potential ( $V_{\text {o redox }}$ ), electrons will be withdrawn from the semiconductor to the electrolyte, leaving positive charges behind. A charge separation will occur when the holes reach the surface and react with the electrolyte. The electric field is important regarding the separation process of the photo generated electron/hole pairs. The charge ordering in the electrolyte is often described in the terms of Helmholtz and Gouy-Chapman layers [57]. 


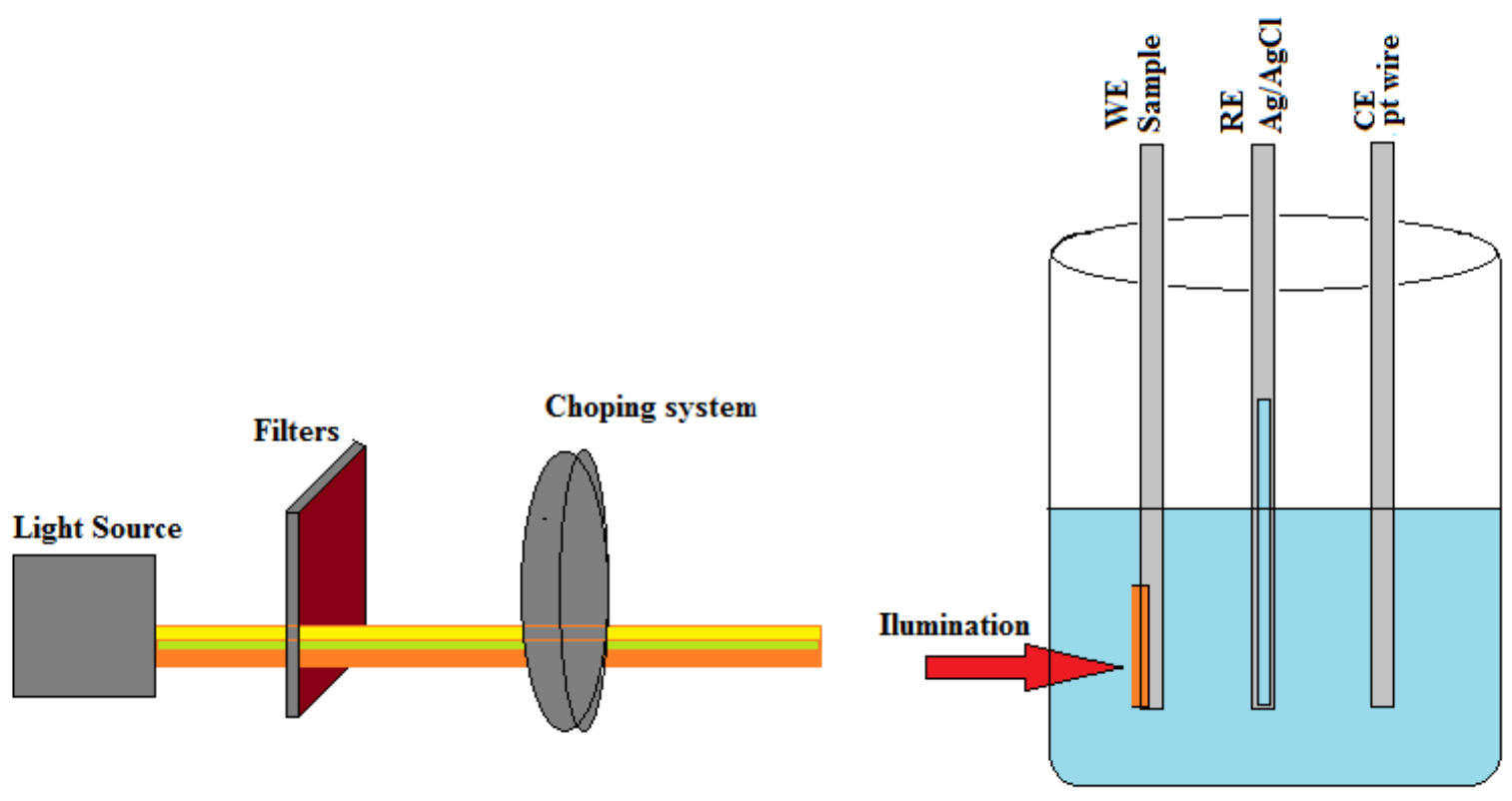

Figure 2.8 A schematic diagram of photo electrochemical (PEC) cell.

\subsection{Current-Voltage (J-V) Measurements}

The efficiency of a solar cell is assessed through its current-voltage (J-V) characteristic that provides quantitative information on the overall device quality and helps in identifying problems within the solar cell and those associated with its electrical contacts. A solar cell, when not under illumination (i.e. in the dark), the current in a diode can further be described by the Schokley diode equation [58], which is given by

$$
I_{d}=I_{0}\left(\exp \left(\frac{q V d}{n k T}\right)-1\right)
$$

where $I_{d}$ is the net current flowing through the cell, $I_{0}$ is the dark saturation current (or leakage current), $V_{d}$ is the applied voltage, $q$ is the electron charge, $n$ is the diode ideality factor, $\mathrm{k}$ is Boltzmann's constant, and $\mathrm{T}$ is the absolute temperature in Kelvins. On the other hand, when light is incident on the solar cell, the total current is a superposition of both the dark current and the light generated current $\left(I_{L}\right)$ [59].

$$
I=I_{d}-I_{L}=I_{0}\left(\exp \left(\frac{q V}{n k T}\right)-1\right)-I_{L}
$$


The two currents travel in opposite directions in the solar cell. The photo generated electrons and holes move through the external circuit with the ability to do work in the process. When the applied forward voltage during a $\mathrm{J}-\mathrm{V}$ measurement is large enough, it forward biases the diode, and then, the electrons and holes overcome the potential barrier which gives rise to the diode current, Id. In applications of the solar cell, however, the voltage drop on the load resistance due to the light generated current forward biases the junction. Equations 2.1 and 2.2 can be used to generate J-V curves as shown in Figure 2.9, the quality of a solar cell is measured in terms of four different performance parameters. The first parameter is the short circuit current, $\mathrm{J}_{\mathrm{SC}}$, which is equivalent to IL in Equation 2.2. This is the current when the solar cell is short circuited. The short circuit current results from the generation of charge carriers by light and the separation of those charge carriers by the built-in electric field. $J_{\mathrm{SC}}$ depend on factors such as the spectrum and the irradiance of the light used, the area of the solar cell, the optical properties of the materials in the solar cell and their thicknesses, and the lifetime of minority carriers in the absorber layer and the window layer.

The second parameter is the voltage developed across the terminal of a solar cell when it under open circuit conditions, so that no current can flow. This voltage is known as the open circuit voltage, $V_{O C}$. The open circuit voltage depends on several factors such as the bandgap of the active layer, behavior of the diode in the dark, defect density at the junction, and recombination losses.

The third performance parameter provided by the J-V measurement is known as the fill factor, $F F$, which is a ratio of the maximum power output of the solar cell to the product of $J_{S C}$ and $V_{O C}$, given by

$$
F F=\frac{P_{\max }}{V_{O C} \times I_{S C}}=\frac{V_{\max } \times I_{\max }}{V_{O C} \times I_{S C}}
$$

Where $\mathrm{J}_{\mathrm{MP}}$ and $\mathrm{V}_{\mathrm{MP}}$ are the current density and voltage values, respectively, at the maximum power point, as shown in Figure 2-6. The fill factor also depends on defect density in the bulk of the semiconductor and the junction, as well as on the parasitic resistances, known as shunt and series resistances, present in the solar cell. The fourth parameter is the efficiency of the solar cell, which is the ratio of the power output of the solar cell to the incident power. The efficiency of a solar cell is given by: 


$$
\eta=\frac{P_{\max }}{P_{\text {in }}}=\frac{I_{\max } \times V_{\max }}{\text { Incident solar radiation } \times \text { Area of solar cell }}
$$

Where FF is given in Equation 2.4 and $\mathrm{P}_{\text {in }}$ is the input power from the sun or a solar simulator. It should be noted that all four of these parameters can be dependent on the spectrum used for measurement, as well as on the measurement temperature. Solar cells are typically measured at room temperature and with an AM 1.5 solar spectrum [60].

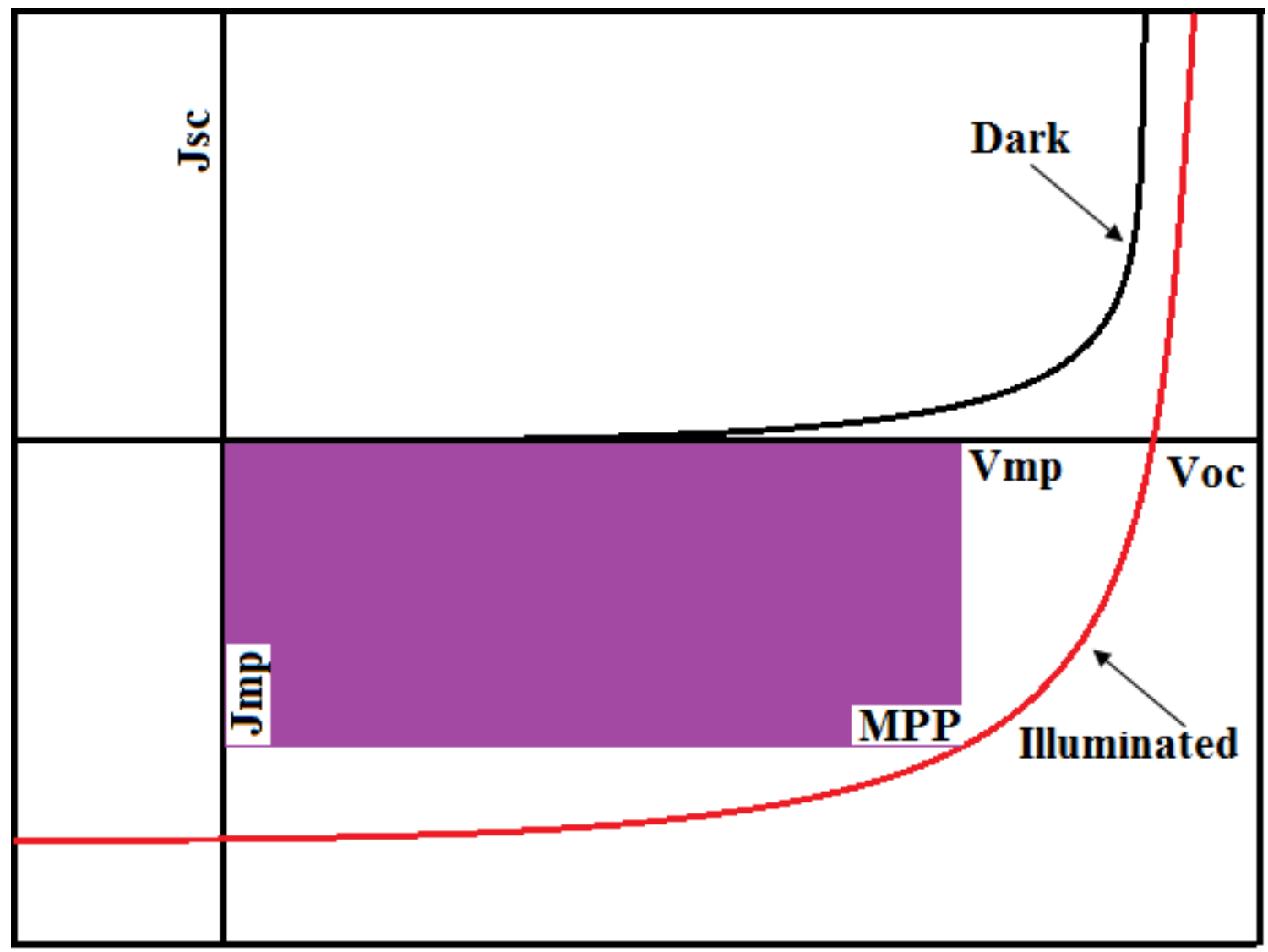

Figure 2.9. Example of $\mathrm{J}-\mathrm{V}$ curves for a solar cell in the dark and for the same solar cell under illumination.

\subsection{External quantum efficiency measurement}

Another important efficiency for solar cells is the external quantum efficiency (EQE). The EQE measurement is an extremely useful tool for the identification of different loss 
mechanisms in solar cells, e.g., the surface recombination, the bulk recombination due to low diffusion length and the back contact recombination. It is defined as the ratio of the number of charge carriers collected by the solar cell to the number of incident photons of a given wavelength, or that of the photo current (charge carriers per second) to the photon flux (photons per second). In this work EQE measurements were used to determine the optical band gap energy $\mathrm{E}_{\mathrm{g}}$ of the CIGS absorbers. Physically, EQE at a given photo energy hv can be expressed as [61]

$$
\mathrm{EQE}(\mathrm{h} v)=1-\frac{\exp (-\alpha W)}{\alpha L_{e f f}+1}
$$

With the absorption coefficient $\alpha$ at the photo energy h $v$, the depletion width $\mathrm{W}$ of the solar cell and the effective diffusion length $\mathrm{L}_{\mathrm{eff}}$ for minority charge carriers. For photo energies near the band gap energy, the term $\alpha \mathrm{L}_{\text {eff }}$ is smaller than 1 (based on $\alpha<10^{-4} \mathrm{~cm}^{-1}$ for CuInSe 2 and $\left.\mathrm{L}_{\text {eff }} \approx 1 \mu \mathrm{m}[62,63]\right)$. Consequently, Eq. 2.3 can be reduced to

$$
\mathrm{EQE}(h v)=1-\exp (-\alpha \mathrm{W})
$$

And thus

$$
\alpha=\frac{1}{W} \ln (1-\mathrm{EQE}(\mathrm{h} v))
$$

For a direct transition, the dependence of the absorption coefficient on the photo energy is given by [64]

$$
\alpha \mathrm{h} v \propto(\mathrm{h} v-\mathrm{Eg})^{1 / 2}
$$

By substituting a in Eq. 2.6 with Eq. 2.5 and taking the square function of both sides, the following relation is available

$$
[\mathrm{h} v * \ln (1-\mathrm{EQE}(\mathrm{h} v))]^{2} \propto \mathrm{h} v-\mathrm{Eg}
$$

Therefore, the band gap energy Eg can be extrapolated with the expression [ h $v * \ln (1-\mathrm{EQE}$ $(h v))]^{2}$, which is a function of the photo energy hv. 
This page intentionally left blank 


\section{Chapter 3}

\section{Synthesis and characterization of $\mathrm{Cu}(\mathrm{In}, \mathrm{Ga})(\mathrm{Se}, \mathrm{S})_{2}$ thin films}

\subsection{Introduction}

Among the leading thin film solar technologies, thin film solar cells are one of the most promising technology for the production of clean and low cost energy. This is due to a greatly reduced consumption of semiconductor material and to the fact that solar cell can be manufactured on in expensive large-area substrates. In this way, PV modules with a final cost well below US $\$ 0.50$ per peak watt (Wp) can be produced [65].

The $\mathrm{Cu}(\mathrm{In}, \mathrm{Ga})(\mathrm{S}, \mathrm{Se})_{2}$ ternary and quaternary semiconductor compounds are the most widely used absorption materials for photovoltaics applications is now well established, due to their unique structural and photoelectric properties [66,67]. At present, research on this class of materials has focused on IIIA, VIA compounds, such as $\mathrm{CuInSe} 2, \mathrm{Cu}(\mathrm{In}, \mathrm{Ga}) \mathrm{Se}_{2}$, $\mathrm{Cu}(\mathrm{In}, \mathrm{Ga}) \mathrm{S}_{2}$ and so on $[68,69,70]$. Among these semiconductor compounds, The most prominent members of this family, $\mathrm{Cu}(\mathrm{In}, \mathrm{Ga}) \mathrm{Se}_{2}$ (CIGS), when used as absorbing layers in thin-film solar cells, regularly exhibit power conversion efficiencies of $\sim 22.3 \%$ to date [71] . One of the main reasons for such a large power conversion efficiency is the relatively large size of the grains (of the order of a few micrometers) into which they crystallize and the relatively benign nature of the scattering properties of the grain boundaries between them. $[72,73,74]$. The large size of the grains implies that their electronic structure is similar to that

of the bulk crystal. Moreover, the alignment of the bottom of the conduction band between the absorbing chalcopyrite layer and the surrounding buffer and transparent conducting layers favors quick drift of the electrons in thin-film solar cell devices [75,76]. These chalcopyrite materials also exhibit a very large absorption coefficient of $10^{5}\left(\mathrm{~cm}^{-1}\right)$ above the absorption edge as opposed to the majority of the III-V semiconductors with absorption coefficients of $10^{4}\left(\mathrm{~cm}^{-1}\right)$ and have yielded highest conversion efficiencies among thin film technologies at laboratory scale $[77,78,79]$. 


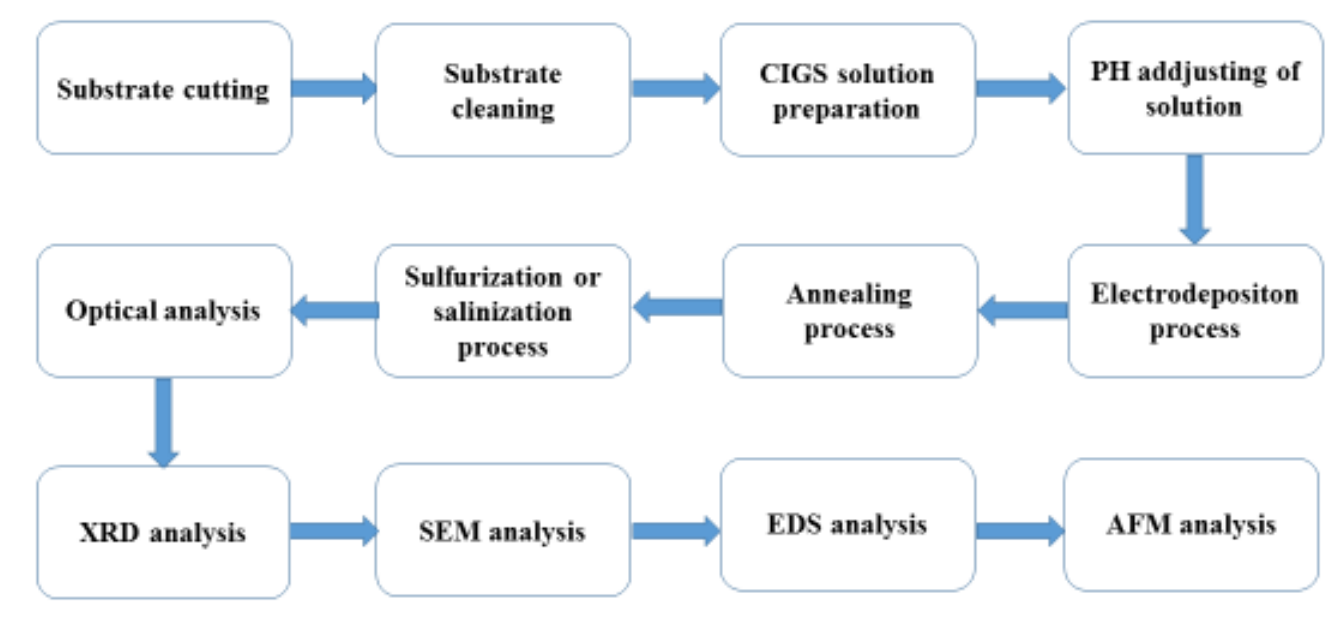

Figure 3.1 A flowchart of the process used for depositing all samples on different substrates.

The experimental apparatus described in Chapter 2 was used in this study.

\subsection{Substrate cleaning}

The substrates are first rinsed in sprays of deionized (DI) water to remove any major contaminations attached on the surface. They are then vertically placed in a Teflon substrate holder. The substrate holder is then put in a hot DI water bath at approximately $60{ }^{\circ} \mathrm{C}$ for 15 minutes with all glass substrates completely immersed in the bath. The substrates are then taken out and dipped in DI water dissolved with Alconox detergent. They are then individually taken out of the holder and physically scrubbed with a clean brush and then put back in the holder. Both the sides and edges are cleaned to remove all possible contaminations. The substrates are rinsed again in sprays of DI water and put in a second hot DI water bath in an ultrasonic cleaner. All substrates are completely immersed in the bath and the ultrasonic cleaning takes about 15 minutes. The holder are then removed from the ultrasonic cleaner and placed in a three stage cascade rinse agitated with nitrogen bubbles. Finally, the substrates are individually dried with nitrogen gun and placed in storage boxes. 


\subsection{Preparation of $\mathrm{Cu}(\mathrm{In}, \mathrm{Ga}) \mathrm{Se}_{2}$ thin films}

The growth mechanisms of various Chalcopyrite $\mathrm{Cu}(\mathrm{In}, \mathrm{Ga}) \mathrm{Se}_{2}$ (CIGS) synthesis methods have been analyzed in depth, with the goal of optimizing device fabrication and improving performance. The co-electrodeposition technique where $\mathrm{Cu}-\mathrm{In}-\mathrm{Ga}-\mathrm{Se}$ species are present in the same bath is one of the suitable techniques to prepare low cost thin films [80] because the deposition process is carried out at low temperatures, ambient pressure and does not require very sophisticated and expensive equipment.

Electrodeposition was carried out potentiostatically in a three-electrode cell configuration where the reference electrode was $\mathrm{Ag} / \mathrm{AgCl}$, the counter electrode a platinum wire, and the working electrode were 1- $\mu \mathrm{m}$-thick Mo-coated glass and ITO-coated substrates. All substrates were ultrasonically cleaned with acetone, rinsed with deionized water and subsequently dried. The films were obtained in a vertical cell in which the working and the counter electrode were suspended vertically from the top of the cell.

Before deposition, the solution was deaerated by argon bubbling and stirred up for 20 minutes. The applied potential was fixed at $-0.6 \mathrm{~V}$ versus the reference electrode $(\mathrm{Ag} / \mathrm{AgCl})$ and the electrodeposition period was $30 \mathrm{~min}$. The temperature was maintained at $25{ }^{\circ} \mathrm{C}$ without stirring the solution during the deposition. All electrodeposition procedures were performed using Auto lab PGSTAT 302N.

$\mathrm{CuGaSe}_{2}$ layers were electrodeposited from an electrolyte solution containing of $2 \mathrm{mmol} \mathrm{L}^{-1}$ $\mathrm{CuCl}_{2}, 4 \mathrm{mmol} \mathrm{L}^{-1} \mathrm{H}_{2} \mathrm{SeO}_{3}, 10 \mathrm{mmol} \mathrm{L}^{-1} \mathrm{GaCl}_{3}, 50 \mathrm{mmol} \mathrm{L}^{-1} \mathrm{KSCN}, 100 \mathrm{mmol} \mathrm{L}^{-1} \mathrm{NH}_{4} \mathrm{Cl}$ and $300 \mathrm{mmol} \mathrm{L}^{-1} \mathrm{LiCl}$. The $\mathrm{pH}$ was adjusted to 2.3 by adding potassium hydroxide $(\mathrm{KOH})$ and hydrochloric acid $(\mathrm{HCl})$. Addition of $\mathrm{LiCl}$ as supporting electrolyte provides better stability of the electrodeposition bath solution and also improves the quality of the deposited layers. After electrodeposition, the as-deposited films were annealed at $450{ }^{\circ} \mathrm{C}$ under forming gas $\left(10 \% \mathrm{H}_{2}\right.$ in $\left.\mathrm{N}_{2}\right)$ atmosphere with a pressure of $10^{-2}$ bar to improve the crystallinity of the $\mathrm{CuGaSe}_{2}$ films.

\subsubsection{Cyclic voltammetry}

The cyclic voltammetry carried out in a three-electrode electrochemical cell at a scan rate of $100 \mathrm{mV} \mathrm{s}^{-1}$ which is describe in Figure 3.2. The dashed black curve represents the 
cyclic voltammetry for the blank solution. Showing a peak at $-0.81 \mathrm{~V}$ attributed to the reduction of $\mathrm{H}^{+}$to $\mathrm{H}_{2}$. The red curve is the cyclic voltammetry for a copper-selenium solution. It shows a reduction peak at $-0.69 \mathrm{~V}$ attributed to the formation of copper selenides. The blue curve is the cyclic voltammetry of the former solution after addition of $\mathrm{Ga}^{3+}$. The addition of $\mathrm{Ga}^{3+}$ shifts the former peak from $-0.69 \mathrm{~V}$ until $-0.57 \mathrm{~V}(+0.12 \mathrm{~V})$ and it is attributed to $\mathrm{Ga}_{2} \mathrm{Se}_{3}$ (eq. 1). Then, the generated $\mathrm{Ga}_{2} \mathrm{Se}_{3}$ is assimilated into copper selenides and, according to ref. [81], is rapidly transformed into copper gallium diselenide (eq. 2).

$$
\begin{gathered}
3 \mathrm{H}_{2} \mathrm{Se}+2 \mathrm{Ga}^{3+} \leftarrow \rightarrow \mathrm{Ga}_{2} \mathrm{Se}_{3}+6 \mathrm{H}^{+} \\
\mathrm{Cu}_{2} \mathrm{Se}+\mathrm{Ga}_{2} \mathrm{Se}_{3} \leftarrow \rightarrow 2 \mathrm{CuGaSe}_{2}
\end{gathered}
$$

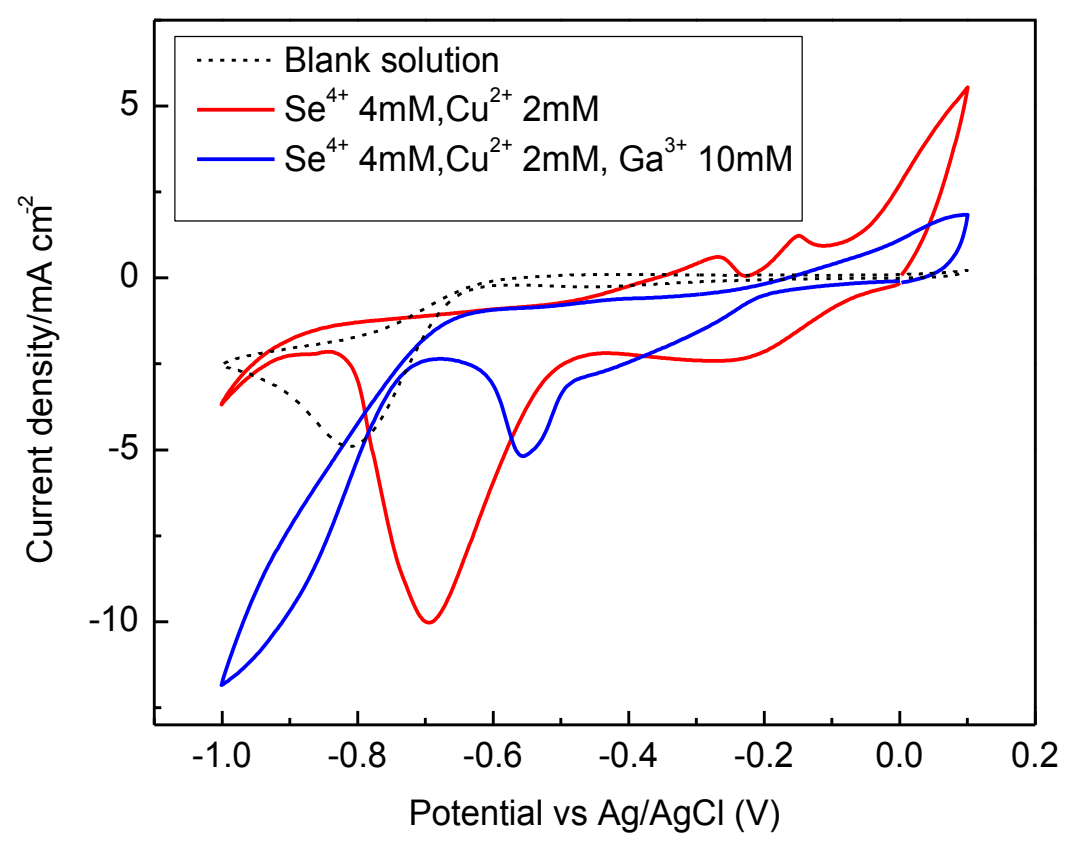

Figure 3.2 Cyclic Voltammograms of a Mo-coated electrode in three precursor electrolytes: blank solution (dashed line), $4 \times 10^{-3} \mathrm{~mol} \mathrm{~L}-1 \mathrm{Se}^{4+}, 2 \times 10^{-3} \mathrm{~mol} \mathrm{~L}^{-1} \mathrm{Cu}^{2+}$ (red line) and (blue line). $1 \times 10^{-2} \mathrm{~mol} \mathrm{~L}^{-1} \mathrm{Ga}^{3+}$. Each solution contains $0.3 \mathrm{~mol} \mathrm{~L}^{-1} \mathrm{LiCl}_{2}$ as supporting electrolyte and the $\mathrm{pH}$ was adjusted to 2.3 . The sweep rate was $100 \mathrm{mV} \mathrm{s}^{-1}$. 


\subsubsection{Electrodeposition}

Electrodeposition is a process of depositing films onto an electrode, with the chemical changes in a solution. Metals in solutions may be either in cationic or anionic forms, and ions move with individual mobility's toward the electrodes under the influence of an electric charge. Since the mobility's of various ions are different, it follows that, in a given solution, more current may be carried by cations than by anions or vice versa. Different factors like

$\mathrm{pH}$, current density, bath composition etc. can influence the properties of electrodeposited material. Bhattacharya [82] first made electrodeposited CIS thin film in 1984. This technique, although, at early stages in its development for CIS, has considerable potential for coating large area substrates.

\subsection{Post deposition heat treatments}

In order to investigate the effect of annealing on the physical and electro-optical properties of the thin films, figure 3.3 schematic illustration show the post deposition process, there are two line red and black, the red one show the maximum temperature and the black one is show the required temperature, $\mathrm{t} 2$ represent the time in which we need to reached up to the required temperature which is $450{ }^{\circ} \mathrm{C}$, then $\mathrm{t} 3$ is the time where temperature keep constant for 40 minutes and $t 4$ is the down fall temperature time. The as-grown films were heat treated in different ambient. Four main annealing regimes were adopted: annealing in vacuum, annealing in an ambient of 9: 1 mixture of $\mathrm{N} 2$ : $\mathrm{H} 2$, annealing in the presence of an inert gas such as argon and annealing. The as-deposited films were annealed at $450{ }^{\circ} \mathrm{C}$ under forming gas $\left(10 \% \mathrm{H}_{2}\right.$ in $\left.\mathrm{N}_{2}\right)$ atmosphere with a pressure of $10^{-2}$ bar to improve the crystallinity of the $\mathrm{CuGaSe}_{2}$ films. Two stage annealing was then employed to optimize the compositional, structural and electro-optical properties. Post deposition annealing in vacuum and selenium atmospheres was carried out in closed ended Pyrex tubes evacuated by means of rotary pump. However, at elevated temperatures the selenium vapour was able to pass through the narrow neck of the ampoule from the selenium source to the sample by a diffusion process. After removing from the furnace the film appeared uniformly gray with some dark patches on one side. 


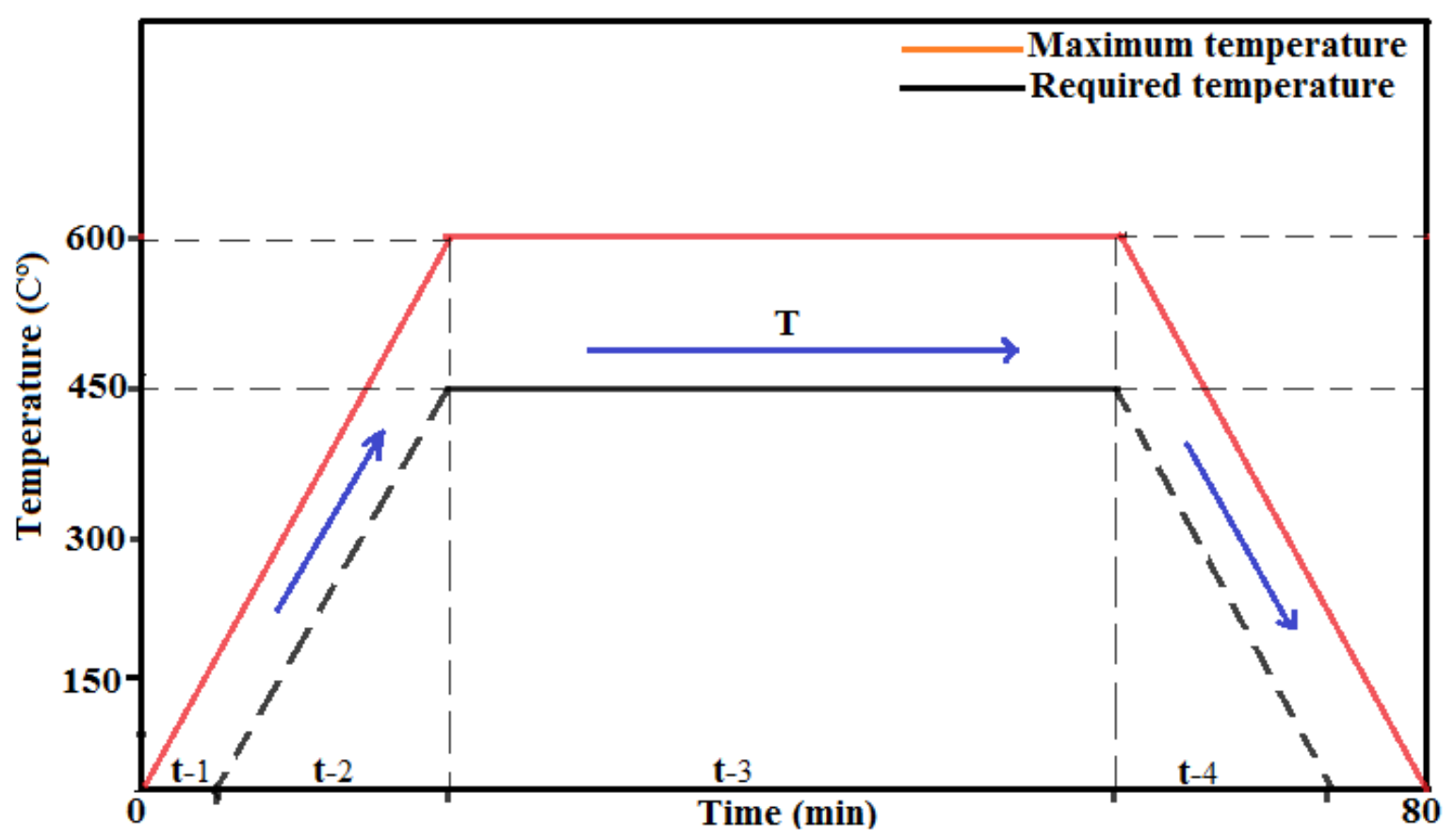

Figure 3.3: Schematic illustration of a typical temperature profile for the post annealing treatment.

\subsection{Engineering of Bandgap by Ga addition and sulfurization}

Incorporation of $\mathrm{Ga}$ and $\mathrm{S}$ leads to an increase in the bandgap of CIS [83] by increasing the energy of the conduction band in the case of Ga [84] while main effect of sulfur is to reduce the valance band maximum energy [85]. The increase in bandgap with gallium content, $\mathrm{x}$ is governed by the relation $\mathrm{Eg}(\mathrm{eV})=1.010+0.626 \mathrm{x}-0.167 \mathrm{x}(1-\mathrm{x})$ [86].

Whereas the increase in the bandgap with gallium content, $\mathrm{x}$ and sulfur content, $\mathrm{y}$ is governed by the relation,

$$
\mathrm{Eg}(\mathrm{eV})=1+0.13 \mathrm{x}^{2}+0.08 \mathrm{x}^{2} \mathrm{y}+0.13 \mathrm{x} y+0.55 \mathrm{x}+0.54 \mathrm{y}
$$

Gallium tends to diffuse towards the back contact and form $\mathrm{CuIn}{ }_{1-\mathrm{x}} \mathrm{Ga}_{\mathrm{x}} \mathrm{Se}_{2}$ having higher gallium content [88]. As gallium content increases in $\mathrm{CuIn}_{1-\mathrm{x}} \mathrm{Ga}_{\mathrm{x}} \mathrm{Se}_{2}$, bandgap also increases as CGS is a wide bandgap semiconductor with a bandgap of $1.66 \mathrm{eV}$. The bandgap gradient created between gallium poor CuIn ${ }_{1-x} \mathrm{Ga}_{x} \mathrm{Se}_{2}$ and gallium rich $\mathrm{CuIn}_{1-\mathrm{x}} \mathrm{Ga}_{\mathrm{x}} \mathrm{Se}_{2}$ creates a back surface field (BSF) that acts as a mirror for the electrons moving towards the back contact. The BSF greatly suppresses the back contact recombination and increases the open circuit 
voltage [89]. Also the formation energy for a $\mathrm{GaCu}$ defect is higher than the formation energy of InCu. This destabilizes the formation of defect pairs of $2 \mathrm{~V}_{\mathrm{Cu}}+\mathrm{In}_{\mathrm{Cu}}$ thereby reducing the tendency for the formation of ODC [90] and enhancing the $\alpha$-CIGS region.

Sulfurization of metallic precursors is a well-developed process to produce a high bandgap $(2.2 \mathrm{eV})$ absorber. Sulfurization is considered as a bandgap engineering treatment for the selenide absorber. The open-circuit voltage, $\mathrm{V}_{\text {oc }}$ mainly depends on the band gap in the space charge region. CIGS with $\mathrm{Ga} \sim 30 \mathrm{at} \%$ has a bandgap of $1.66 \mathrm{eV}$, this comparatively lower bandgap value, results in relatively lower open circuit voltage $\left(\mathrm{V}_{\mathrm{oc}}\right)$. Sulfurization leads to the formation of CIGSeS or $\mathrm{CIGS}_{2}$ layer at the interface. Having a wider bandgap of $2.2 \mathrm{eV}$ at the $p-n$ junctions helps in increasing the open circuit voltage $\left(\mathrm{V}_{\mathrm{oc}}\right)$. During the sulfurization treatment the sulfur atoms occupy already existing selenium vacancies or replace selenium because of the higher reactivity of sulfur compared to selenium, thereby reducing the compensating donors and also passivating the surface [91].

\subsubsection{Sulfurization process of $\mathrm{CuGaSe}_{2}$ thin films}

The $\mathrm{CuGaS}_{2}$ layers were obtained by performing a subsequent sulfurization process to electrodeposited $\mathrm{CuGaSe}_{2}$ layers. The sulfurization process was carried out by annealing the as-deposited $\mathrm{CuGaSe}_{2}$ thin films in a graphite box. $100 \mathrm{mg}$ of molecular sulfur were added to the graphite box, which was placed in a quartz tube kept in forming gas atmosphere at a pressure of $10^{-2}$ bar. The quartz tube was located inside a cylindrical oven at a temperature of $400{ }^{\circ} \mathrm{C}$ for 10 minutes. After the sulfurization treatment the sample appeared uniform gray with no patches.

\subsubsection{Chromium doped with $\mathrm{CuGaS}_{2}$ thin films.}

For doping purposes $\mathrm{Cr}^{3+}$ ions were added to the electrolyte described above. 150 $\mathrm{mMol} \mathrm{L}{ }^{-1}$ of $\mathrm{Cr}\left(\mathrm{ClO}_{4}\right)_{3}$ were dissolved in $40 \mathrm{ml}$ of the electrolyte aqueous solution. In this case the $\mathrm{pH}$ of the final solution was adjusted between 2.3 and 2.4 by using concentrated $\mathrm{HCl}$. Electrodeposition produces $\mathrm{Cr}$-doped $\mathrm{CuGaSe}_{2}$ films and these films were subsequently sulfurized following the sulfurization procedure described before. 


\subsection{Characterization techniques for $\mathrm{Cu}(\mathrm{In}, \mathrm{Ga})(\mathrm{Se}, \mathrm{S})_{2}$ thin films}

\subsubsection{X-Ray diffraction analysis}

Figure 3.4 shows the XRD patterns of $\mathrm{CuGaSe}_{2}$ and $\mathrm{CuGaS}_{2}$ thin films at their different preparation stages: (a) as deposited $\mathrm{CuGaSe}_{2}$, (b) $\mathrm{CuGaSe}_{2}$ thin films annealed at $450{ }^{\circ} \mathrm{C}$ in forming gas atmosphere and (c) sulfurized $\mathrm{CuGaSe}_{2}$ thin films annealed for 10 minutes $450^{\circ} \mathrm{C}$. The XRD pattern of the as-deposited sample, Figure. 3.4 (a), does not show visible peaks except for the Mo substrate, meaning poor crystallinity of the as-deposited films. After thermal annealing, an improvement in the sharpness and intensity of the diffraction peaks is observed due to the crystallization and grain growth.

Figure 3.4 (b) displays the X-ray diffraction pattern of the annealed $\mathrm{CuGaSe}_{2}$ sample. This diffractogram matches well with the tetragonal crystal system JCPDS No. 075-0104 pattern, corresponding to $\mathrm{CuGaSe}_{2}$. The major peaks are located at $27.9^{\circ}, 46.2^{\circ}$ and $54.4^{\circ}$, respectively, corresponding to (lll 112$),\left(\begin{array}{lll}2 & 2 & 0\end{array}\right) /\left(\begin{array}{lll}2 & 0 & 4\end{array}\right)$ and $\left(\begin{array}{lll}3 & 1 & 2\end{array}\right) /\left(\begin{array}{lll}1 & 1 & 2\end{array}\right)$ diffraction planes.

The sulfurization process of the as-deposited $\mathrm{CuGaSe}_{2}$ films takes place after a short annealing time in presence of molecular sulfur, resulting in the formation of the $\mathrm{CuGaS}_{2}$ chalcopyrite phase as revealed by the XRD pattern of sulfurized films.

Figure 3.4 (c) presents the X-ray diffraction pattern of a sulfurized $\mathrm{CuGaSe}_{2}$ sample. The XRD peaks shift to higher angles with the sulfurization process. The main XRD peak corresponding to $\left(\begin{array}{lll}1 & 1 & 2\end{array}\right)$ diffraction peaks shifts from 27.9 to 29.0 degrees. Further, the peaks

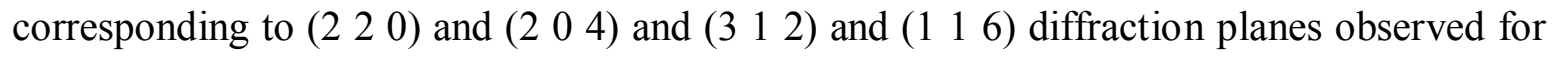
annealed $\mathrm{CuGaSe}_{2}$ films also shift to higher angles for sulfurized films. This XRD peaks match well with the JCPDS No. 75-0103 pattern corresponding to $\mathrm{CuGaS}_{2}$ films. This diffraction pattern confirms that, after sulfurization, Se atoms have been replaced by $\mathrm{S}$ atoms, and consequently $\mathrm{CuGaSe}_{2}$ thin films have been transformed into $\mathrm{CuGaS}_{2}[92,93,94]$. 


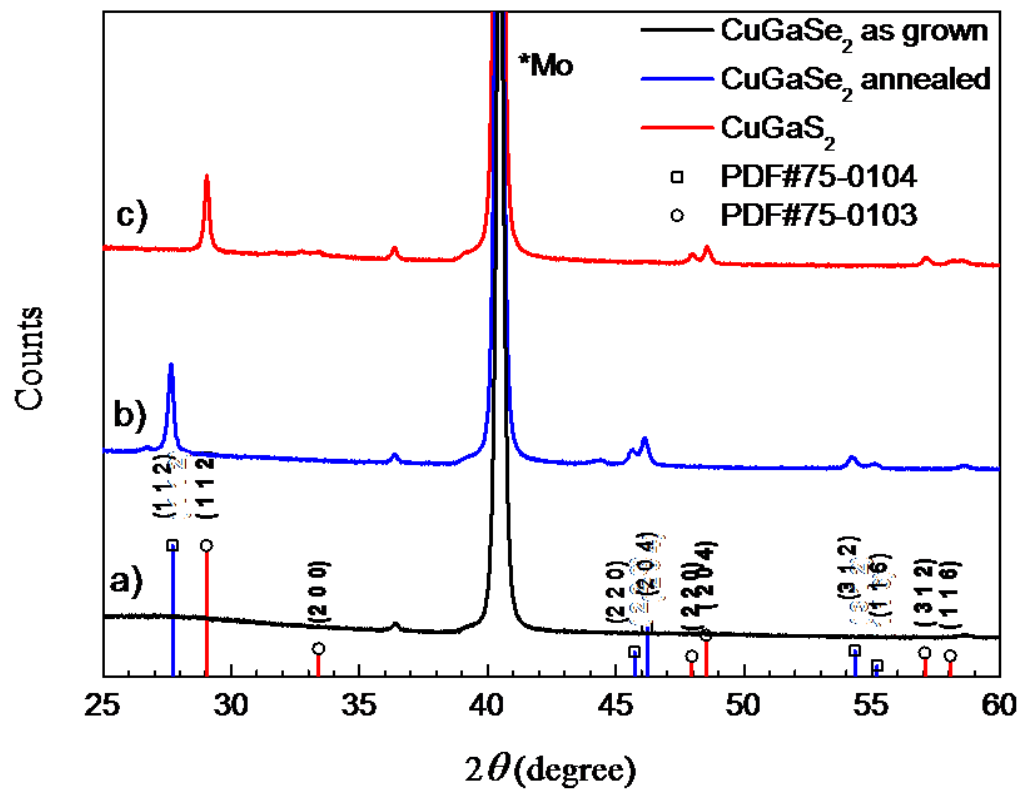

Figure 3.4. XRD patterns of $\mathrm{CuGaSe}_{2}$ and $\mathrm{CuGaS}_{2}$ films: (a) As deposited $\mathrm{CuGaSe}_{2}$ (b) After annealing at $450{ }^{\circ} \mathrm{C}$ in forming gas atmosphere and (c) After sulfurization in molecular Sulphur for 10 minutes at $400{ }^{\circ} \mathrm{C}$.

Figure 3.4 (c) presents the X-ray diffraction pattern of a sulfurized $\mathrm{CuGaSe}_{2}$ sample. The XRD peaks shift to higher angles with the sulfurization process. The main XRD peak corresponding to $\left(\begin{array}{lll}1 & 1 & 2\end{array}\right)$ diffraction peaks shifts from 27.9 to 29.0 degrees. Further, the peaks

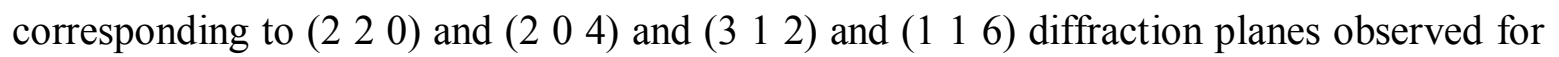
annealed $\mathrm{CuGaSe}_{2}$ films also shift to higher angles for sulfurized films. This XRD peaks match well with the JCPDS No. 75-0103 pattern corresponding to $\mathrm{CuGaS}_{2}$ films. This diffraction pattern confirms that, after sulfurization, Se atoms have been replaced by $\mathrm{S}$ atoms, and consequently $\mathrm{CuGaSe}_{2}$ thin films have been transformed into $\mathrm{CuGaS}_{2}[95,96,97]$.

Both $\mathrm{CuGaSe}_{2}$ and $\mathrm{CuGaS}_{2}$ films exhibit a tetragonal crystalline structure. The XRD patterns of $\mathrm{CuGaSe}_{2}$ and $\mathrm{CuGaS}_{2}$ thin films have a highly crystalline structure, offering the possibility of being used for photovoltaic devices with high conversion efficiency [98].

The crystallite size of electrodeposited and annealed $\mathrm{CuGaSe}_{2}$ and sulfurized $\mathrm{CuGaS}_{2}$ thin films was calculated applying the standard Debye-Scherrer formula to the (1 112$)$ diffraction peak: 


$$
D(\AA)=K \lambda / \beta \cos \theta
$$

Where $\beta$ is the full width at half maximum (FWHM), $\lambda$ is the X-ray wavelength having a value of $1.5418 \AA(\mathrm{CuK \alpha}), K$ is a proportionality constant ( $K=0.9$ was used) and $\theta$ is the Bragg angle at the centre of the peak. The crystallite size $D$ is the size of the crystal in the perpendicular direction to the reflecting planes [17]. It is noteworthy that the crystallite size is slightly bigger for $\mathrm{CuGaS}_{2}$ than for $\mathrm{CuGaSe}_{2}$ films, i.e. when $\mathrm{Se}$ is replaced by $\mathrm{S}$, the crystallinity of thin films improves. Table 3.1 summarizes the position, FWHM and crystallite sizes for the main ( $\left(\begin{array}{lll}1 & 1 & 2\end{array}\right)$ XRD peak for both selenized $\left(\mathrm{CuGaSe}_{2}\right)$ and sulfurized $\left(\mathrm{CuGaS}_{2}\right)$ samples.

\begin{tabular}{|c|c|c|c|}
\hline Samples & $\begin{array}{c}2 \theta \text { for (1 1 2) peak } \\
\text { (degree) }\end{array}$ & $\begin{array}{c}\text { FWHM } \\
\text { (degree) }\end{array}$ & $\begin{array}{c}\text { Crystallite size } \\
\text { (nm) }\end{array}$ \\
\hline $\begin{array}{c}\text { (a) As deposited- } \\
\mathrm{CuGaSe}_{2}\end{array}$ & - & - & - \\
\hline $\begin{array}{c}\text { (b) Annealed- } \\
\mathrm{CuGaSe}_{2}\end{array}$ & $27.794(1)$ & $0.20(1)$ & $43(2)$ \\
\hline $\begin{array}{c}\text { (c) } \mathrm{Sulphurized-}_{\mathrm{CuGaS}} \\
\mathrm{CuGa}_{2}\end{array}$ & $29.187(2)$ & $0.18(2)$ & $48(4)$ \\
\hline
\end{tabular}

Table 3.1. Calculated values for the crystallite size of $\mathrm{CuGaSe}_{2}$ and $\mathrm{CuGaS}_{2}$ thin films. Uncertainties appear in parentheses.

\subsubsection{Scanning Electron Microscopy analysis}

Figure 3.5 shows the SEM images of the surface morphology for as-deposited, annealed and sulfurized $\mathrm{CuGaSe}_{2}$ thin films on Mo-coated substrates. Clusters of about 200 $\mathrm{nm}$ made by aggregation of smaller grains can be observed for as-deposited $\mathrm{CuGaSe}_{2}$ films in Figure 3.5 (a), (b), (c) and (d) show the SEM images for the annealed $\mathrm{CuGaSe}_{2}$, sulfurized $\mathrm{CuGaS}_{2}$ and $\mathrm{CuGaS}_{2}: \mathrm{Cr}$ thin films respectively. An aggregation process of grains seems to have occurred and the observed grains are now larger than $400 \mathrm{~nm}$ in both cases. The coalescence of grains increases with either annealing processes. These results are compatible with the XRD results. According to the XRD analysis, the as-deposited samples have low crystallinity as no diffraction peaks are observed. However, after the two annealing processes 
mentioned here the films the X-Ray diffraction peaks appear, which means that the films became crystalline after annealing. According to SEM measurements the thickness of both selenized $\left(\mathrm{CuGaSe}_{2}\right)$ and sulfurized $\left(\mathrm{CuGaS}_{2}\right)$ films is about $1 \mu \mathrm{m}$.
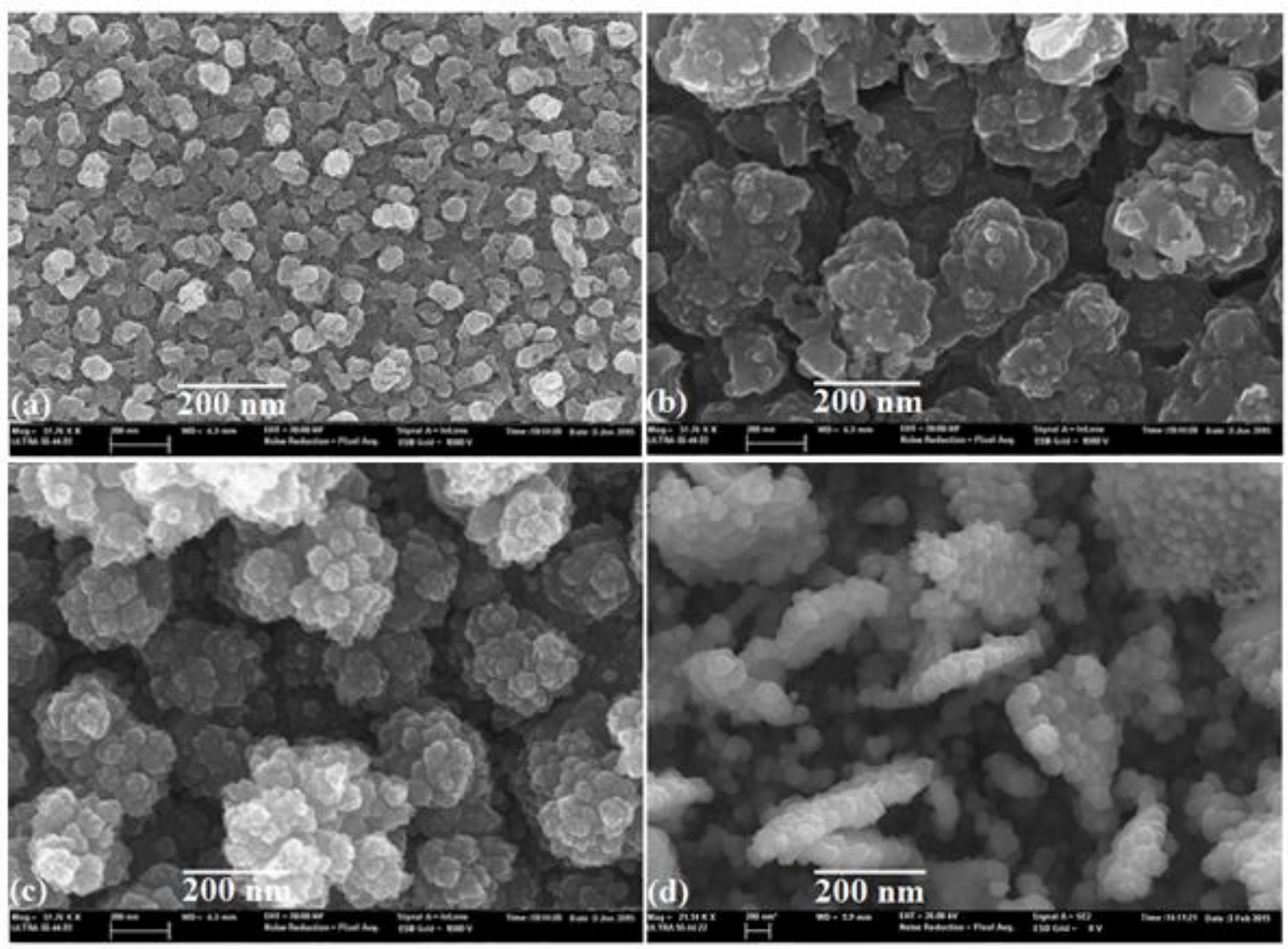

Figure 3.5. SEM images of surface morphology of $\mathrm{CuGaSe}_{2}$ and $\mathrm{CuGaS}_{2}$ films deposited on Mo electrodes at -0.6 during 30 min: (a) as-deposited $\mathrm{CuGaSe}_{2}$, (b) $\mathrm{CuGaSe}_{2}$ annealed for $40 \mathrm{~min}$ at $450{ }^{\circ} \mathrm{C}$ in forming gas atmosphere, (c) $\mathrm{CuGaS}_{2}$ films obtained after sulfurization of electrodeposited $\mathrm{CuGaSe}_{2}$ films and (d) $\mathrm{CuGaS}_{2}$ doped with $\mathrm{Cr}$.

\subsubsection{Energy dispersive spectroscopy analysis}

Energy Dispersive X-ray Spectroscopy was used to determine the composition of deposited $\mathrm{CuGaSe}_{2}$ and $\mathrm{CuGaS}_{2}$ films. Figures 3.6 a) and b) show the EDS spectra of annealed $\mathrm{CuGaSe}_{2}$ and $\mathrm{CuGaSe}_{2}$ films doped with chrome. Main X-ray peaks belong to $\mathrm{Cu}$, $\mathrm{Ga}$, Se and Mo, which come from the substrate. In Cr-doped $\mathrm{CuGaSe}_{2}$ films two lines located at 5.5 and $6.0 \mathrm{keV}$, respectively, support the presence of chrome in these samples. After 
sulfurization (figure $3.6 \mathrm{c}$ ) the lines related to Se are reduced, the conversion of selenium into sulfur after the sulfurization process becomes evident. Only a residual part of selenium (lower that $1 \%$ ) remains after 10 -minutes sulfurization.

The quantification of the EDS analysis is shown in Table 3.2. The measured $\mathrm{Se} /(\mathrm{Cu}+\mathrm{Ga})$ ratio for as-deposited $\mathrm{CuGaSe}_{2}$ films is 1.02 , while for selenized $\mathrm{CuGaSe}_{2}$ films it is 1.07 , meaning that both samples have a slight deficit of Ga. After sulfurization, most of the selenium is substituted by sulfur and only $0.9 \%$ of Se remains. The $(\mathrm{S}+\mathrm{Se}) /(\mathrm{Cu}+\mathrm{Ga})$ is practically the same. Thus, the results obtained show that the samples are stoichiometric.

\begin{tabular}{|c|c|c|c|c|c|}
\hline Samples id. & $\% \mathrm{Cu}$ & $\% \mathrm{Ga}$ & $\% \mathrm{Se}$ & $\% \mathrm{~S}$ & $(\mathrm{Se}+\mathrm{S}) /(\mathrm{Cu}+\mathrm{Ga})$ \\
\hline $\begin{array}{c}\text { As deposited }- \\
\mathrm{CuGaSe}_{2}\end{array}$ & 26 & 24 & 50 & -- & 1.00 \\
\hline $\begin{array}{c}\text { Annealed }- \\
\mathrm{CuGaSe}_{2}\end{array}$ & 26 & 22 & 52 & -- & 1.08 \\
\hline $\begin{array}{c}\text { Sulphurized }- \\
\mathrm{CuGaS}_{2}\end{array}$ & 26 & 22 & $>1$ & 51.0 & 1.08 \\
\hline
\end{tabular}

Table 3.2 EDS analysis of elemental composition of $\mathrm{CuGaSe}_{2}$ and $\mathrm{CuGaS}_{2}$ films. EDS uncertainties is estimated to be about $1 \%$. 


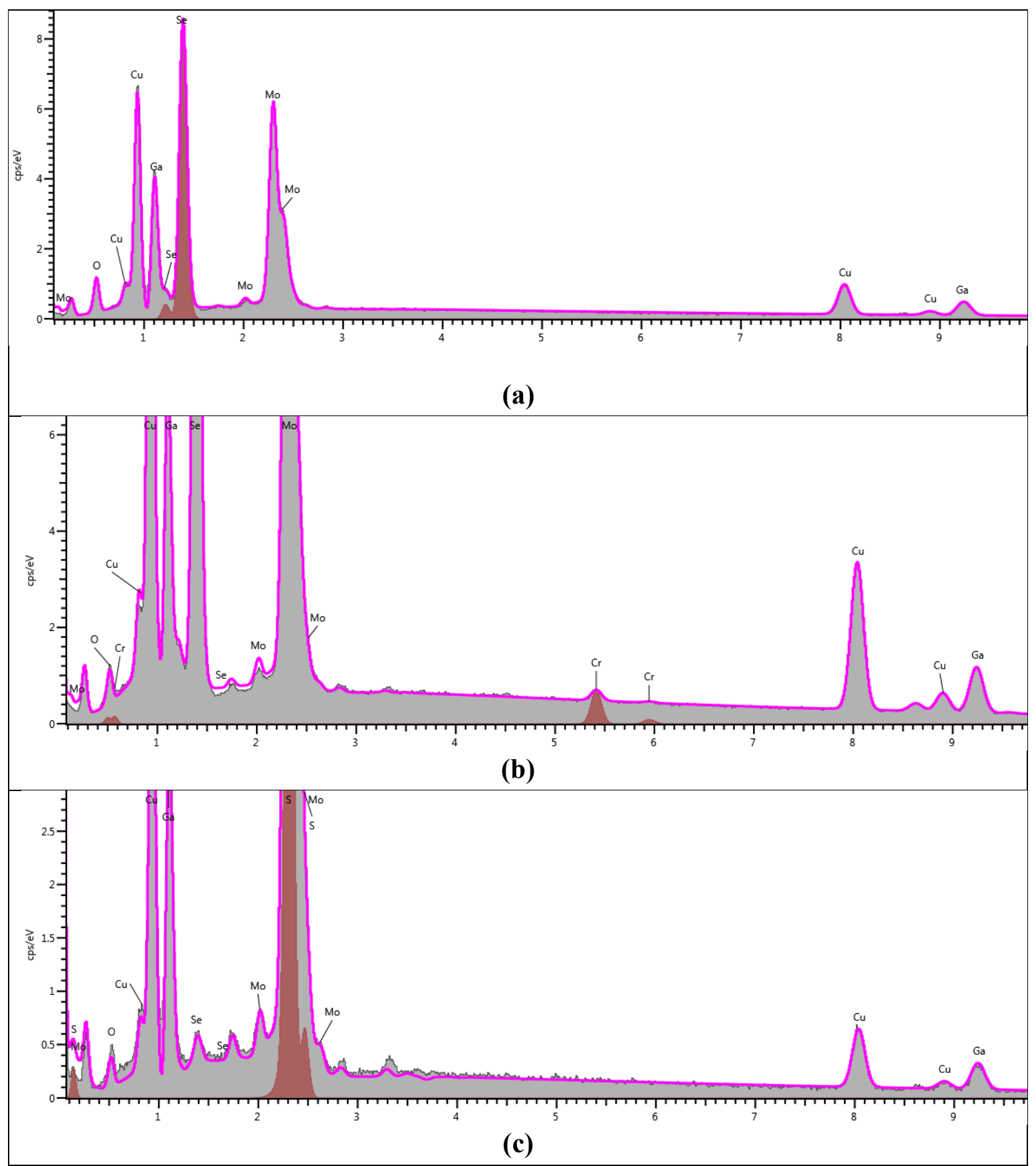

Figure 3.6. EDS spectrum for: a) annealed $\mathrm{CuGaSe}_{2}$ b) $\mathrm{CuGaSe}_{2}$ doped by $\mathrm{Cr}$ : and c) sulfurized $\mathrm{CuGaS}_{2}$ thin films.

The content of chrome in doped films always remains between 1 and $2 \%$, irrespective of the amount of $\mathrm{Cr}^{3+}$ added to the starting electrolyte. That means that the ratio $\mathrm{Cr}$ :Ga ranges from 
4 to $8 \%$. It is noteworthy that the sensitivity of EDS measurements is estimated to be about $1 \%$.

\subsubsection{Atomic Force Microscopy analysis}

The surface morphology and the roughness of the $\mathrm{CuGaSe}_{2}$ and $\mathrm{CuGaS}_{2}$ as analysed by Atomic Force Microscope is presented in Figure 3.7, 2D and figure 3.8, 3D images. It can be seen that small grains are grouped to form by cauliflower-like clusters. According to Atomic Force Microscopy, the roughness of the film increases through annealing, for this reason the density of grain boundaries should be low (big grains) to reduce the recombination rate and improve the quality of the films and cell performance, which is favourable for solar cell applications as a rough surface will trap more light [99].
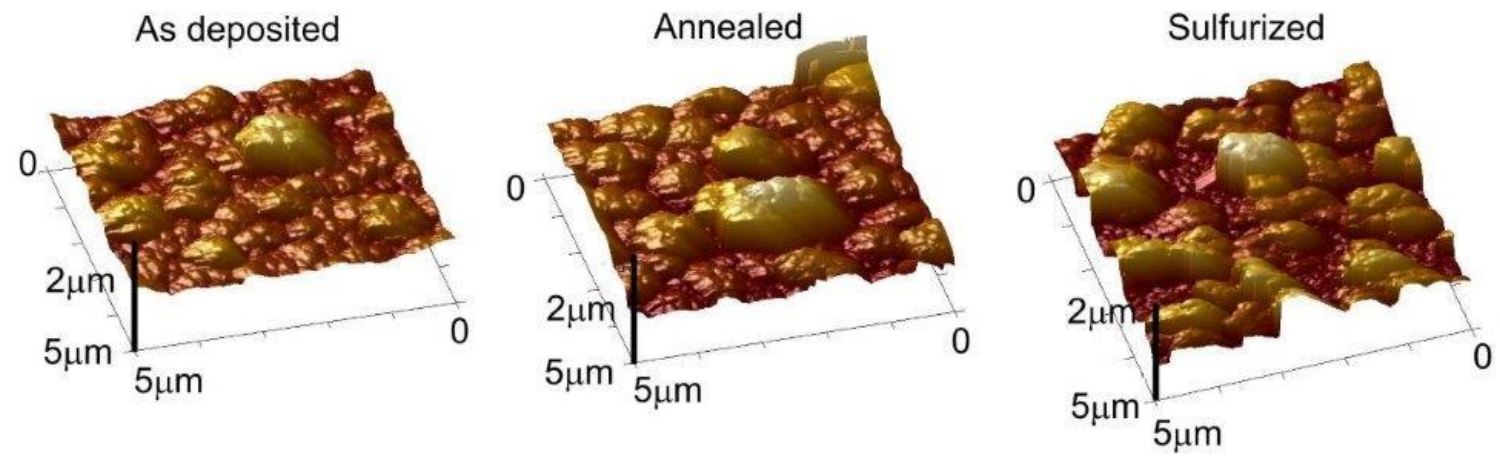

Figure 3.7. 3D AFM micrograph of as-deposited $\mathrm{CuGaSe}_{2}$ layers (a) as deposited (b), annealed in selenium and (c) sulfurized.
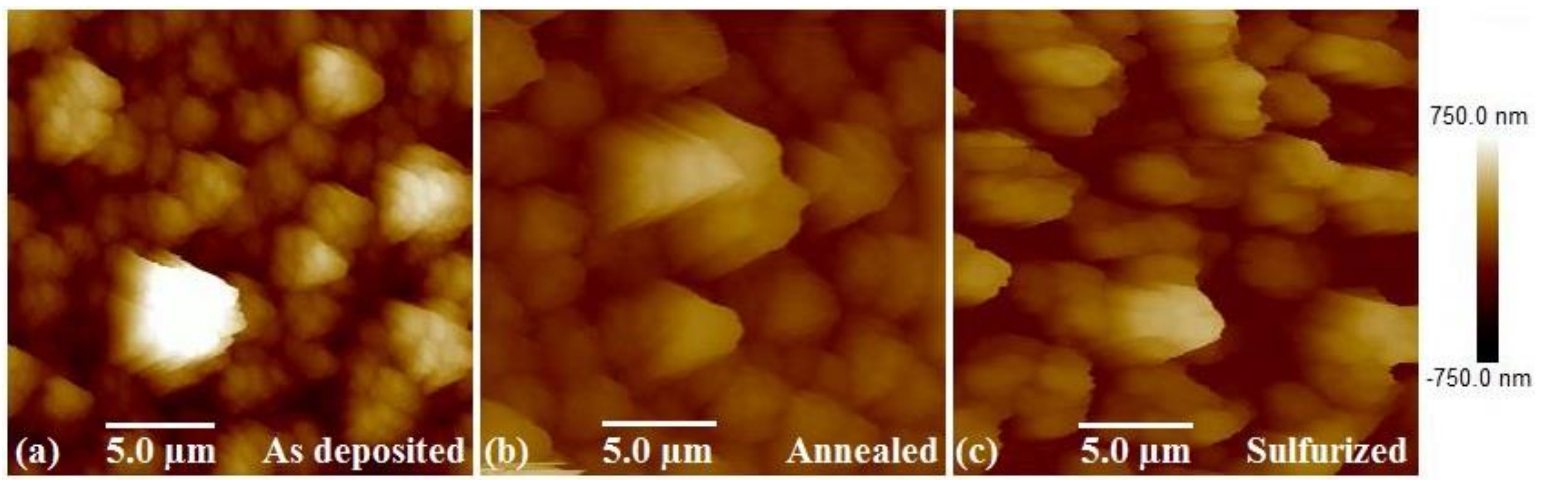

Figure 3.8. 2D AFM micrograph of as-deposited $\mathrm{CuGaSe}_{2}$ layers (a) as deposited (b), annealed in selenium and (c) sulfurized. 
Table 3.3 shows the characterization results performed by Atomic Force Microscopy. A linear relationship between the roughness and the grain size for all studied films was observed, when the roughness increases, the grain size also increases.

\begin{tabular}{|c|c|c|}
\hline Sample id. & Roughness (nm) & Grain size (nm) \\
\hline As deposited - CuGaSe2 & 234 & 160 \\
\hline Annealed - CuGaSe2 & 336 & 334 \\
\hline Sulphurized - $\mathrm{CuGaS}_{2}$ & 422 & 573 \\
\hline
\end{tabular}

Table 3.3 AFM characterization of $\mathrm{CuGaSe}_{2}$ and $\mathrm{CuGaS}_{2}$ thin films.

The as-deposited $\mathrm{CuGaSe}_{2}$ roughness is $234 \mathrm{~nm}$ and the grain size is $160 \mathrm{~nm}$. After annealing the roughness of the films increases from 234 to $336 \mathrm{~nm}$ and the grain size also increases 2 times from 160 to $334 \mathrm{~nm}$. The sulfurization process also results in higher values for the roughness increasing to $422 \mathrm{~nm}$, and for the grain size grows up to $573 \mathrm{~nm}$. The increase of the grain size observed after the annealing process is a consequence of the recrystallization process occurring during the annealing process and agrees with the increase of crystallite sizes observed by XRD.

\subsection{Optical analysis}

The optical transmittance and absorption spectra were recorded for $\mathrm{CuGaSe}_{2}$ and $\mathrm{CuGaS}_{2}$ films electrodeposited on a conductive transparent ITO substrate in order to evaluate the optical energy bandgap $(\mathrm{Eg})$. In fact, the fundamental absorption edge in semiconductor material can be used to determine the energy bandgap according to the relationship,

$$
(\alpha h v)^{2}=\mathrm{A}(h v-\mathrm{E} g)^{\mathbf{n}} / h v
$$

where $\alpha$ is the absorption coefficient of the material, hv is the photon energy $(\mathrm{eV}), v$ is the photon frequency, $h$ is the Plank's constant, Eg is the optical bandgap of the material, A is a constant which is related to the effective masses of both electron and holes in the bands and $\mathrm{n}$ being a constant associated with the nature of the optical transition in the material (direct allowed, direct forbidden, indirect allowed or indirect forbidden transitions). For a direct allowed transition or direct bandgap such as $\mathrm{CuGaSe}_{2}$ and $\mathrm{CuGaS}_{2}, \mathrm{n}$ assumes the value of 
$1 / 2$ and then the plot of $(\alpha h v)^{2}$ versus photon energy $(h v)$ forms a straight line whose intercept with the $(\alpha h v)^{2}=0$ axis yields the value of the energy bandgap (Eg) $[100,101]$.

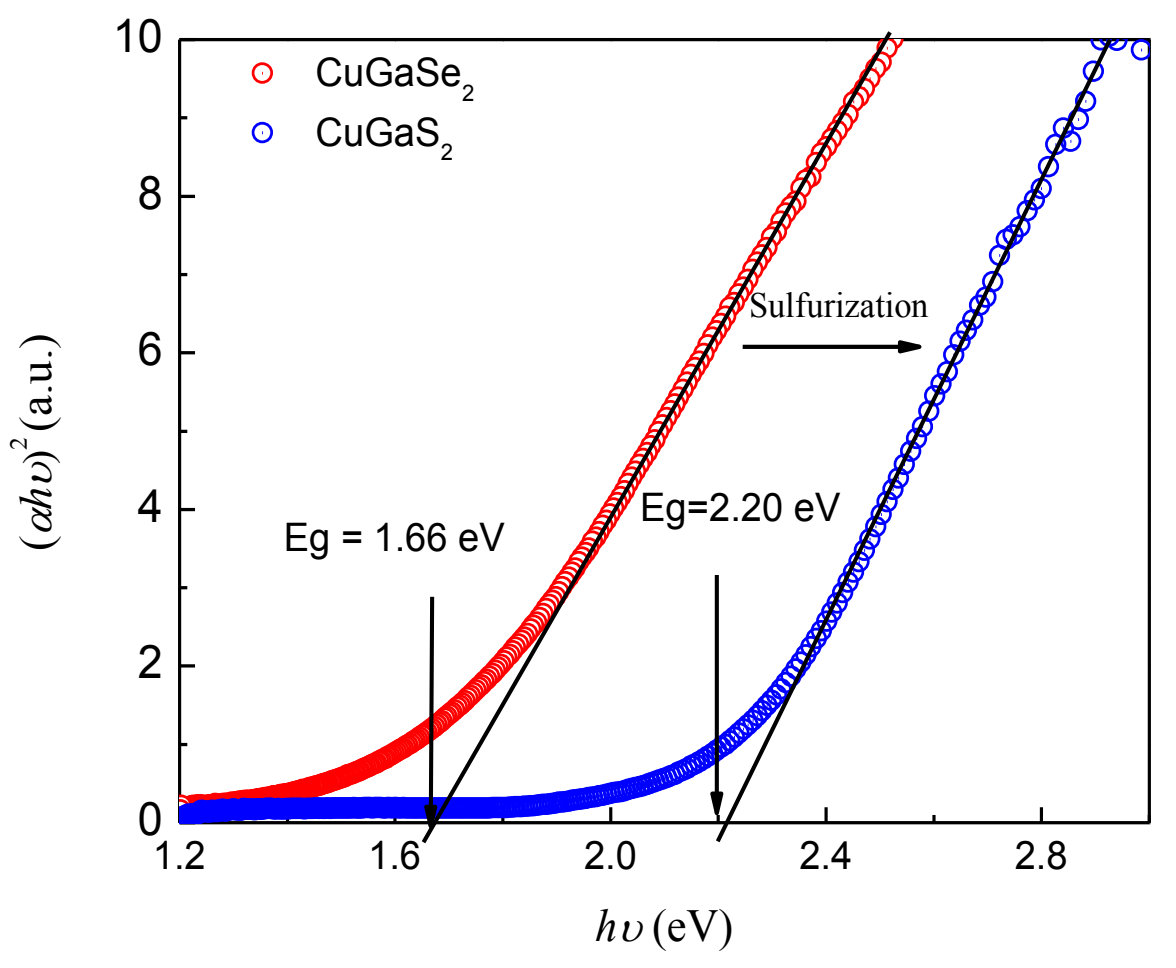

Figure 3.9. Plot of $(\alpha h v)^{2}$ vs. Photon energy for $\mathrm{CuGaSe}_{2}$ and $\mathrm{CuGaS}_{2}$ thin films.

\subsubsection{Energy bandgap of $\mathrm{CuGaSe}_{2}, \mathrm{CuGaS}_{2}$ thin films}

Figure 3.9 displays $(\alpha h v)^{2}$ versus photon energy $h v$ for $\mathrm{CuGaSe}_{2}$ and $\mathrm{CuGaS}_{2}$ thin films. As can be seen, the intercept with the $(\alpha h v)^{2}=0$ axis yields 1.66 and $2.20 \mathrm{eV}$ for $\mathrm{CuGaSe}_{2}$ and $\mathrm{CuGaS}_{2}$ thin films, respectively. These values are very close to those reported for $\mathrm{CuGaSe}_{2}$ and $\mathrm{CuGaS}_{2}$, respectively. The shift of the optical bandgap to higher energies confirms again the transformation of $\mathrm{CuGaSe}_{2}$ to $\mathrm{CuGaS}_{2}$ as a consequence of the above mentioned 10 minutes sulfurization process. 


\subsubsection{Optical absorption of $\mathrm{CuGaSe}_{2}, \mathrm{CuGaS}_{2}$ and $\mathrm{CuGaS}_{2}: \mathrm{Cr}$ thin films}

Figure 3.10 compares the normalized absorbance for $\mathrm{CuGaSe}_{2}, \mathrm{CuGaS}_{2}$ and $\mathrm{CuGaS}_{2}: \mathrm{Cr}$ thin films related to the wavelength. The blue shift of the onset of the absorbance (or bandgap) in $\mathrm{CuGaS}_{2}$ films with respect to $\mathrm{CuGaSe}_{2}$ films is evident. However, the absorbance for $\mathrm{CuGaS}_{2}$ : $\mathrm{Cr}$ films exhibits an additional characteristic with respect to undoped $\mathrm{CuGaS}_{2}$ films, namely an absorption band below the bandgap. The broad absorption band observed for $\mathrm{CuGaS}_{2}: \mathrm{Cr}$ is centred at $760 \mathrm{~nm}(1.63 \mathrm{eV})$ and can be assigned to a sub-band absorption band related to Cr-doping. According to theoretical studies, $\mathrm{Ga}^{3+}$ substitution by transition metals into $\mathrm{CuGaS}_{2}$ chalcopyrite structures would give rise to a partially filled absorption band, which will favour the promotion of electrons from the valence band to the absorption band through a two-photon absorption process [102].

Among the several strategies proposed for thin film solar cells the concept of intermediateband solar cells has caught a great deal of attention in recent. The inserted intermediate band gap energy position neither overlaps the valence band nor the conduction band (CB), the IB not only absorbs one photon of higher energy than the band gap width $\left(\mathrm{E}_{\mathrm{g}}\right)$ but also promotes the absorption of two lower energy photons, which, respectively, promote one electron from the valence band (VB) to the IB and from the IB to the CB [103]. This intermediate band associated to $\mathrm{Cr}$-doping in $\mathrm{CuGaS}_{2}$ may allow a higher current to be obtained at the voltage corresponding to the energy gap value; increasing the overall efficiency of thin film solar cells. 


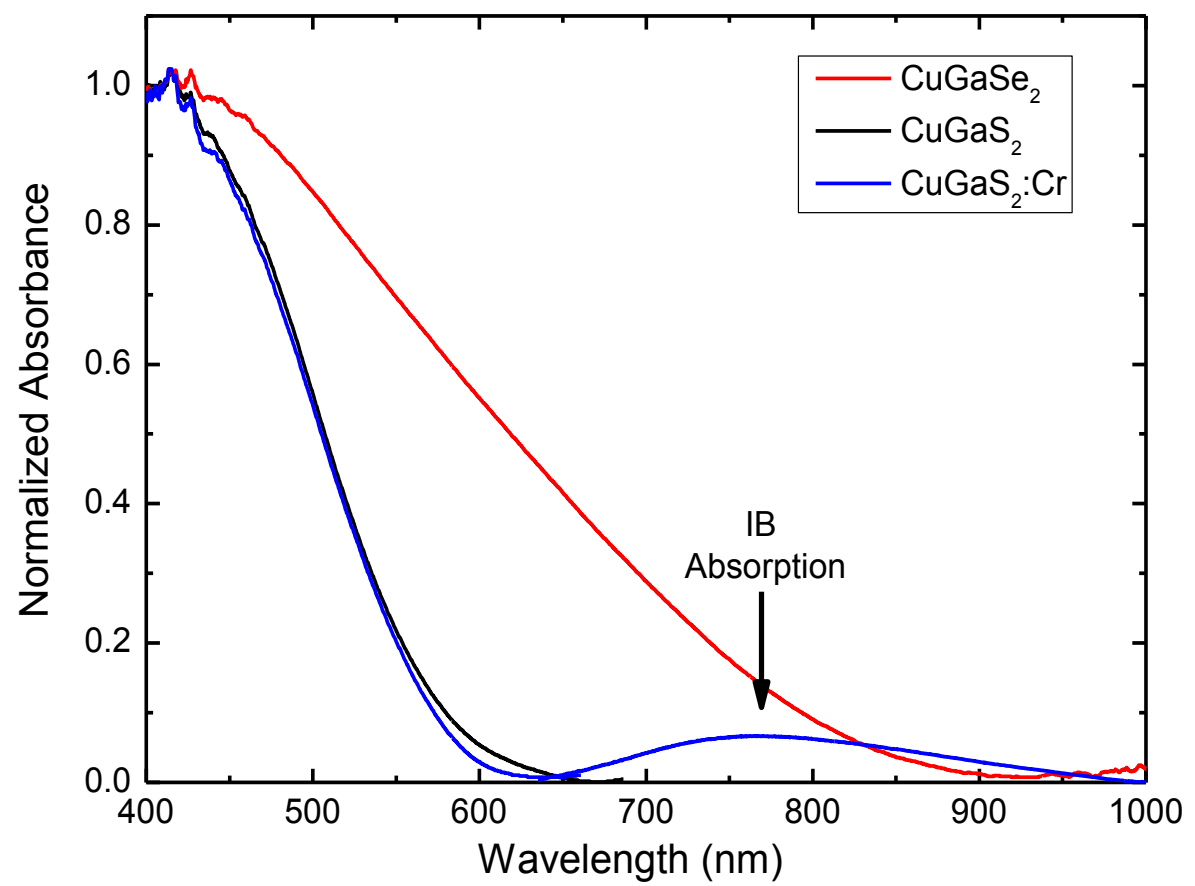

Figure 3.10. Comparison of the absorbance of $\mathrm{CuGaSe}_{2}, \mathrm{CuGaS}_{2}$ and $\mathrm{CuGaS}_{2}: \mathrm{Cr}$ thin films. The broad absorption band observed for $\mathrm{CuGaS}_{2}: \mathrm{Cr}$, centred at $760 \mathrm{~nm}$ is attributed to Cr-related intermediate band.

\section{Conclusion}

$\mathrm{CuGaSe}_{2}$ and $\mathrm{CuGaS}_{2}$ thin films suitable for solar cells were successfully prepared by electrodeposition on ITO and Mo-coated glass substrates. $\mathrm{CuGaSe}_{2}$ thin films were deposited from an aqueous electrolyte containing the suitable precursors. Annealing in Se atmosphere at $450{ }^{\circ} \mathrm{C}$ dramatically improves the crystallinity of $\mathrm{CuGaSe}_{2}$ films. Understanding the mechanism of $\mathrm{CuGa}(\mathrm{S}, \mathrm{Se})_{2}$ formation is an important step in improving production and device efficiencies. $\mathrm{CuGaS}_{2}$ films were obtained by subsequent sulfurization at $450{ }^{\circ} \mathrm{C}$ in presence of molecular sulfur of as-deposited $\mathrm{CuGaSe}_{2}$ layers. Crystallite sizes of about 43-48 nm were obtained for both thermally treated $\mathrm{CuGaSe}_{2}$ and $\mathrm{CuGaS}_{2}$ films.

When annealing in sulfur atmosphere two processes take place, conversion of Se in to $\mathrm{S}$ leading the formation of $\mathrm{CuGaS}_{2}$ thin films and improvement of its crystallinity. The replacement of Se by $\mathrm{S}$ is inferred by the changes observed in the $\mathrm{X}$ ray diffractogram and by the shift of the optical bandgap from $1.66 \mathrm{eV}$ for $\mathrm{CuGaSe}_{2}$ to $2.20 \mathrm{eV}$ for $\mathrm{CuGaS}_{2}$. 
Cr-doping was achieved by adding $\mathrm{Cr}^{3+}$ to the starting electrolyte. The effectiveness of $\mathrm{Cr}$ doping was inferred from the presence of $\mathrm{Cr}$ in $\mathrm{CuGaS}_{2}$ layers and the optical detection of a sub-bandgap absorption band. According to EDS measurements the amount of Ga atoms substituted by $\mathrm{Cr}$ ranges from 4 to $8 \%$. Further, an intermediate absorption band centred at about $1.63 \mathrm{eV}$ above the valence band is observed in $\mathrm{CuGaS}_{2}: \mathrm{Cr}$ films. The intermediate band in $\mathrm{CuGaS}_{2}: \mathrm{Cr}$ films would allow the absorption of photons with energy higher than the bandgap $\left(\mathrm{E}_{\mathrm{g}}\right)$ and also the absorption of two lower energy photons, which promote electrons from the VB to the IB and from the IB to the CB, respectively. Therefore this intermediate band associated to $\mathrm{Cr}$-doping in $\mathrm{CuGaS}_{2}$ may allow a higher current to be obtained at the voltage corresponding to the energy gap value, so increasing the overall efficiency of the solar cell. 
This page intentionally left blank 


\section{Chapter 4}

\subsection{Introduction of Cadmium sulfide (CdS) and Cadmium zinc sulfide $(\mathrm{CdZnS})$ thin films.}

\subsubsection{Cadmium sulfide (CdS) as a buffer layer}

$\mathrm{CdS}$ is an n-type semiconductor. It is one of the most extensively investigated semiconductors in the thin-film form and a large variety of deposition techniques have been utilized to obtain device quality layers of CdS [104]. It is a heterojunction partner in CIGS solar cells with a bandgap of $2.42 \mathrm{eV}$. Cross section images of the $\mathrm{CuInSe} / \mathrm{CdS}$ interface show that CdS can grow epitaxial on CIS [105]. It also serves as a window layer that allows the light to pass through it with relatively small absorption. Also, because the carrier density in $\mathrm{CdS}$ is much larger than in CIGS, the depletion field resides mostly in the CIGS layer where electron-hole pairs are generated.

CdS films are usually grown by chemical bath deposition (CBD). The crystal structure can be varied depending upon the deposition parameters [106]. CdS deposited by the CBD route has wurtzite crystal structure with the c axis perpendicular to the substrate plane.

Deposition of CdS heterojunction partner layer on the CIGS absorber is generally carried out in an alkaline aqueous solution of $\mathrm{pH}>9$, consisting of cadmium salt (CdSO4), a complexing agent $(\mathrm{NH} 4 \mathrm{OH})$ and a sulfur precursor thiourea, $\mathrm{SC}(\mathrm{NH} 2)_{2}$. The complexing agent slows down the reaction and prevents the formation of $\mathrm{Cd}(\mathrm{OH})_{2}$. The concentration of thiourea is usually much higher than that of the metal precursor. The deposition is carried out in the temperature range of 60 to $80{ }^{\circ} \mathrm{C}$ where thiourea hydrolyzes and decomposes releasing $\mathrm{S}^{2-}$ ions. The net reaction for the formation of $\mathrm{CdS}$ is,

$\mathrm{Cd}(\mathrm{NH} 3) 4^{2+}+\mathrm{SC}(\mathrm{NH} 2)_{2}+2 \mathrm{OH}^{-} \rightarrow \mathrm{CdS}+\mathrm{H} 2 \mathrm{NCN}+4 \mathrm{NH}_{3}+2 \mathrm{H}_{2} \mathrm{O}$

There are several benefits of the CdS layer:

1. CBD deposition of $\mathrm{CdS}$ provides conformal coverage of the rough polycrystalline absorber surface. 
2. Cd also diffuses to a certain extent into the Cu-poor surface layer of the absorber material, where it possibly forms $\mathrm{CdCu}$ donors, thus providing additional positive charges that enhance the type inversion of the heterojunction partner (CdS)/absorber interface [107].

3. The chemical bath removes the natural oxide from the film surface thus, it regenerates positively charged surface states and, as a consequence, the natural type inversion at the heterojunction partner/ absorber interface.

4. The layer protects against damages and chemical reactions resulting from subsequent $\mathrm{ZnO}$ deposition process.

5. From the electrical point of view, the CdS layer optimizes the band alignment of the device [108] and builds a sufficiently wide depletion layer that minimizes tunneling and establishes a higher contact potential that allows higher open circuit voltage [109].

\subsubsection{Cadmium Zinc Sulfide $(\mathrm{CdZnS})$ window layer}

Cadmium zinc sulfide $(\mathrm{CdZnS})$ ternary compounds have long been known to be suitable materials for thin-film photovoltaic device applications because of their high optical absorption coefficients. CdZnS thin films have been prepared by a variety of techniques, which include evaporation [110], spray pyrolysis [111], chemical bath deposition [112], electrodeposition [113,114], metal-organic chemical vapor deposition (MOCVD) [115]. Among various deposition techniques, chemical bath deposition yields stable, uniform, adherent and hard films with good reproducibility by a relatively simpler process forms a very compact, homogenous and without pin holes $[116,117]$.

Thin film solar cells with copper indium gallium selenide $\left(\mathrm{CIGSe}_{2}\right)$ and copper indium gallium sulfide $\left(\mathrm{CIGS}_{2}\right)$ absorber have achieved high efficiency in recent years due to the $\mathrm{CdZnS}$ window layer for solar cells application to improve the collection of short-wavelength photons. Cadmium zinc sulfide (CdZnS) thin films have been widely used as a wide bandgap window material in photoconductive devices and in heterojunction thin films solar cells. The band gap of this ternary material can be from 2.42 to $3.50 \mathrm{eV}$, depending on the $\mathrm{Cd} / \mathrm{Zn}$ ratio $[118,119,120]$. 
The use of these materials in photovoltaic device applications requires better controlling the procedure parameters during the growth and furthermore, defined and reliable modeling of their electronic and optical properties as a function of their composition. Due to its simplicity and its cheap economical experimental setup required for thin film deposition, $\mathrm{CBD}$ is a suitable method to obtain low-cost CdZnS thin films with the optimal features for photovoltaic device applications [121].

In solar cell systems, where CdS films have been demonstrated to be effective, the replacement of CdS with the higher band gap ternary $\mathrm{CdZnS}$ has led to a decrease in window absorption losses, and has significant increase in short circuit current in solar cell $[122,123]$. In the past, efforts have been made to increase CdS film conductivity by doping with indium [124] not significant records were found about $\mathrm{Zn}$ doped with CdS films.

In the present work, we present the synthesis and characterization of $\mathrm{CdZnS}$ thin films with significant improvement in photocurrent generation under visible light illumination and optical characteristics to be used as buffer and/or window material in $\mathrm{Cu}$ (In, Ga) $\mathrm{Se}_{2}$ and CdTe solar cells.

\subsubsection{Mechanism of $\mathrm{Cd}_{1-\mathrm{x}} \mathrm{Zn}_{\mathrm{x}} \mathrm{S}$ thin films formation}

The reaction procedure for the synthesis $\mathrm{Cd}_{1-\mathrm{x}} \mathrm{Zn}_{\mathrm{x}} \mathrm{S}$ thin films may be described by the following steps [125]

Ammonium formation is given by:

$\mathrm{NH}_{3}+\mathrm{H}_{2} \mathrm{O} \leftrightarrow \mathrm{NH}_{4}^{+}+\mathrm{OH}^{-}$

The method which used to prepare cadmium sulfide $(\mathrm{CdS})$ includes the reaction of cadmium ion $\left(\mathrm{Cd}^{2+}\right)$ with sulfide ions $\left(\mathrm{S}^{-2}\right)$. Sulfide ions was found in solution from thiourea as shown in the equations 2,3 below:

$\left(\mathrm{NH}_{2}\right)_{2} \mathrm{CS}+\mathrm{OH}^{-} \leftrightarrow \mathrm{SH}^{-}+\mathrm{CN}_{2} \mathrm{H}_{2}+\mathrm{H}_{2} \mathrm{O}$

$\mathrm{SH}^{-}+\mathrm{OH} \leftrightarrow \mathrm{S}^{2-}+\mathrm{H}_{2} \mathrm{O}$

Dissolving cadmium acetate and zinc acetate in water made both cadmium and zinc ions are available in solution indirectly by the formation of complexes of those ions as shown in the equation below: 
$\mathrm{Cd}(\mathrm{OH})_{2}+4 \mathrm{NH}_{2} \mathrm{OH} \rightarrow\left[\mathrm{Cd}\left(\mathrm{NH}_{3}\right)_{4}\right]^{2+}$

$\mathrm{Cd}(\mathrm{OH})_{2}+4 \mathrm{NH}_{2} \mathrm{OH} \rightarrow\left[\mathrm{Cd}\left(\mathrm{NH}_{3}\right)_{4}\right]^{2+}$

$\mathrm{Zn}_{2}+2 \mathrm{OH}^{-} \leftrightarrow \mathrm{Zn}(\mathrm{OH})_{2} \downarrow$

$\mathrm{Zn}(\mathrm{OH})_{2}+4 \mathrm{NH}_{2} \mathrm{OH} \rightarrow\left[\mathrm{Zn}\left(\mathrm{NH}_{3}\right)_{4}\right]^{2+}$

$\left[\mathrm{Cd}\left(\mathrm{NH}_{3}\right)_{4}\right]^{2+}$ and $\left[\mathrm{Zn}\left(\mathrm{NH}_{3}\right)_{4}\right]^{2+}$ are called cadmium and zinc tetra - amine complex ions, respectively.

Each three of these source ions (eqs. 3, 5, 7) are combined in the reaction leading to the formation of $\mathrm{CdZnS}$ as shown in the equation below:

$(1-x)\left[C d\left(\mathrm{NH}_{3}\right)^{2+}{ }_{4}\right]+x\left[\mathrm{Zn}\left(\mathrm{NH}_{3}\right)^{2+}{ }_{4}\right]+\mathrm{S}^{2-}+\mathrm{NH}_{3} \rightarrow \mathrm{Cd}_{1-x} \mathrm{Zn} n_{x} \mathrm{~S}+$ wast

\subsection{Preparation of $\mathrm{Cd}_{1-\mathrm{x}} \mathrm{Zn}_{\mathrm{x}} \mathrm{S}$ thin films}

$\mathrm{Cd}_{1-\mathrm{x}} \mathrm{Zn}_{\mathrm{x}} \mathrm{S}$ thin films were deposited using the chemical bath deposition (CBD) technique. Indium thin oxide (ITO) were cleaned in an ultra-sonic bath degreased by ethanolacetone-ethanol and de-ionized water respectively. The time taken for each step was about 15 minutes. Degreased glasses were cleaned by dry nitrogen (N2) gas. The bath parameters were similar to those used elsewhere [126]. Various zinc/cadmium ratios $(x=0 \%, 3 \%, 5 \%$ and $10 \%$ ) were used in this experiment. The starting materials used were $\mathrm{CdSO}_{4}$ as $\mathrm{Cd}^{2+}$ ion source, $\mathrm{ZnSO}_{4}$ as $\mathrm{Zn}^{2+}$ ion source, thiourea as an $\mathrm{S}^{2-}$ ion source and triethenolamine (TEA) as a complexing agent to control the $\mathrm{Cd}^{2+}$ and $\mathrm{Zn}^{2+}$ ion concentrations. An alkaline solution of ammonia was used to adjust $\mathrm{pH}$ of the reaction mixture. All the chemicals used were Sigma Aldrich Analytical Reagent grade.

The $\mathrm{CBD}$ process involves a controllable chemical reaction at a low rate, by adjusting the $\mathrm{pH}$ value and temperature of the working solution. The $\mathrm{pH}$ value of working solution was adjusted by a $\mathrm{pH}$ meter and kept in between 9.5 and 10 for different deposition time (15-60 min.). The experimental arrangement consists of a special substrate holder, which is attached to a motor having a constant speed of $60 \mathrm{rpm}$ throughout the reaction. The temperature of chemical bath consisted of required amount of distilled deionized water was adjusted at $70 \pm 5$ ${ }^{\circ} \mathrm{C}$ to achieve the desired maximum temperature of $\mathrm{CdZnS}$ deposition in the chemical bath, while magnetic stirrer was applied to promote ion-by-ion heterogeneous growth on the 
substrate. The $\mathrm{Cd}_{1-\mathrm{x}} \mathrm{Zn}_{\mathrm{x}} \mathrm{S}$ samples were prepared on carefully cleaned glass substrates and tin oxide (ITO) coated glass substrates. Cleaning substrates procedure is reported elsewhere [127] and it is important in deposition of thin films. After deposition the substrates were removed from the chemical bath, cleaned in double distilled water and dried.

The crystallographic structure of the $\mathrm{Cd}_{1-\mathrm{x}} \mathrm{Zn}_{\mathrm{x}} \mathrm{S}$ films were investigated by $\mathrm{X}$-Ray Diffraction (XRD) using a Rigaku Ultima IV diffractometer in the Bragg-Brentano (BB) and parallel beam $(\mathrm{PB})$ configurations using $\mathrm{Cu}-\mathrm{K} \alpha$ radiation $(\lambda=1.54060 \AA)$ and a scanning 2 theta angle from $20^{\circ}$ to $60^{\circ}$. The chemical composition analysis, surface morphology, and the topography were characterized using energy dispersive spectroscopy (EDS), Field Emission Scanning Electron Microscopy (FESEM) of model Zeiss ULTRA 55 equipped with In-Lens and secondary electrons detectors and atomic force microscopy (AFM) Bruker Multimode 8 AFM Nano scope V controller, respectively, high-resolution transmission electrons microscopy (HRTEM, 200 KV) JEOL Model: JEM-2100F were used to study the crystalline structure and morphology of nanowire arrays.

The optical properties of $\mathrm{Cd}_{1-\mathrm{x}} \mathrm{Zn}_{\mathrm{x}} \mathrm{S}$ films were measured at room temperature by using $\mathrm{UV}$ -VIS- IR spectrophotometer at wavelength within the range (300-1050) nm.

The photo electrochemical properties of the samples were measured using a high output photo electrochemical set up described elsewhere [128,129]. In brief, The PEC measurements were performed in a quartz cell to facilitate the light to the photo electrode surface. The superficial area of the working electrode is $0.25 \mathrm{~cm}^{2}$ using $0.1 \mathrm{M}$ of KCL electrolyte. The Chronoamperometry curves of the thin films were obtained at $+0.1 \mathrm{~V}$ both in dark and under illumination by using the Auto lab potentiostat PGSTAT302N [130] with a Pt rod counter electrode and $\mathrm{Ag} / \mathrm{AgCl}$ saturated in $3 \mathrm{M} \mathrm{KCl}$ reference electrode. The films were illuminated with a $300 \mathrm{~W}$ Xenon lamp (PLSSXE300/300UV) was used for illumination which equipped a UV cut off filter $(\lambda>420 \mathrm{~nm})$. The luminous intensity of the Xenon lamp was about $150 \mathrm{~mW} / \mathrm{cm}^{2}$. The TEM analysis were characterized using a JEOL JEM 2100F operated at $300 \mathrm{kV}$ and equipped with an energy dispersive $\mathrm{X}$-ray spectrometer.

\subsubsection{Chemical bath deposition (CBD) process}

Chemical bath deposition (CBD) is based on the chemical precipitation of CdS which is discussed in chapter 2 in detail. Generally TEA were used as a complexing agent to control 
the free metal ions concentration, over all $\mathrm{pH}$ of the bath solution kept in between 9.5 and 10 adjusted by ammonia. We prepared four samples with different $\mathrm{Zn}$ concentration and annealing temperature.

\subsubsection{X-ray difractograms characterization}

The XRD patterns of as-deposited and annealed CdS thin films are shown in Figure 4.1. Several diffraction peaks located at the $25.10^{\circ}, 26.5^{\circ}, 37.5^{\circ}, 43.6^{\circ}, 45.3^{\circ}$, and $50.5^{\circ}$ and corresponding the lattice planes (100), (002), (102), (110), (103) and (004), respectively, are observed in these films. Annealing at $380^{\circ} \mathrm{C}$ results in higher intensities for XRD peaks what means that the film crystallinity improves with annealing. XRD patterns for the ternary $\mathrm{CdZnS}$ (with Zn contents 3\%,5\% and 10\%) are found to be located at the same $2 \theta$ angles because the $\mathrm{Zn}$ atoms locate at $\mathrm{Cd}$ sites.

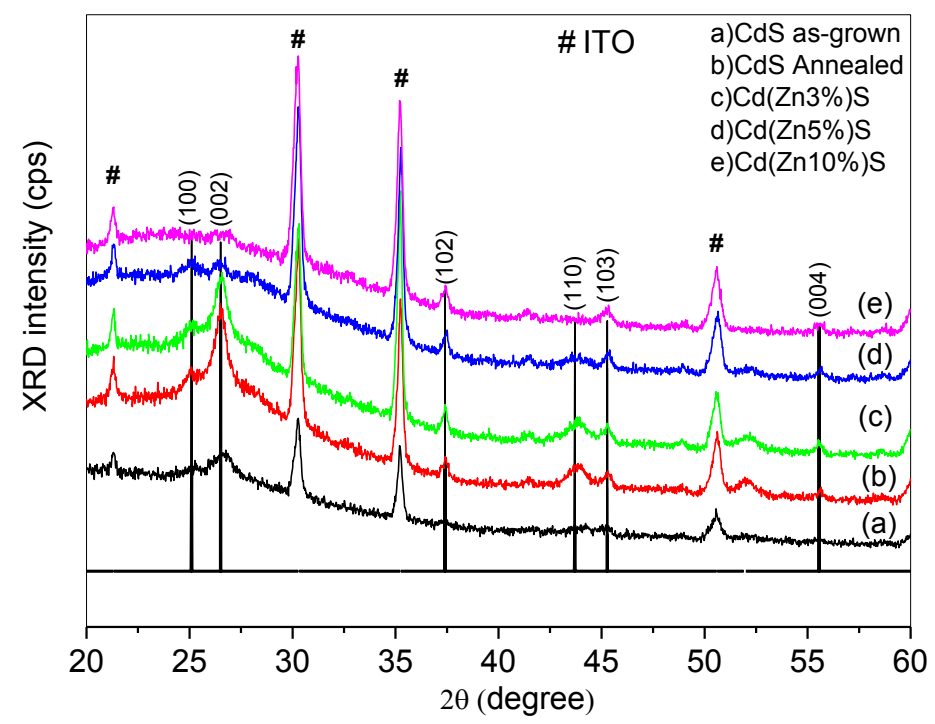

Figure 4.1. X-ray diffraction spectra of as-grown and annealed $\mathrm{CdS}$ and $\mathrm{CdZnS}$ thin films for different $\mathrm{Zn}$ content $3 \%, 5 \%$ and $10 \%$, respectively.

However, the intensity of diffraction peaks drops with increasing the $\mathrm{Zn}$ content, what is an indication that the poorer crystal quality of ternary CdZnS films [131]. Further, when the XRD pattern is analysed in detail a shift to lower angles is observed for the main diffraction peaks. When the $\mathrm{Zn}$ composition increases from $0 \%$ to $10 \%$ the position of the diffraction peaks slightly shifts to higher angles, suggesting that the $\mathrm{Cd}^{2+}$ ions $(109 \mathrm{pm})$ are been 
substituted by smaller in size $\mathrm{Zn}^{2+}$ ions $(88 \mathrm{pm})$ and then diffraction planes are closer and diffraction peaks shifts to higher angles. This fact is further verified by the blue shift observed by optical analysis.

\subsubsection{Scanning electron microscopy characterization}

Figure 4.2 shows the SEM images of the surfaces of different $\mathrm{CdZnS}$ thin films obtained from chemical baths with different $\mathrm{Zn}$ concentration. Figure 2 (a) corresponds to the as-deposited CdS thin film. Figure 4.2 (b), (c) and (d) correspond to CdZnS films with $\mathrm{Zn}$ contents of $3 \%, 5 \%$ and $10 \%$, respectively. The morphology of the films is quite homogeneous and consists of fine particles. The trend is that as $\mathrm{Zn}$ content increases both the grain size and crystallinity decrease.

Table 4.2 shows the elemental composition of $\mathrm{CdZnS}$ thin films investigated by EDS. The atomic amount of S seems to remain constant irrespective of the $\mathrm{Zn}$ content. However, as the $\mathrm{Zn}$ content is increased in the working solution the $\mathrm{Zn}$ content in the thin films proportionally increases while the $\mathrm{Cd}$ content decreases. The ratio between anions and cations [S] / $([\mathrm{Cd}]+[\mathrm{Zn}])$ remains quite constant regardless the $\mathrm{Zn}$ content in thin films. Therefore, all ternary $\mathrm{CdZnS}$ thin films are non-stoichiometric and exhibit a deficit of sulfur. 


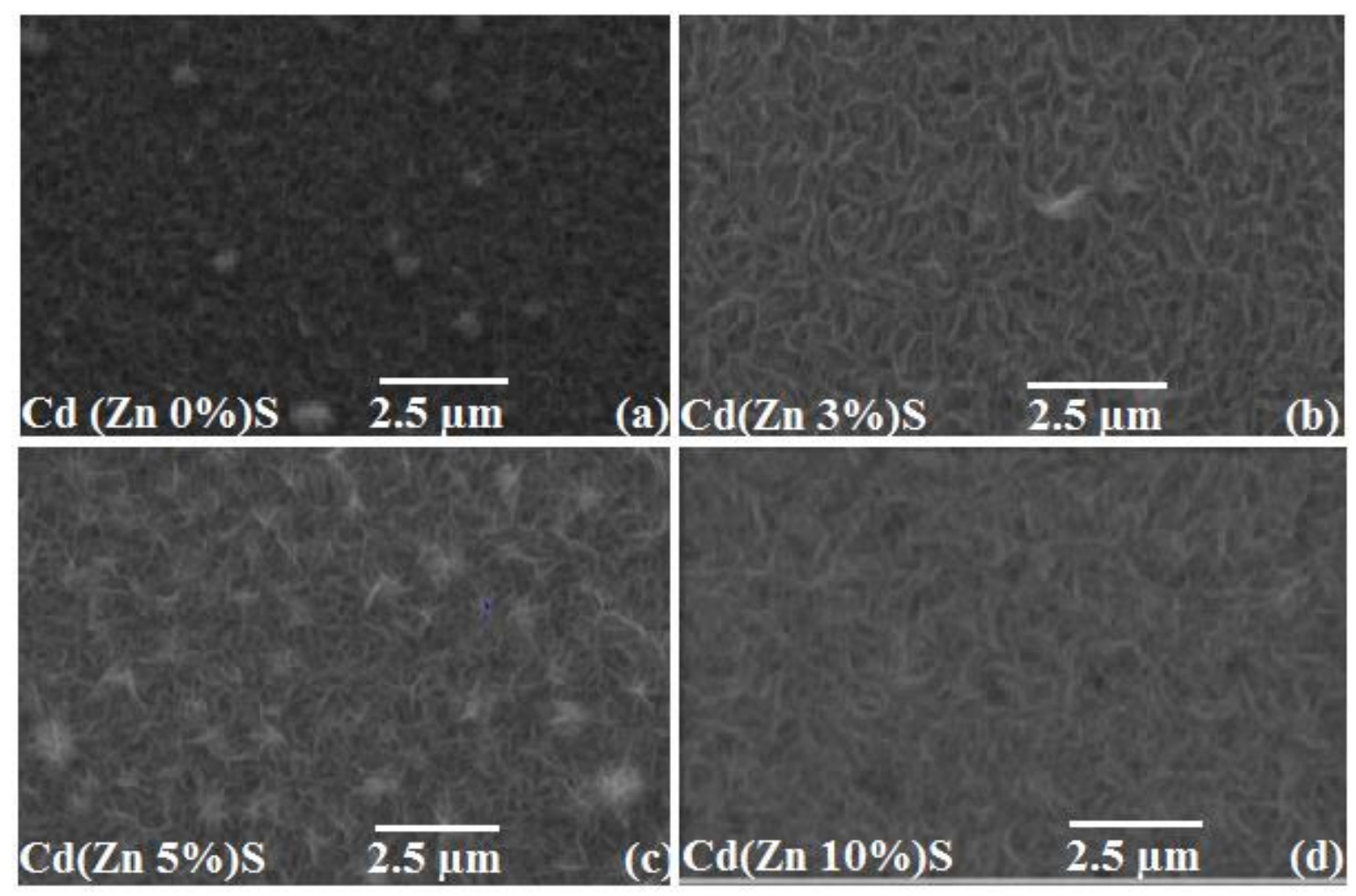

Figure 4.2. Top view SEM images of CdZnS thin films prepared with different amounts of Zn: (a) 0\%, (b) $3 \%$, (c) $5 \%$, and (d) $10 \%$.

\subsubsection{Atomic Force Microscopy characterization}

The surface morphology and the roughness of the $\mathrm{CdZnS}$ thin films analyzed by atomic force microscope is presented in Figure 4.3. It can be seen that the films changed the surface morphology to thin fine particles. According to atomic force microscopy, the roughness of the film decrease through $\mathrm{Zn}$ contents, for this reason the density of grain boundaries should be low to increase the transmission rate and improve the quality of the films and cell performance, which is favorable for solar cell applications as a window layer to increase blue photon transparency results in higher current.

Table 4.1 shows the characterization results performed by atomic force microscopy. A linear relationship between the grain size and roughness for all studied films was observed, when the roughness increases, the grain size also increases. The roughness at the CdS film is 98.1 $\mathrm{nm}$ and the grain size is $249.3 \mathrm{~nm}$. The observed difference in the surface morphologies of the films by adding the $\mathrm{Zn}$ content, the roughness of the films decreases from 98.1 to 23.5 $\mathrm{nm}$ and the grain size also decreases from 249.3 to $173.2 \mathrm{~nm}$. 

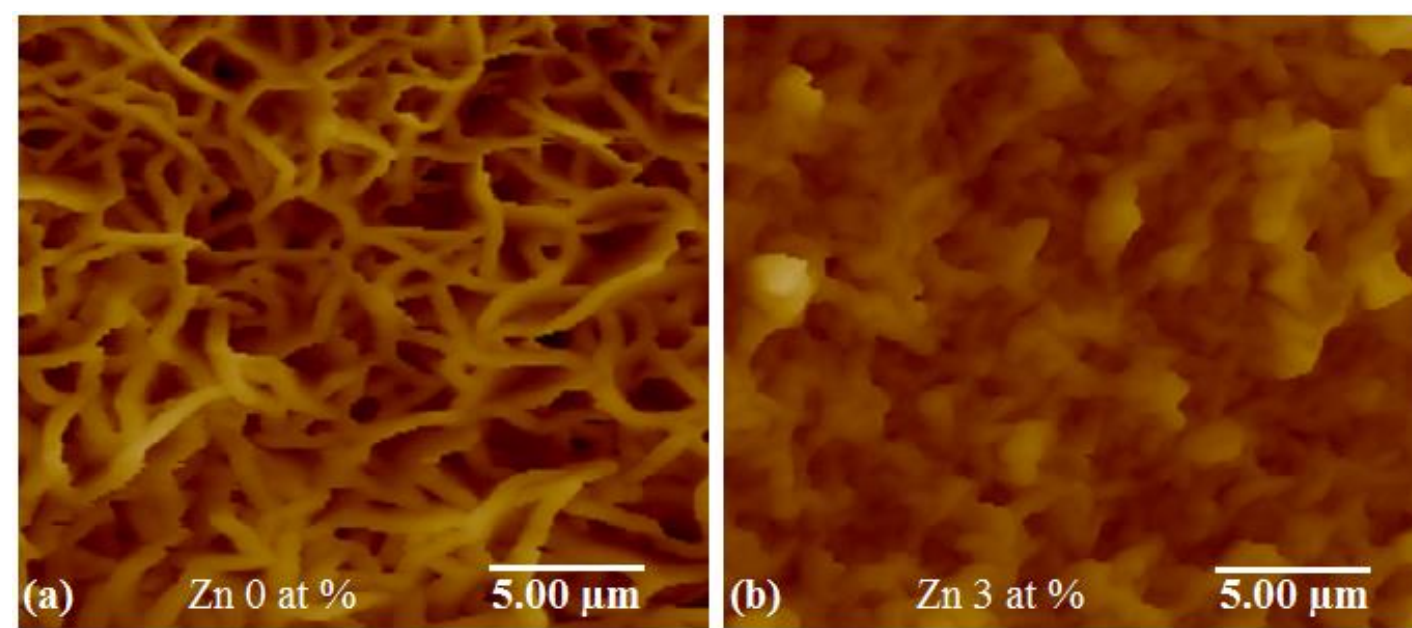

$700.0 \mathrm{~nm}$
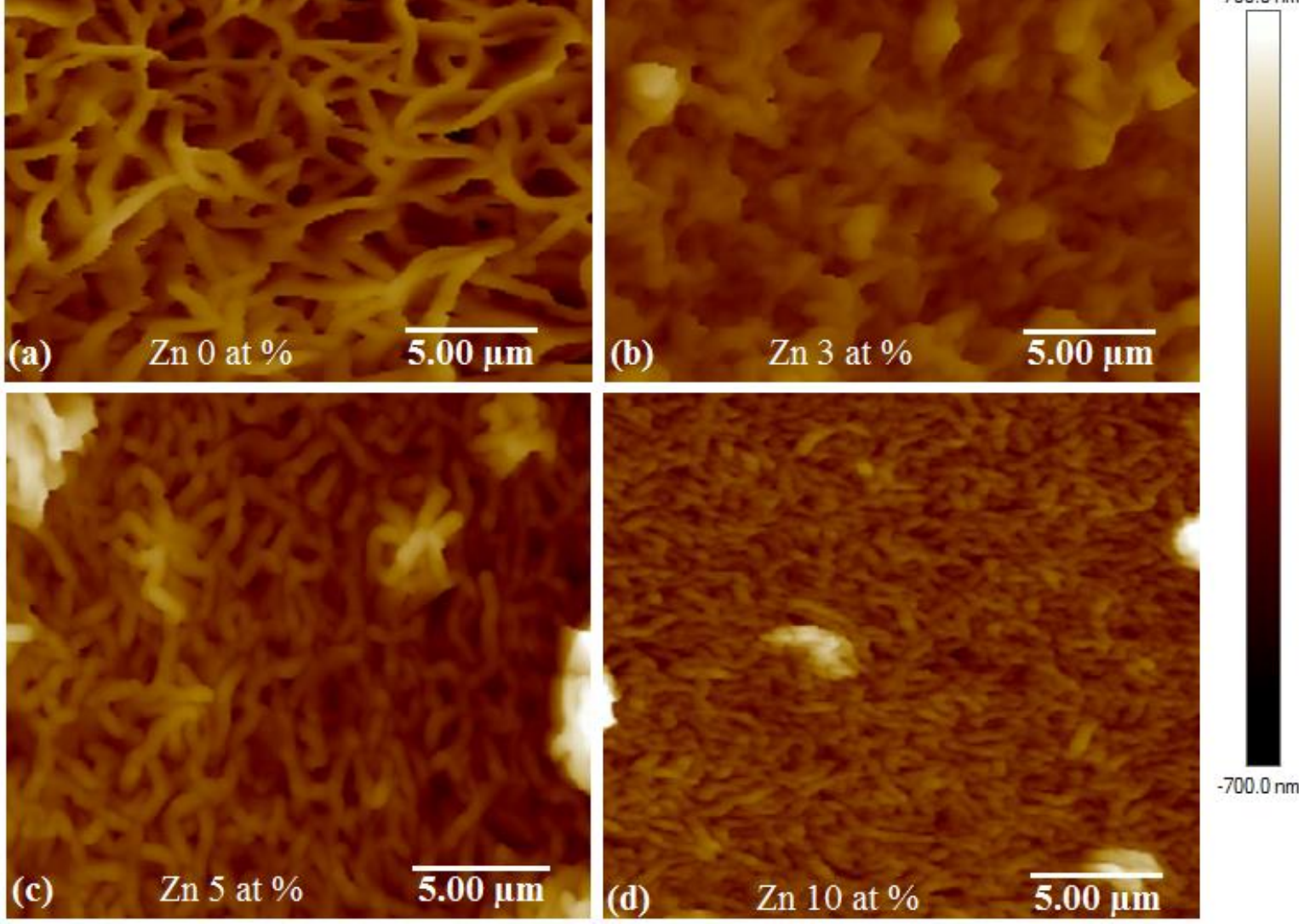

Figure 4.3. AFM micrograph of $\mathrm{CdZnS}$ with different amounts of $\mathrm{Zn}$ : (a) 0 at \%, (b) 3 at \%, (c) 5 at $\%$, and (d) 10 at $\%$ content.

\begin{tabular}{|c|c|c|c|}
\hline Sample id & Zn at \% & Roughness (nm) & Grain size (nm) \\
\hline $151202-001$ & 0 & 98.1 & 249.3 \\
\hline $151202-002$ & 3 & 76.2 & 219.2 \\
\hline $151202-003$ & 5 & 60.9 & 180.7 \\
\hline $151202-004$ & 10 & 23.5 & 173.2 \\
\hline
\end{tabular}

Table 4.1 Show the relation between roughness and grain size with different $\mathrm{Zn}$ contents.

\subsubsection{Transmission Electron Microscopy (TEM) Analysis}

To confirm the compositional grading in the $\mathrm{CdS}$ and $\mathrm{CdZnS}$ thin film, we performed surface morphology of the CdZnS thin film using transmission electron microscopy (TEM) 
and energy-dispersive X-ray spectroscopy (EDS) as shown in Figure 4.4 and 4.5 respectively. The HRTEM analysis reveals that both the $\mathrm{Cd}$ core and the $\mathrm{ZnCdS}$ sheath of the cable are well crystallized and the inter planer distance are $0.13 \mathrm{~nm}$ and $0.16 \mathrm{~nm}$ in (Figure. $4.4 \mathrm{~b}$, c and $4.5 \mathrm{~b}, \mathrm{c})$ respectively. The hexagonal structure of the $\mathrm{Cd}$ core and the $\mathrm{ZnCdS}$ sheath was also confirmed by HRTEM.

It was observed that the $\mathrm{Zn} /(\mathrm{Cd}+\mathrm{S})$ ratio increased drastically toward the surface of the $\mathrm{CdZnS}$ thin film, whereas the compositions of $\mathrm{Cd}, \mathrm{Zn}$ and $\mathrm{S}$ remained constant across the depth, as shown in Figure 4.6. TEM elemental mapping analysis was further examined the distribution of $\mathrm{Zn}$ in the doped samples. The elemental mappings of $\mathrm{Zn}, \mathrm{Cd}$, and $\mathrm{S}$, as shown in Figure 4.6, have a homogeneous spatial distribution. The concentration of $\mathrm{ZnCdS}$ were investigated by quantitative analyses of energy-dispersive X-ray spectroscopy (EDS). The EDS measurements are in good agreement with the nominal values, as summarized in (see Table 4.2).

Both samples exhibit a nearly spherical shape and uniform size one-and two-dimensional lattice structures are clearly observed. TEM measurement showed that the average size was $0.13 \pm 0.2 \mathrm{~nm}$ for $\mathrm{CdS}$ and $0.16 \pm 0.3 \mathrm{~nm}$ for $\mathrm{CdZnS}$ confirming a slight increase in CdS size with $\mathrm{Zn}$ content.
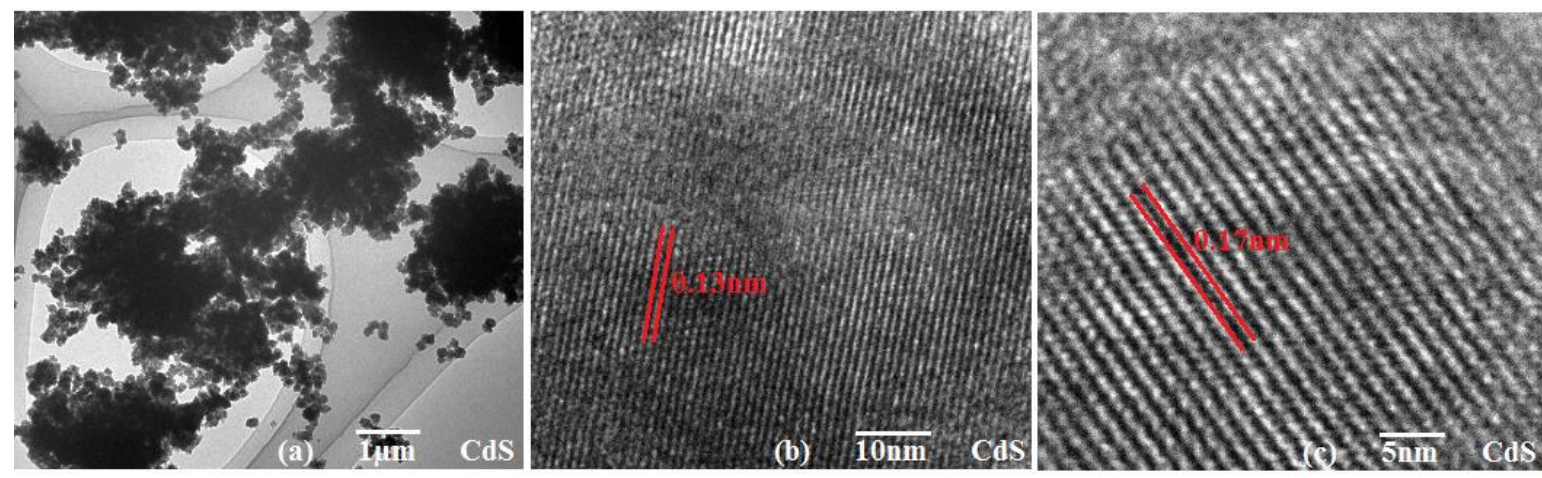

Figure 4.4 Top view TEM images of CdS thin films 

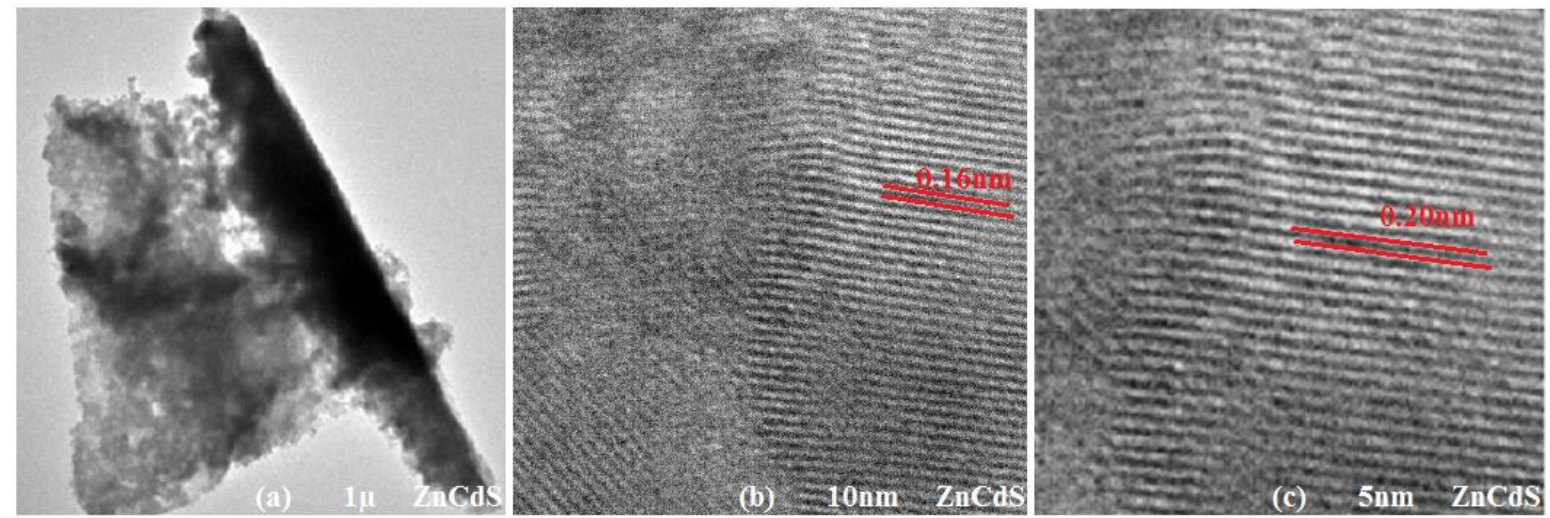

Figure. 4.5. (a) Top view TEM image of CdZnS thin films (b,c) HRTEM image of nano wire of ZnCdS with different nano scale.
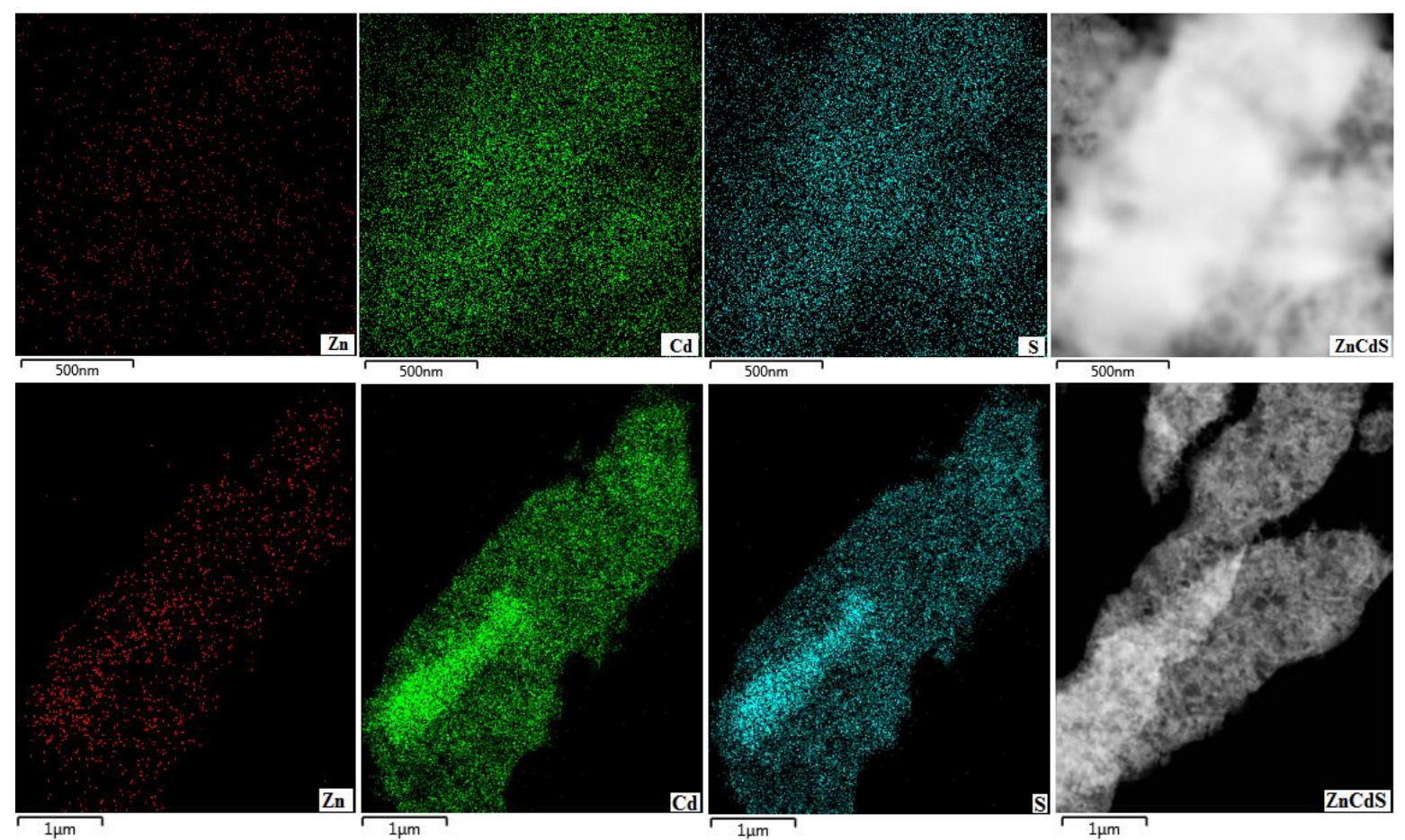

Figure 4.6. TEM images of $\mathrm{CdZnS}$ composite and elemental maps for each constituent element. 


\subsubsection{Optical characterization}

The optical properties such as absorption coefficient, transmittance and band gap energy of $\mathrm{CdZnS}$ thin films were determined in samples with different $\mathrm{Zn}$ contents. Figure 4.7 shows the optical transmittance versus the wavelength $(\lambda)$ in the range 300-1100 nm. An important shift to shorter wavelengths in the onset of the transmittance proportional to the $\mathrm{Zn}$ content is observed for $\mathrm{CdZnS}$ thin films. This is an indication of the increase of the optical band gap with the $\mathrm{Zn}$ content in ternary $\mathrm{CdZnS}$ thin films.

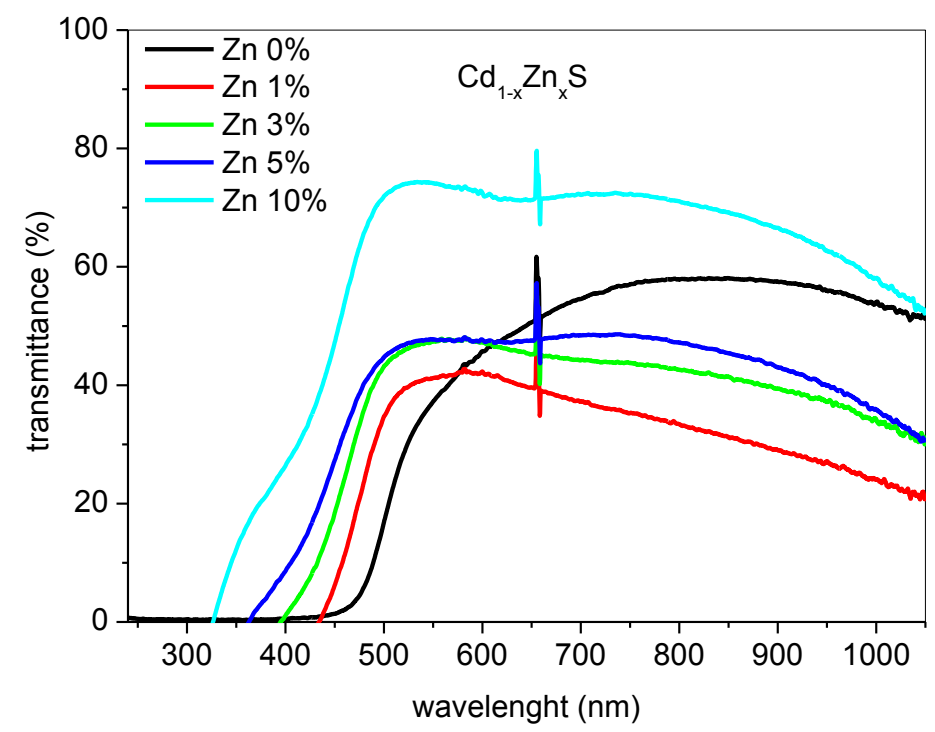

Figure 4.7. Optical transmittance for $\mathrm{CdZnS}$ with different $\mathrm{Zn}$ content.

Both CdS and CdZnS are considered direct band gap semiconductors. Then the optical band gap of direct band gap semiconductors can be estimated from by plotting the square of Absorbance times energy photon $(\mathrm{Ah} v)^{2}$ versus the photon energy $(\mathrm{h} v)$. Then the point where the extrapolation of the linear part of this curve cur the energy axis is the value of the optical band gap. Figure 4.8 shows the plot of $(\mathrm{Ahv})^{2}$ as a function of the photon energy for $\mathrm{CdZnS}$ thin films with different $\mathrm{Zn}$ amounts. 


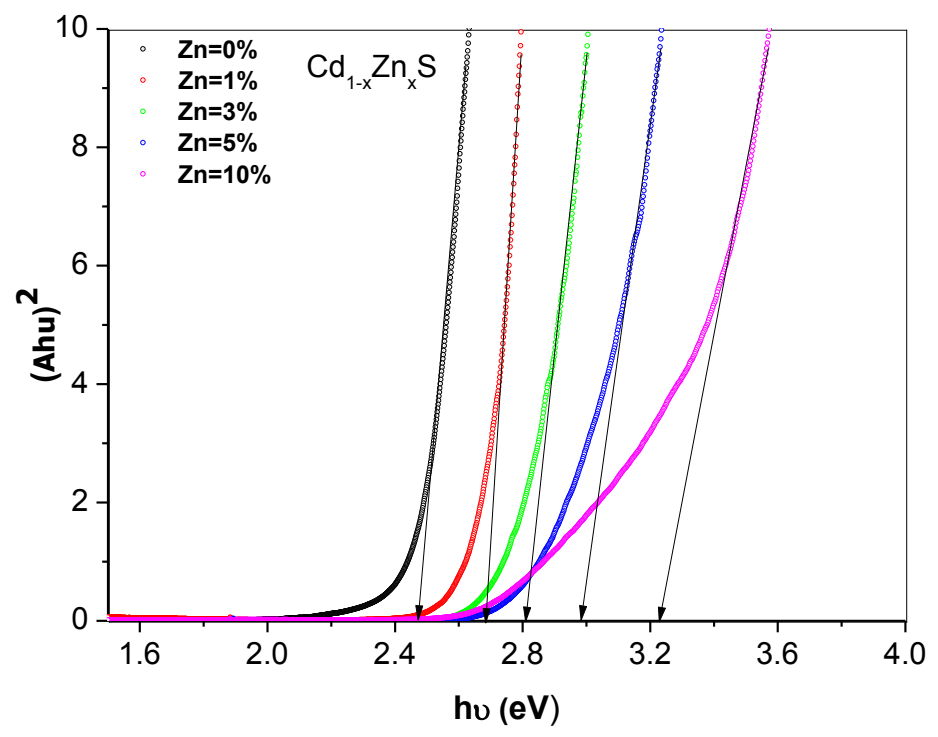

Figure 4.8. Plot of $(\mathrm{Ahv})^{2}$ versus the photon energy $(\mathrm{h} v)$ for $\mathrm{CdZnS}$ thin films with different $\mathrm{Zn}$ concentrations.

The observed results show that when increasing $\mathrm{Zn}$ content the band gap shifts to higher energies. The results for the optical band gap ranging from $2.43 \mathrm{eV}$ to $3.25 \mathrm{eV}$ for different CdZnS thin films appear in Table 4.2.

\begin{tabular}{|c|c|c|c|c|}
\hline Samples & Cd\% & S\% & Zn\% & Optical band gap (eV) \\
\hline Zn 0\% & 58.0 & 42.0 & 0.0 & 2.43 \\
\hline Zn 1\% & 57.6 & 41.4 & $<1$ & 2.68 \\
\hline Zn 3\% & 56.6 & 40.8 & 2.6 & 2.82 \\
\hline Zn 5\% & 54.6 & 40.6 & 4.8 & 3.00 \\
\hline Zn 10\% & 50.6 & 41.8 & 7.6 & 3.25 \\
\hline
\end{tabular}

Table 4.2. Elemental Composition obtained from EDS and optical band gap for CdZnS thin films with different $\mathrm{Zn}$ amounts. 


\subsubsection{Photo electrochemical analysis (PEC)}

Figure 4.9 shows the photoinduced current versus time (I-t) for $\mathrm{CdZnS}$ films with different $\mathrm{Zn}$ contents. The photocurrent intensity generated by the $\mathrm{ZnCdS}$ electrode was recorded at bias potential $0.1 \mathrm{~V}$ using a $0.1 \mathrm{M} \mathrm{KCl}$ electrolyte. These curves demonstrate the photoelectric conversion ability of the $\mathrm{CdZnS}$ ternary compounds. The photocurrent produced after the introduction of $\mathrm{Zn}$ was extremely high compare to the CdS. Comparing the I-t curves for $\mathrm{CdS}$ and $\mathrm{CdZnS}$ films, a small photo current intensity of $0.01 \mathrm{~mA}$ was obtained under light illumination for the CdS electrode and a significant promotion of the photocurrent intensity up to $0.06 \mathrm{~mA}$ was obtained when increasing the $\mathrm{Zn}$ content in the films. This further increase in the photocurrent intensity by 500\% was observed after the introduction of $\mathrm{Zn}$ doped with $\mathrm{CdS}$ electrode. The trend is the higher the $\mathrm{Zn}$ content in $\mathrm{CdZnS}$ thin films the higher the photoinduced current. The $\mathrm{Zn}$ doping increases donor concentration and enhances charge carriers transportation by increasing the electric field across the space charge layer. The increase of the donor concentration would reduce the width of the space charge layer; hence the charge carriers within the region are efficiently separated before recombination.

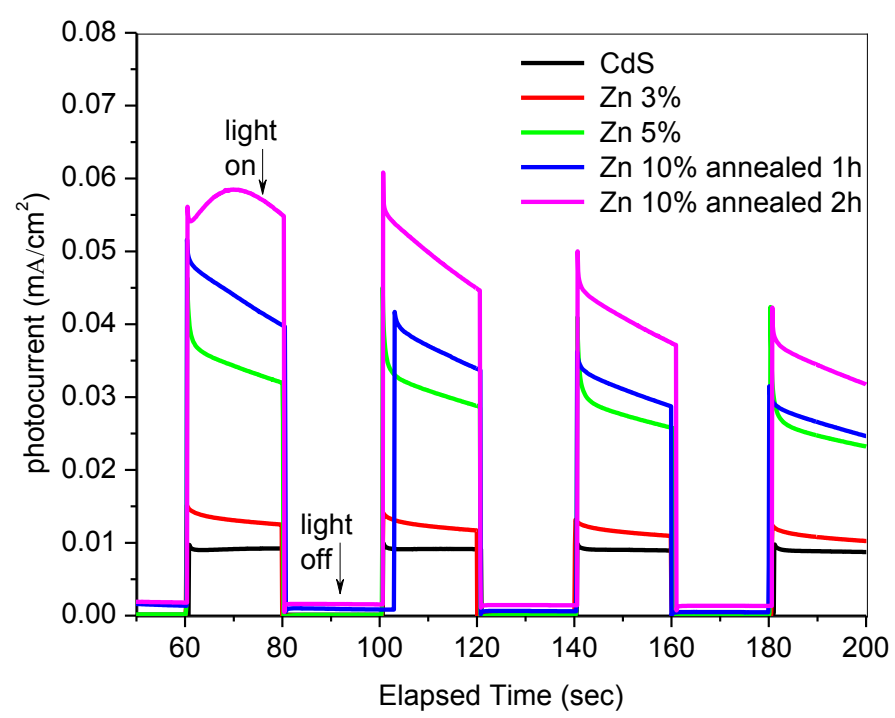

Figure 4.9. Time-based photocurrent intensities of $\mathrm{CdZnS}$ electrodes measured in $0.1 \mathrm{M} \mathrm{KCL}$ electrolyte under a potential of $+0.1 \mathrm{~V}$ in the dark and under illumination. 


\section{Conclusion}

$\mathrm{CdZnS}$ thin films with different Zn contents have been deposited on ITO substrate by Chemical Bath Deposition. XRD patterns confirm that the CdZnS films have polycrystalline structure and exhibit the same hexagonal structure of CdS films. FESEM images of CdZnS thin films show uniform distribution of homogeneous fine particles. The density of grain boundaries seems to decrease with the increase of $\mathrm{Zn}$ content. The grain sizes observed by AFM of the CdZnS thin films vary between 173.2 and $249.3 \mathrm{~nm}$. The average surface roughness of the CdZnS thin films have been determined to vary between 23.5 and $98.1 \mathrm{~nm}$. The optical properties, such as transmittance and the energy band gap structure of $\mathrm{CdS}$, are strongly affected by increasing Zn content, which is the cause of the blue shift observed in the optical band gap from $\approx 2.42$ to $3.25 \mathrm{eV}$ as the $\mathrm{Zn}^{2+}$ compositional parameter increased in the chemical bath. In the photo electrochemical analysis, a significant promotion in photocurrent intensity was observed for different Zn concentration. PEC study suggests that the incorporated of $\mathrm{Zn}$ increases the conductivity of $\mathrm{CdS}$ which enhances the photocurrent generation.

This work demonstrates that good quality $\mathrm{CdZnS}$ thin films can be efficiently deposited by CBD. These ternary CdZnS thin films are suitable to be used as buffer or window layers in optoelectronic devices such as CIGS and CdTe solar cells due to their higher transparency and better surface morphology. 
This page intentionally left blank 


\section{Chapter 5}

\section{$\mathrm{CuGaS}_{2}$ : $\mathrm{Cr}$ simulation work}

\subsection{Introduction}

CIGS Chalcopyrite semiconductors are one of the promising materials to be used in high-performance photovoltaic devices due to their direct bandgap, which can be tuned between 1.1 for $\mathrm{CuInSe}_{2}$ and $2.2 \mathrm{eV}$ for $\mathrm{CuGaS}_{2}$. Also, their cost-effectiveness and easy processing are well known. Recently, CIGS thin-film photovoltaic devices reached a record solar efficiency of 22.3\% [132]. Among thin film technologies, CIGS solar cells have achieved highest conversion efficiencies at laboratory scale [133,134]. Efforts to seek an economical and scalable method for the production of stoichiometric CIGS thin-films have been going on to allow the commercialization of these devices. Among several techniques, electrodeposition has demonstrated to produce CIGS devices with high efficiency [135]. Currently efforts are being made to increase the thin film efficiency to the theoretical determination as well as to improve inexpensive deposition strategies for the chalcopyrite absorber layer [136].

The band gap energy of semiconductor materials plays a key role in performance of photovoltaic devices [137]. According to the Shockley-Queisser limit the optimal band gap energy of single band gap PV device was calculated to be about $1.4 \mathrm{eV}$ [138]. Therefore, it would be unreasonable to use $\mathrm{CuGaS}_{2}$ thin film as absorber in photovoltaic devices based on one junction due to their high band gap which is about $2.2 \mathrm{eV}$. However, this energy matches the optimal bandgap well to host an in-gap band (IGB) (also known as intermediate band) intended to absorb photons with energies lower than the gap. In the proposed IGB material electrons can follow two ways to be promoted from the valence band to the conduction band: a) absorbing a photon with energy higher than the bandgap, and b) through the absorption of two photons with energy below the bandgap. The absorption of one photon promotes one electron from the valence band to the partially filled IGB and then the electron is transferred from this IGB to the conduction band after the absorption of a second photon. This may allow a more efficient use of the solar spectrum in photovoltaic devices. This type of solar cells would be able to utilize the solar spectrum more efficiently, resulting in a theoretical efficiency limit of $63.2 \%$ [139], which is significantly higher than the $40.7 \%$ limit of 
conventional single band-gap photovoltaic cells [7]. Such devices would possess higher open circuit voltages and increased short circuit currents due to the higher band gap energy of the absorbing material and the greater absorption coming from sub-band gap photons, resulting in an increase of the overall efficiency [140].

According to the literature [141], chrome substituting $\mathrm{Ga}$ in $\mathrm{CuGaS}_{2}$ chalcopyrite lattices would generate an IGB separated from both valence and conduction bands. When the transition metal $(\mathrm{Cr})$ IGB is introduced into the $\mathrm{CuGaS}_{2}$ lattice it produces a partially filled band separated from both conduction and valence bands that allows promoting electron-hole pairs through a two photon absorption process with sub bandgap energies. Therefore, the use of an IGB absorber would allow harvesting higher amounts of solar photons.

The main determination of the present work is to dope $\mathrm{CuGaS}_{2}$ thin films with the transitionmetal $\mathrm{Cr}$ to create a suitable IGB absorber [142]. Herein, we report the synthesis and optical characterization of $\mathrm{CuGaS}_{2}$ and $\mathrm{CuGaS}_{2}: \mathrm{Cr}$ thin films containing an IGB associated to $\mathrm{Cr}$. $\mathrm{CuGaS}_{2}$ thin films were produced by sulfurization of previously electrodeposited $\mathrm{CuGaSe}_{2}$ films. The replacement of Se by S was completely substituted after sulfurization. Optical analysis showed that the band gap shifted from 1.66 for $\mathrm{CuGaSe}_{2}$ to $2.20 \mathrm{eV}$ for $\mathrm{CuGaS}_{2}$. with the sulfurization, the position of X-Ray diffractograms peaks also shifted from 27 to 29 degrees. The effectiveness of $\mathrm{Cr}$-doping was inferred from the presence of $\mathrm{Cr}$ in $\mathrm{CuGaS}_{2}$ layers detected by microanalysis and the optical detection of an in-gap absorption band. Furthermore, the behaviour of photovoltaic devices, based on $\mathrm{CuGaS}_{2}$ absorbers with and without an IGB, was calculated specific Solar Cell Capacitance Simulation (SCAPS) software [143].

\subsection{Preparation of $\mathrm{CuGaSe}_{2}, \mathrm{CuGaS}_{2}$ thin films}

$\mathrm{CuGaSe}_{2}$ layers were electrodeposited from an electrolyte solution containing $2 \mathrm{~m}$ $\mathrm{Mol} \mathrm{L}{ }^{-1} \mathrm{CuCl}_{2}, 4 \mathrm{mmol} \mathrm{L}^{-1} \mathrm{H}_{2} \mathrm{SeO}_{3}, 10 \mathrm{mmol} \mathrm{L}^{-1} \mathrm{GaCl}_{3}, 50 \mathrm{mmol} \mathrm{L}^{-1} \mathrm{KSCN}, 100 \mathrm{mmol} \mathrm{L}{ }^{-1}$ $\mathrm{NH}_{4} \mathrm{Cl}$ and $300 \mathrm{mmol} \mathrm{L}^{-1} \mathrm{LiCl}$. The precursor solution $\mathrm{pH}$ was adjusted between 2.3 and 2.4 by adding hydrochloric acid $(\mathrm{HCl})$ and potassium hydroxide $(\mathrm{KOH})$. For better stability of the deposition bath solution $\mathrm{LiCl}$ was used as a supporting electrolyte, also improving the quality of the deposited layers. 
Electrodeposition was performed on a standard 3-electrode electrochemical cell. The $\mathrm{CuGaSe}_{2}$ thin films were deposited onto a $1 \mu \mathrm{m}$ thick Mo-coated soda lime glass substrate acting as a working electrode, a platinum wire was used as counter electrode and $\mathrm{Ag} / \mathrm{AgCl}$ as reference electrode.

For doping purposes, $\mathrm{Cr}^{3+}$ ions were added to the electrolyte described above. $150 \mathrm{mMol} \mathrm{L}-$ ${ }^{1}$ of $\mathrm{Cr}\left(\mathrm{ClO}_{4}\right)_{3}$ was dissolved in $40 \mathrm{~mL}$ of the electrolyte aqueous solution. The $\mathrm{pH}$ of the final solution was adjusted between 2.3 and 2.4 using concentrated $\mathrm{HCl}$. Electrodeposition produced $\mathrm{Cr}$-doped $\mathrm{CuGaSe}_{2}$ films and these films, which were subsequently sulfurized following the sulfurization procedure described below.

$\mathrm{CuGaS}_{2}$ layers were obtained after subsequent sulfurization of previously electrodeposited $\mathrm{CuGaSe}_{2}$ layers. A complete replacement of the selenium by sulfur, transforming the precursor $\mathrm{CuGaSe}_{2}$ wurtzite film into a $\mathrm{CuGaS}_{2}$ chalcopyrite film took place in a quartz tube kept inside a cylindrical oven at a temperature of $400{ }^{\circ} \mathrm{C}$ for 10 minutes in forming gas atmosphere.

The crystal structure of $\mathrm{CuGaSe}_{2}$ and $\mathrm{CuGaS}_{2}$ thin films were investigated by X-Ray Diffraction (XRD) with a Rigaku Ultima IV diffractometer in the Bragg-Brentano configuration using $\mathrm{CuK} \alpha$ radiation $(\lambda=1.54060 \AA)$. The chemical composition was analysed by means of Energy Dispersive Spectroscopy (EDS) with a FESEM Zeiss model Ultra55.

\subsubsection{X-ray difractogram characterization}

Figure 5.1 shows the XRD patterns of $\mathrm{CuGaSe}_{2}$ and $\mathrm{CuGaS}_{2}$ thin films at their different preparation stages: (a) electrodeposited $\mathrm{CuGaSe}_{2}$ thin films and (b) sulfurized $\mathrm{CuGaSe}_{2}$ thin films annealed for 10 minutes at $450{ }^{\circ} \mathrm{C}$. The diffractogram obtained for $\mathrm{CuGaSe}_{2}$ thin films matches the tetragonal crystal system JCPDS No. 075-0104 pattern well. The major peaks were located at $27.9^{\circ}, 45.7^{\circ} / 46.2^{\circ}$ and $54.3^{\circ} / 55.2^{\circ}$ corresponding to $\left(\begin{array}{lll}1 & 1 & 2\end{array}\right)$,

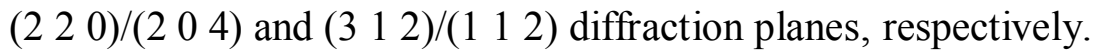



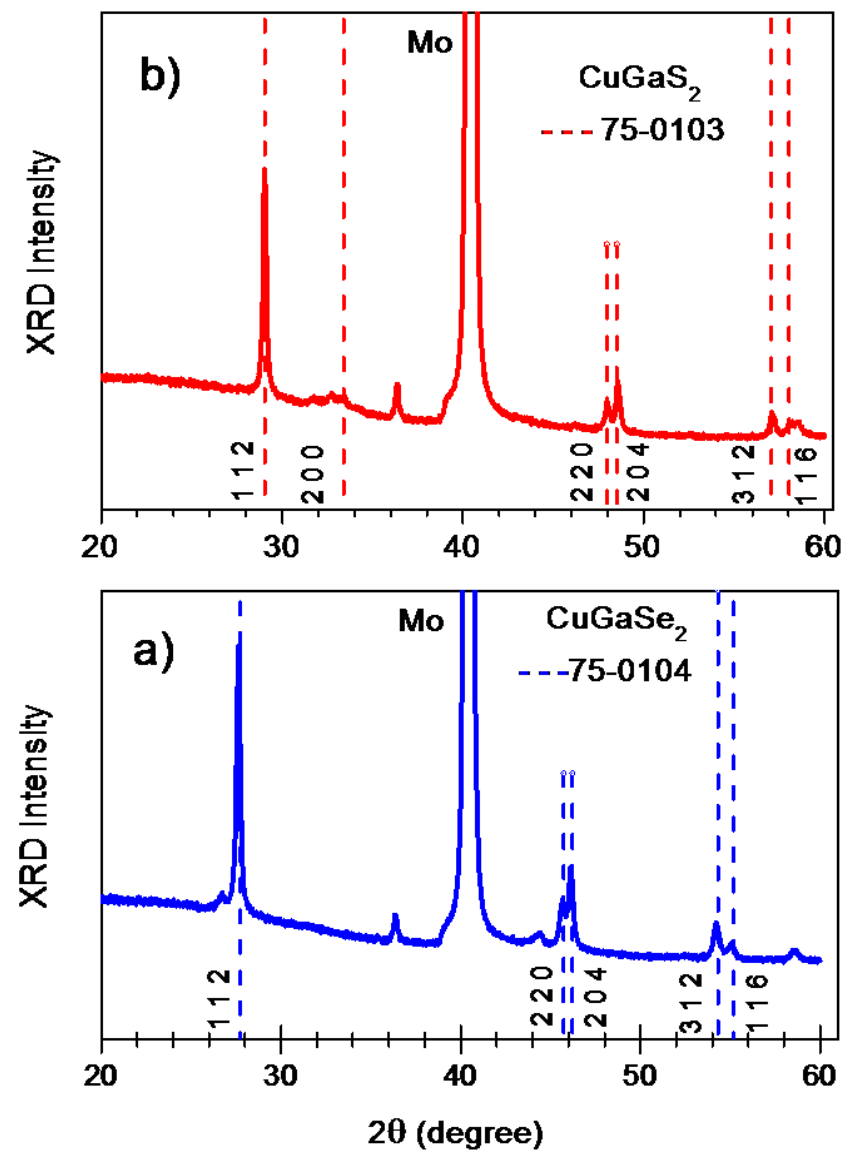

Figure 5.1. $\mathrm{XRD}$ patterns of $\mathrm{CuGaSe}_{2}$ and $\mathrm{CuGaS}_{2}$ films: (a) $\mathrm{CuGaSe}_{2}$ after annealing at $400{ }^{\circ} \mathrm{C}$ in forming gas atmosphere, and (b) after sulfurization in molecular sulfur for 10 minutes at $400{ }^{\circ} \mathrm{C}$.

The sulfurization process of the electrodeposited $\mathrm{CuGaSe}_{2}$ films took place after a short annealing time in presence of molecular sulfur, resulting in the formation of the $\mathrm{CuGaS}_{2}$ chalcopyrite phase as revealed by the XRD pattern of sulfurized films, [Figure 1 (b)]. The XRD peaks shifted to higher angles with the sulfurization process. The main XRD peak corresponding to (lllll 112 ) diffraction peaks shifted from 27.9 to 29.0 degrees. Furthermore,

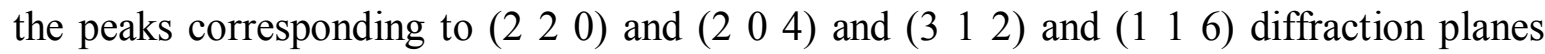
observed for annealed $\mathrm{CuGaSe}_{2}$ films also shifted to higher angles for sulfurized films. These XRD peaks match the JCPDS No. 75-0103 pattern corresponding to $\mathrm{CuGaS}_{2}$ films. This diffraction pattern confirms the replacement of Se atoms by $\mathrm{S}$ atoms after sulfurization, and consequently, $\mathrm{CuGaSe}_{2}$ thin films were transformed into $\mathrm{CuGaS}_{2}[144,145,146]$. 
Both $\mathrm{CuGaSe}_{2}$ and $\mathrm{CuGaS}_{2}$ films exhibited a tetragonal crystalline structure. The XRD patterns of $\mathrm{CuGaSe}_{2}$ and $\mathrm{CuGaS}_{2}$ thin films display a highly crystalline structure, offering the possibility of being used for photovoltaic devices with high conversion efficiency [147].

\subsubsection{Energy dispersive spectroscopy characterization}

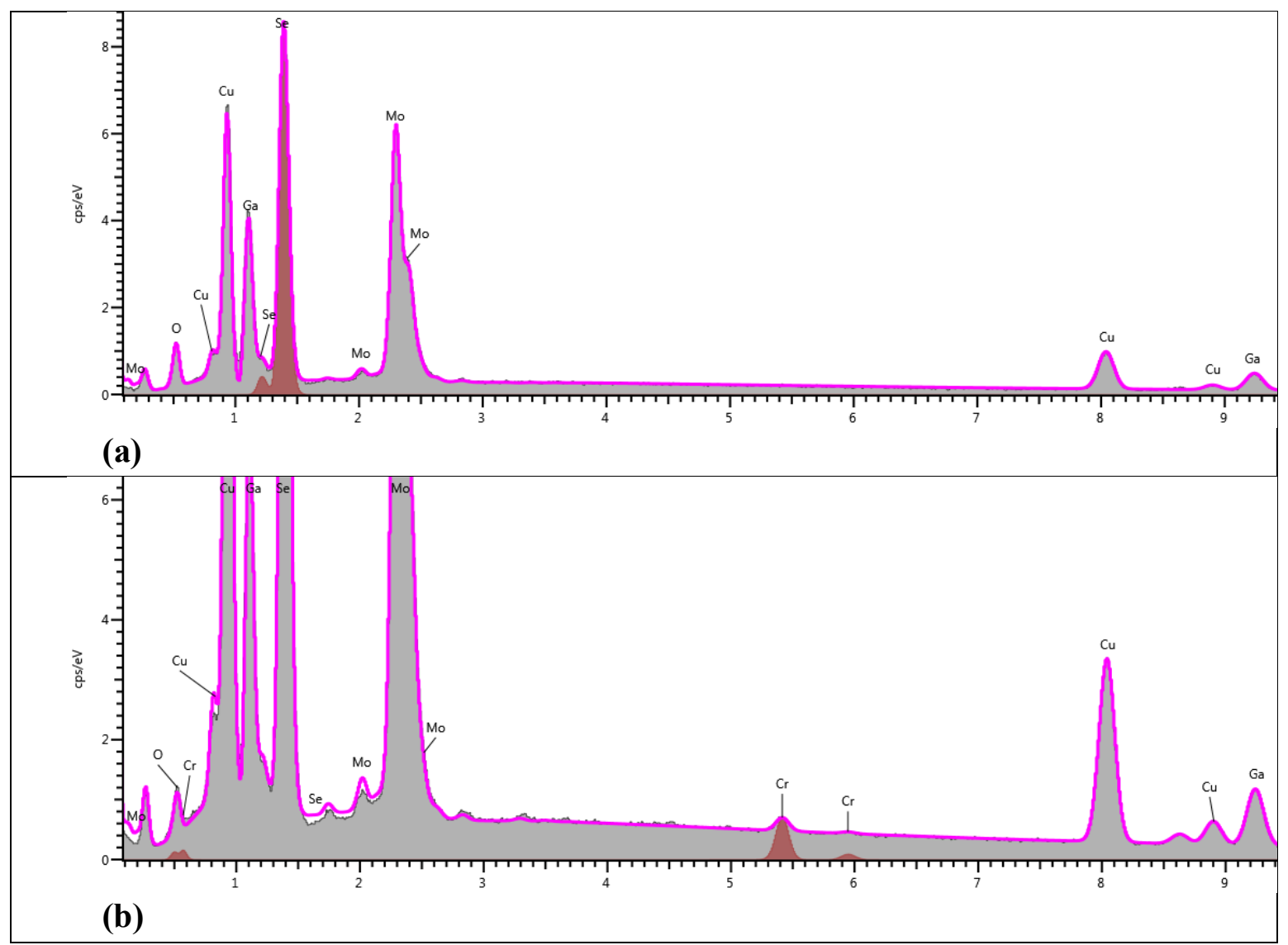

Figure 5.2. EDS spectrum for: a) annealed $\mathrm{CuGaSe}_{2}$, b) $\mathrm{CuGaSe}_{2}$ doped with $\mathrm{Cr}$.

EDS was used to estimate the composition of deposited $\mathrm{CuGaSe}_{2}$ and $\mathrm{CuGaS}_{2}$ films. Figure 5.2 (a, b) shows the EDS spectra of annealed $\mathrm{CuGaSe}_{2}$ and $\mathrm{CuGaSe}_{2}$ films doped with chrome. Main X-ray peaks belong to $\mathrm{Cu}, \mathrm{Ga}, \mathrm{Se}$ and Mo, produced by the substrate. $\mathrm{In} \mathrm{Cr}$ doped $\mathrm{CuGaSe}_{2}$ films, three lines located at $0.5,5.5$ and $6.0 \mathrm{keV}$, respectively, support the presence of chrome in these samples. After sulfurization the lines related to Se practically disappear, which means that the substitution of selenium by sulfur took place [148]. Only a residual part of selenium (below 1\%) remains after 10-minute sulfurization. The content of 
chrome in doped films always remains between 1 and $2 \%$, irrespective of the amount of $\mathrm{Cr}^{3+}$ added to the starting electrolyte, which means that the $\mathrm{Cr}$ :Ga ratio ranges from 4 to $8 \%$.

\subsubsection{Optical analysis of the $\mathrm{CuGaSe}_{2}, \mathrm{CuGaS}_{2}$ and $\mathrm{CuGaS}_{2}: \mathrm{Cr}$ thin films}

Figure 5.3 shows the normalized absorbance for $\mathrm{CuGaSe}_{2}, \mathrm{CuGaS}_{2}$ and $\mathrm{CuGaS}_{2}: \mathrm{Cr}$ thin films, respectively. According to Figure 5.3 (a), the cut-off wavelength for $\mathrm{CuGaSe}_{2}$ is about $746 \mathrm{~nm}$, which corresponds to a bandgap of $1.6 \mathrm{eV}$. Figure 5.3 (b) displays the

normalized absorbance for $\mathrm{CuGaS}_{2}$ films after sulfurization treatment. The cut-off wavelength for $\mathrm{CuGaS}_{2}$ films shifts to a lower wavelength $(563 \mathrm{~nm})$, which means a higher energy bandgap (2.2 eV). Figure 5.3 (c) shows the normalized absorbance for $\mathrm{CuGaS}_{2}: \mathrm{Cr}$ thin films. An additional characteristic with respect to undoped $\mathrm{CuGaS}_{2}$ films is evidenced: in $\mathrm{CuGaS}_{2}$ :Cr films, a wide absorption band centered at $760 \mathrm{~nm}(1.63 \mathrm{eV})$ appears. This absorption band can be assigned to a sub-band related to $\mathrm{Cr}$-doping. According to theoretical studies, the substitution $\mathrm{Ga}^{3+}$ by some transition metals like $\mathrm{Cr}$ would give rise to a partially filled absorption band into $\mathrm{CuGaS}_{2}$ chalcopyrite structures, which would then support the promotion of electrons from the valence band to the conduction band through a two-photon absorption procedure [149]. 


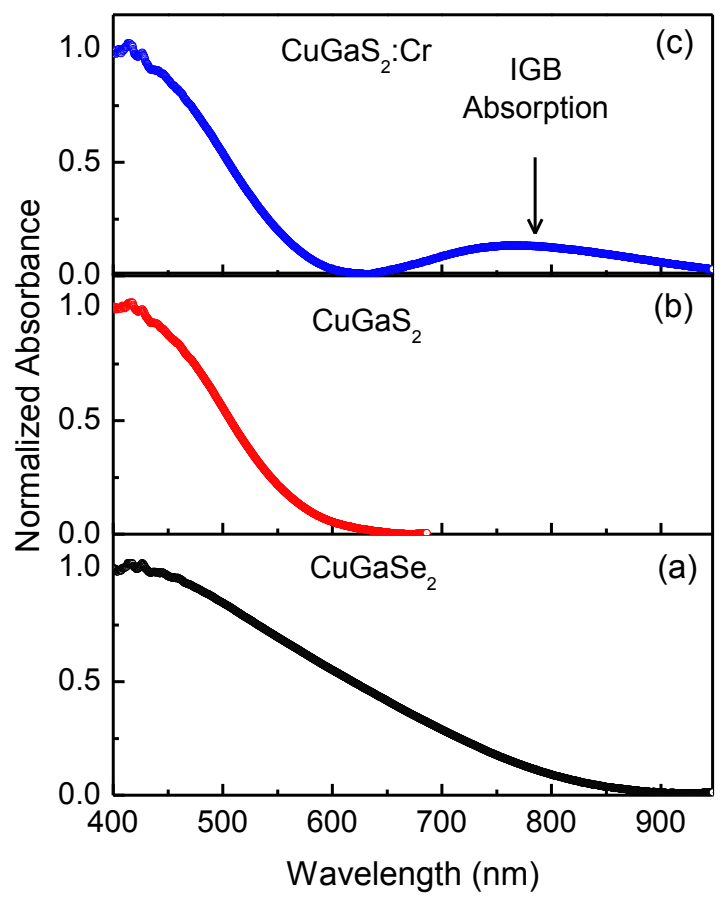

Figure 5.3. Comparison of the absorbance of $\mathrm{CuGaSe}_{2}, \mathrm{CuGaS}_{2}$ and $\mathrm{CuGaS}_{2}: \mathrm{Cr}$ thin films. The broad absorption band observed for $\mathrm{CuGaS}_{2}: \mathrm{Cr}$, centred at $760 \mathrm{~nm}$, is attributed to the Cr-related in-gap band.

The proposed in-gap band concept has gained a great deal of attention in the field of third generation solar cell research. The IGB position should neither overlap with the valence band (VB) nor with the conduction band (CB). Such an in-gap band does not only absorb photons having an energy higher than that of the band gap (Eg) but also permits the absorption of photons corresponding to the sub-band gap, which are capable to promote electrons from the VB to the IGB and then from the IGB to the CB [150]. The IGB associated to Cr-doped $\mathrm{CuGaS}_{2}$ may allow a higher current to be obtained at the voltage corresponding to the energy gap value, which is described in detail in the simulation part.

\subsection{Intermediate band concept and model}

The intermediate band concept is based on an adjustment of the electronic structure of a semiconductor, by introducing a partially filled intermediate band with in the band gap $[151,152]$ presented in figure 5.4. This divides the band gap into smaller energy units, subband gaps. The intermediate band acts as a stepping stone [153] for low-energy photons. The 
semi-filled intermediate band will function as an electron receiver as well as an electron supplier. The electronic structure of an IBSC will in other words allow absorption of three photon at the same time. The absorption spectrum of an intermediate band solar cell illustrated in figure 5.5 which cover large range of the solar spectrum will thus be utilized compared to conventional solar cells. The multi-absorption creates more free electron and hole pairs available for increasing the electric current without lowering the voltage of the cell [154]. As a result the efficiency of the cell rises due to the enlarged energy output per unit of incoming radiation.

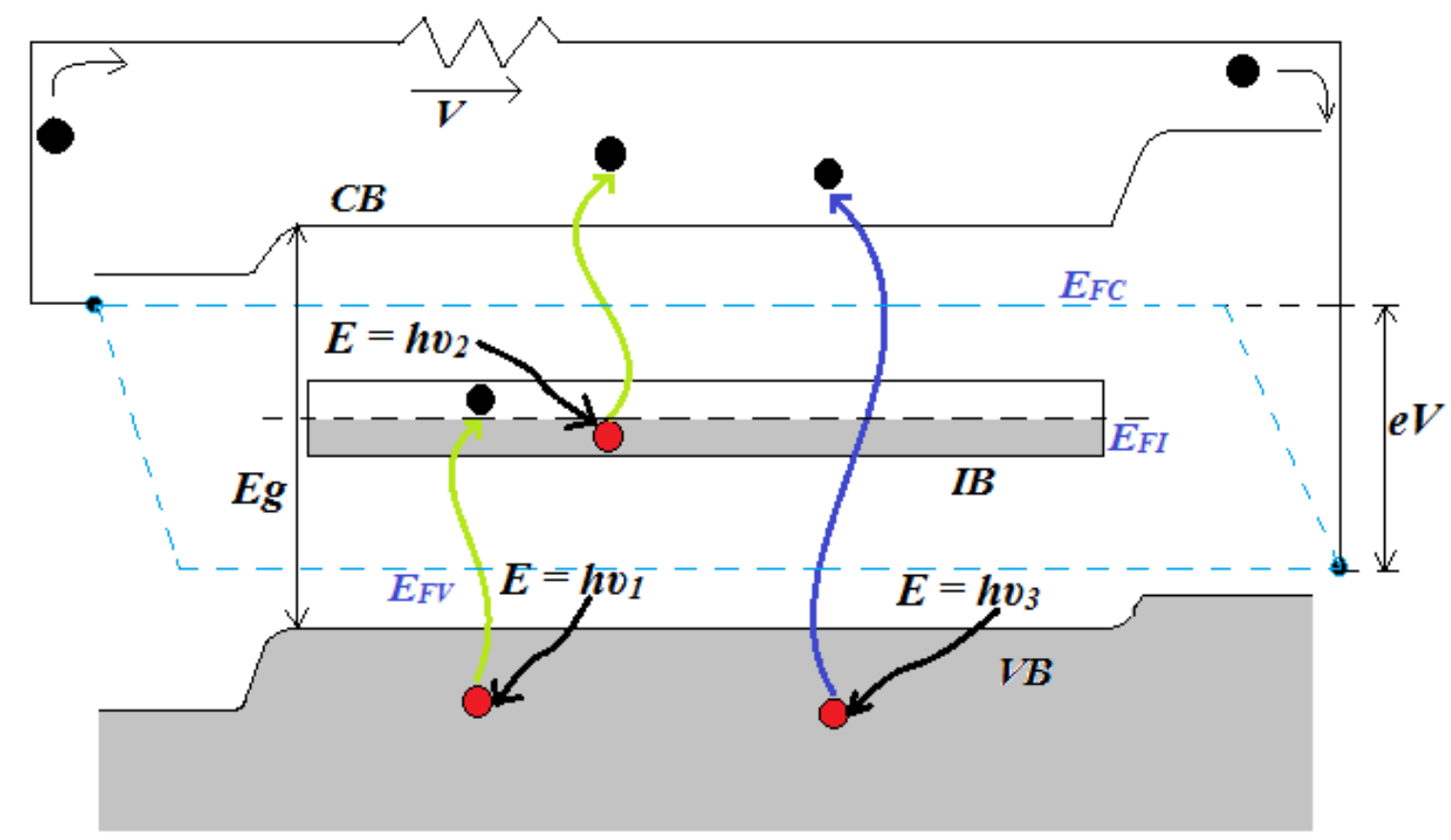

Figure 5.4: The electronic structure and design of an intermediate band solar cell. 


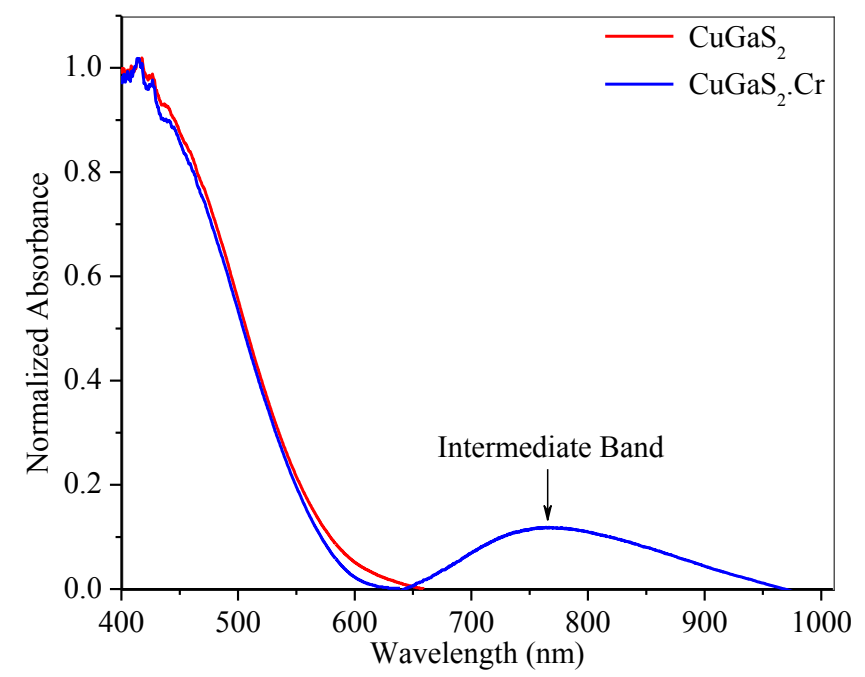

Figure 5.5. Illustration of the absorbance spectrum of an intermediate band solar cell.

\subsection{Numerical simulation of solar cells based on $\mathrm{CuGaS}_{2}$ : $\mathrm{Cr}$ absorbers.}

The performance of photovoltaic devices based on IGB-absorbers has been numerically simulated using SCAPS. The simulated photovoltaic device consists of the following sequence of layers: $\mathrm{Mo} / \mathrm{CuGaS}_{2}: \mathrm{Cr} / \mathrm{CdS} / \mathrm{ZnO}$ corresponding to back contact, absorber, buffer and window layers, respectively.

In the simulation we used the experimental absorption coefficient measured for $\mathrm{CuGaS}_{2}: \mathrm{Cr}$ considering that $5 \%$ of Ga was substituted by $\mathrm{Cr}$. To further estimate the effectiveness of the Cr-related IGB, we proportionally increased the Cr content to $10 \%$ and $20 \%$ and then studied its effect on the performance of the solar cell. 


\subsubsection{Energy band diagram of $\mathrm{Mo} / \mathrm{CuGaS}_{2} / \mathrm{CdS} / \mathrm{ZnO}$ thin films solar cell}

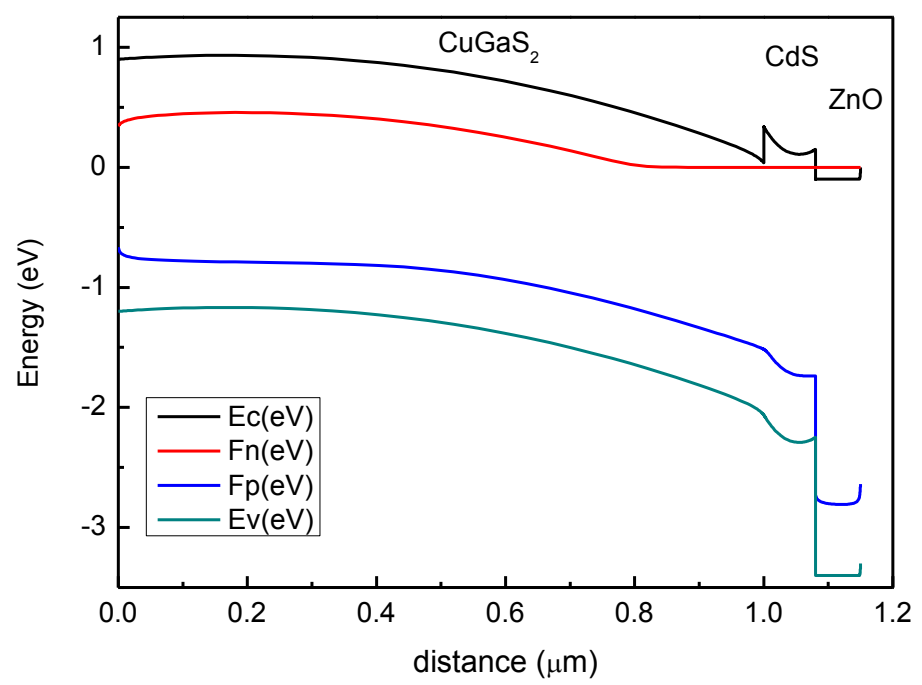

Figure 5.6. Band diagram of the $\mathrm{Mo} / \mathrm{CuGaS}_{2} / \mathrm{CdS} / \mathrm{ZnO}$ thin film solar cell.

Figure 5.6 shows the energy band diagram for $\mathrm{Mo} / \mathrm{CuGaS}_{2}: \mathrm{Cr} / \mathrm{CdS} / \mathrm{ZnO}$ thin film solar cells. The diagram plots various key electron energy levels as the Fermi level and the energy band edges. The band gap of pure $\mathrm{CuGaS}_{2}$ is $2.2 \mathrm{eV}$, which is appropriate for hosting an IGB separated from both conduction and valence bands. Cr doping originates an IGB centered at $1.63 \mathrm{eV}$, which enhances the absorption and allows boosting the efficiency of the device. 


\subsubsection{External Quantum Efficiency (EQE) of $\mathrm{CuGaS}_{2}$ :Cr solar cell}

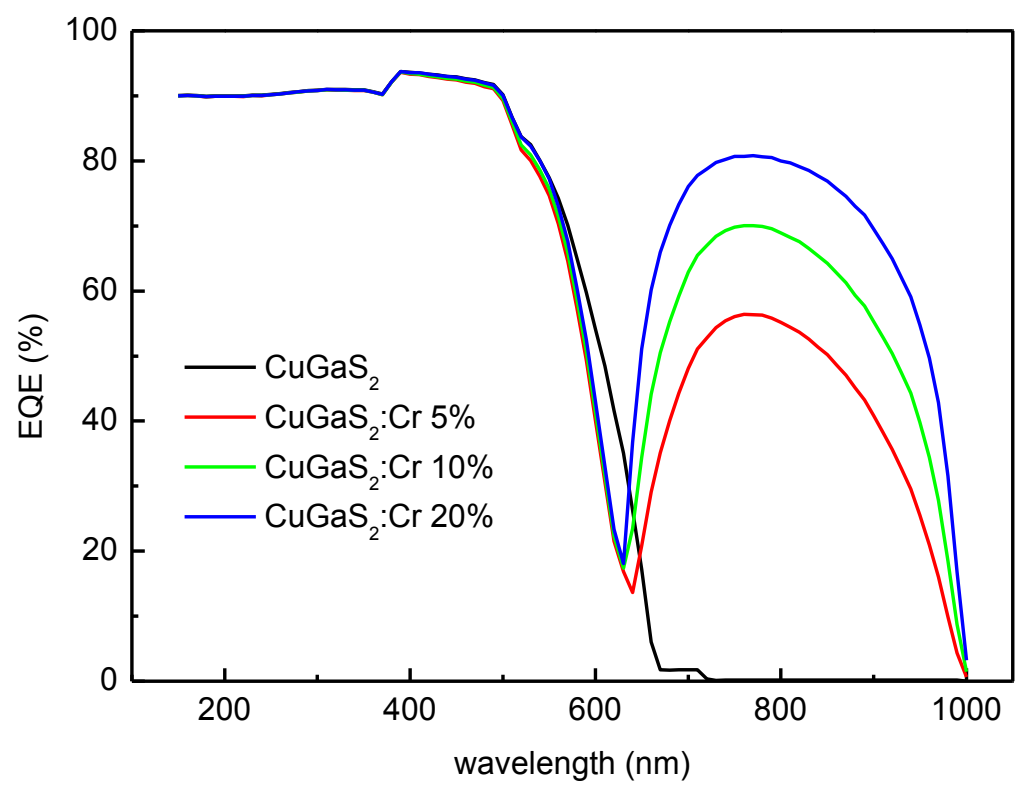

Figure 5.7. $\mathrm{EQE}$ for $\mathrm{Mo} / \mathrm{CuGaS}_{2}: \mathrm{Cr} / \mathrm{CdS} / \mathrm{ZnO}$ solar cells with different $\mathrm{Cr}$ contents under standard $\mathrm{AM} 1.5$ illumination.

Figure 5.7 shows the External Quantum Efficiency (EQE) under AM1.5 illumination for $\mathrm{CuGaS}_{2}: \mathrm{Cr}$ solar cells with a different $\mathrm{Cr}$ content ranging from 0 to $20 \%$. The $\mathrm{EQE}$ is the ratio of the amount of charge carriers collected by the solar cell with respect to the amount of incident photon energy on the solar cell. The EQE for pure $\mathrm{CuGaS}_{2}$ falls to zero for wavelengths longer than $620 \mathrm{~nm}$, which corresponds to the band gap of the absorber (2.2 $\mathrm{eV})$. However, due to the absorption of the IGB, a rise in EQE is observed within the 620$1000 \mathrm{~nm}$ range. This increase in $\mathrm{EQE}$ is related to the absorption of sub-band gap photons associated to the IGB and the general rule is: the higher the Cr content, the higher the EQE in the region below the band gap. The key goal of this research was to improve the performance of solar cells by inserting an IGB to cover a wider wavelength range. 


\subsubsection{Current and Voltage characteristics of $\mathrm{CuGaS}_{2}: \mathrm{Cr}$ thin film solar cells}

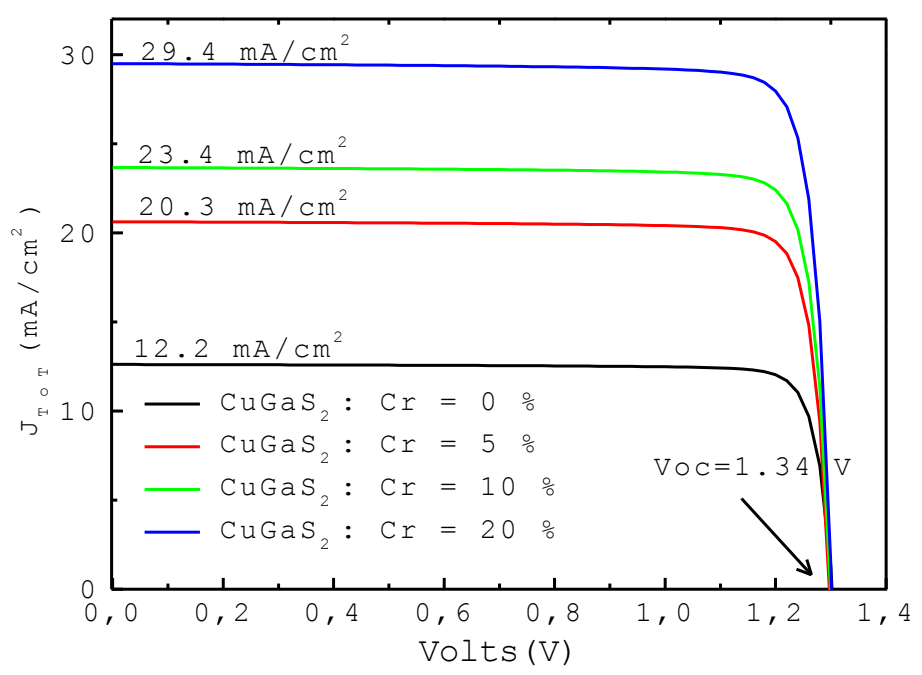

Figure 5.8. $\mathrm{J}-\mathrm{V}$ characteristics of $\mathrm{CuGaS}_{2}$ : $\mathrm{Cr}$ thin film solar cells with various $\mathrm{Cr}$ contents.

Figure 5.8 shows the $\mathrm{J}-\mathrm{V}$ characteristic of solar cells for $\mathrm{CuGaS}_{2}$ absorbers with various Cr contents. Under AM1.5 illumination, the short circuit current $\left(\mathrm{J}_{\mathrm{sc}}\right)$ depends on the $\mathrm{Cr}$ content in the $\mathrm{CuGaS}_{2}$ absorber layer. The short circuit current increases with regard to the $\mathrm{Cr}$ percentage. For $\mathrm{Cr} 0 \%$, the $\mathrm{CuGaS}_{2}$ absorber gives $\mathrm{J}_{\mathrm{sc}}=12.6 \mathrm{~mA} / \mathrm{cm}^{2}$, and $\mathrm{J}_{\mathrm{sc}}$ increases proportionally to the $\mathrm{Cr}$ content of up to $29.41 \mathrm{~mA} / \mathrm{cm}^{2}$ for $\mathrm{Cr} 20 \%$. $\mathrm{Cr} 5 \%, 10 \%$, and $20 \%$ means that the remaining $\mathrm{Ga}$ atoms are 95,90 and $80 \%$ with respect to $\mathrm{Ga}$ atoms in pure $\mathrm{CuGaS}_{2}$ absorbers assuming that all $\mathrm{Cr}$ atoms are substituting $\mathrm{Ga}$ atoms. Unfortunately, this cannot be inferred from EDS analysis.

Table 5.1 displays the main photovoltaic parameters for the studied devices in relation to the $\mathrm{Cr}$ content. Both, the open circuit voltage $(\mathrm{Voc}=1.34 \mathrm{~V})$ and the fill factor $(\mathrm{FF}=89.5)$ remain constant with the amount of Cr. However, the short circuit current (Jsc) dramatically increases with the Cr content, and as a result the photo conversion efficiency (PCE) increases from $14.73 \%$ for the $\mathrm{CuGaS}_{2}$ absorber layer without $\mathrm{Cr}$ to $34.00 \%$ for $\mathrm{CuGaS}_{2}: \mathrm{Cr}(20 \%)$ absorbers. This increase in the PCE is directly related to the effectiveness of the intermediate band for absorbing photons with energies below the band gap. 


\begin{tabular}{|c|c|c|c|c|}
\hline Cr (\%) & Voc (Volt) & Jsc $\left(\mathrm{mA} / \mathrm{cm}^{2}\right)$ & FF (\%) & PCE (\%) \\
\hline 0 & 1.344 & 12.22 & 89.7 & 14.73 \\
\hline 5 & 1.339 & 20.31 & 89.5 & 24.35 \\
\hline 10 & 1.341 & 23.38 & 89.5 & 28.07 \\
\hline 20 & 1.343 & 29.41 & 89.5 & 34.00 \\
\hline
\end{tabular}

Table 5.1: Output parameters of the modeled $\mathrm{Mo} / \mathrm{CuGaS}_{2}: \mathrm{Cr} / \mathrm{CdS} / \mathrm{ZnO}$ thin film solar cell with various $\mathrm{Cr}$ content.

\subsubsection{Current and Voltage characteristics of $\mathrm{CuGaS}_{2}: \mathrm{Cr}$ thin film solar cell with different neutral defects.}

In the $\mathrm{CuGaS}_{2}$ lattice, $\mathrm{Cr}$ atoms should act as a neutral defect and would then hinder the movement of the carriers. Therefore, Cr doping add two effects; a) increasing the photon harvesting through the related IGB, and b) hindering the carriers drift as the doping modifies the crystal lattice. In order to take into account both effects, we calculated the photovoltaic parameters for $\mathrm{CuGaSe}_{2}: \mathrm{Cr}$ devices for an increasing concentration of neutral defects.

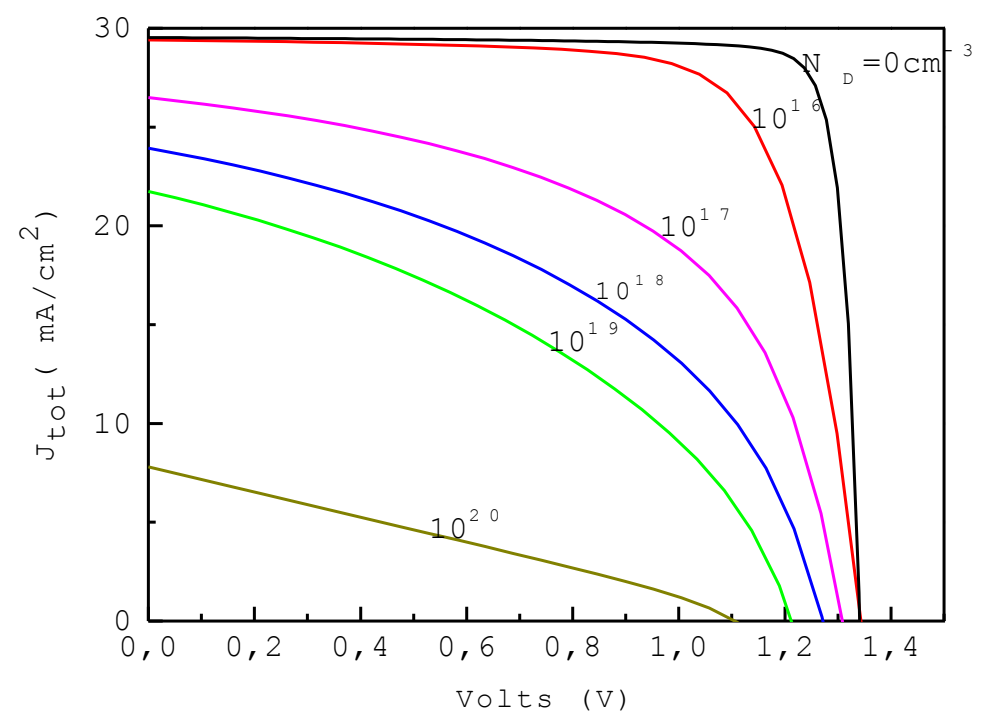

Figure 5.9. J-V characteristics of solar cells based on $\mathrm{CuGaS}_{2}: \mathrm{Cr} 20 \%$ absorbers with different amounts of neutral defects. 
Figure 5.9 shows the J-V curves for PV devices based on $\mathrm{CuGaSe}_{2}: \mathrm{Cr}$ absorbers with an increasing concentration of Cr-related neutral defects. Several features can be seen in these J-V curves: a) increasing neutral defects results in a drop of Voc, b) Jsc is also decreased as the number of neutral defects increases. As a result, PCE drops drastically with the amount of neutral defects. The photovoltaic parameters of such devices in relation to the neutral defects concentration are summarized in Table 5.2.

\begin{tabular}{|c|c|c|c|c|}
\hline $\begin{array}{c}\text { Neutral } \\
\text { Defects }\left(\mathrm{cm}^{-3}\right)\end{array}$ & Voc (Volt) & $\begin{array}{c}\text { Jsc } \\
\left(\mathrm{mA} / \mathrm{cm}^{2}\right)\end{array}$ & FF (\%) & PEC (\%) \\
\hline 0 & 1.34 & 29.41 & 89.70 & 34.00 \\
\hline $10^{16}$ & 1.34 & 29.32 & 70.90 & 30.29 \\
\hline $10^{17}$ & 1.30 & 26.48 & 51.71 & 17.80 \\
\hline $10^{18}$ & 1.27 & 23.92 & 42.70 & 12.97 \\
\hline $10^{19}$ & 1.21 & 21.74 & 38.82 & 10.21 \\
\hline $10^{20}$ & 1.10 & 7.80 & 26.34 & 2.26 \\
\hline
\end{tabular}

Table 5.2: Output parameters of the modeled $\mathrm{Mo} / \mathrm{CuGaS}_{2} \mathrm{Cr} / \mathrm{CdS} / \mathrm{ZnO}$ thin film solar cell with neutral defects.

By introducing neutral defects, the relationship between the PCE and defects is inverse. When the neutral defect concentration increases from $10^{16}$ to $10^{20} \mathrm{~cm}^{-3}$, the PCE decreases from 34 to $2.3 \%$, which means that the performance of the photovoltaic device is very sensitive to neutral defects. Cr-doping improves photon harvesting and, consequently, the short circuit current but, simultaneously, spreads the concentration of neutral defects that obstruct the extraction of carriers to the external load. 


\section{Conclusions}

$\mathrm{CuGaS}_{2}$ thin films were obtained by sulfurization at $400{ }^{\circ} \mathrm{C}$ for $10 \mathrm{~min}$ of previously electro-deposited $\mathrm{CuGaSe}_{2}$ precursor films. The shift observed in X-ray diffraction peaks and the widening of the optical bandgap from 1.66 to $2.20 \mathrm{eV}$ confirm the conversion of $\mathrm{CuGaSe}_{2}$ into $\mathrm{CuGaS}_{2}$.

After partial substitution of $\mathrm{Ga}$ by $\mathrm{Cr}$ atoms an absorption band below the gap is observed. This in-gap band is centered at about $1.63 \mathrm{eV}$ above the valence band. Apart from transitions from the VB to the $\mathrm{CB}$, the IGB band in $\mathrm{CuGaS}_{2}$ : $\mathrm{Cr}$ films allows the absorption of two subband gap photons and promotes electrons from the VB to the $\mathrm{CB}$ via the intermediate IGB. As a result, the absorption coefficient of the IGB absorber extends to longer wavelength region.

Using the experimental absorption coefficient obtained for $\mathrm{CuGaS}_{2}: \mathrm{Cr}$ films with $5 \%$ of Ga atoms being substituted by $\mathrm{Cr}$, we performed numerical simulations to assess the behavior of a solar cell based on $\mathrm{CuGaS}_{2}: \mathrm{Cr}$ absorbers for various amounts of $\mathrm{Cr}$. The absorption due to the IGB dramatically increases the short circuit current of the solar cell, and the photo conversion efficiency also grows from $14.7 \%$ for the $\mathrm{CuGaS}_{2}$ absorber layer without $\mathrm{Cr}$ to $34 \%$ for the $\mathrm{CuGaS}_{2}: \mathrm{Cr}$ absorber layer with $20 \% \mathrm{Cr}$ content. However, as the amount of neutral defects related to $\mathrm{Cr}$ increases, the efficiency of devices diminishes, showing that the PCE for IGB-absorbers is very sensitive to the presence of neutral defects. 
This page intentionally left blank 


\section{Chapter 6}

\section{Conclusion and future wok out look}

A significant progress in efficiency gains have been made over the past decade, CIGS/CdTe/CZTS large-scale manufacturing has struggled to get off the ground. Production of CIGS has been increasing in recent years, but not on the same scale as silicon. While silicon solar cells have had the benefit of piggy-backing the microprocessor industry and utilizing the advances in manufacturing and fabrication technology, CIGS has developed entirely differently. Most groups researching CIGS must develop their own processes and tools to study the material, which makes it challenging for newcomers to the field. As new chalcogenide materials mature and spreads across many disciplines, hopefully the technology will be consolidated to assist those who wish to pursue this attractive technology and continue researching these complex, but highly useful materials.

$\mathrm{Cu}, \mathrm{In}, \mathrm{Ga},\left(\mathrm{Se}_{2}, \mathrm{~S}_{2}\right)$ have been synthesized and used as precursors for the deposition of ternary $\left(\mathrm{CuInSe}_{2}\right.$ and $\left.\mathrm{CuGaSe}_{2}\right)$ and quaternary $\left(\mathrm{CuInGaSe}_{2}\right)$ metal chalcogenide thin films and nanoparticles. Thin films of $\mathrm{CuGa}(\mathrm{Se}, \mathrm{S})_{2}, \mathrm{CdZnS}$ and related materials were deposited by electrochemical deposition and chemical bath deposition, respectively. These techniques offer good control over size, morphology and stoichiometric composition of the materials. Deposited materials were characterized by using optical spectroscopy, powder X-ray diffraction (XRD), scanning electron microscopy (SEM), atomic force microscopy (AFM), transmission electron microscopy (TEM), and energy dispersive Spectroscopy (EDS) and photoelelectrochemical (PEC) analysis.

$\mathrm{CuGaSe}_{2}$ and $\mathrm{CuGaS}_{2}$ thin films suitable for solar cells were successfully prepared by electrodeposition on ITO and Mo-coated glass substrates. $\mathrm{CuGaSe}_{2}$ thin films were deposited from an aqueous electrolyte containing the suitable precursors. Annealing in Se atmosphere at $450{ }^{\circ} \mathrm{C}$ dramatically improves the crystallinity of $\mathrm{CuGaSe}_{2}$ films. Understanding the mechanism of $\mathrm{CuGa}(\mathrm{S}, \mathrm{Se})_{2}$ formation is an important step in improving production and device efficiencies. $\mathrm{CuGaS}_{2}$ films were obtained by subsequent sulfurization at $450{ }^{\circ} \mathrm{C}$ in presence of molecular sulfur of as-deposited $\mathrm{CuGaSe}_{2}$ layers. Crystallite sizes of about 43$48 \mathrm{~nm}$ were obtained for both thermally treated $\mathrm{CuGaSe}_{2}$ and $\mathrm{CuGaS}_{2}$ films. 
When annealing in sulfur atmosphere two processes take place, conversion of Se in to S leading the formation of $\mathrm{CuGaS}_{2}$ thin films and improvement of its crystallinity. The replacement of Se by $\mathrm{S}$ is inferred by the changes observed in the $\mathrm{X}$ ray diffractogram and by the shift of the optical bandgap from $1.66 \mathrm{eV}$ for $\mathrm{CuGaSe}_{2}$ to $2.20 \mathrm{eV}$ for $\mathrm{CuGaS}_{2}$.

The shift observed in X-ray diffraction peaks and the widening of the optical bandgap from 1.66 to $2.20 \mathrm{eV}$ confirm the conversion of $\mathrm{CuGaSe}_{2}$ into $\mathrm{CuGaS}_{2}$. Cr-doping was achieved by adding $\mathrm{Cr}^{3+}$ to the starting electrolyte. The effectiveness of $\mathrm{Cr}$-doping was inferred from the presence of $\mathrm{Cr}$ in $\mathrm{CuGaS}_{2}$ layers and the optical detection of a sub-bandgap absorption band. According to EDS measurements the amount of $\mathrm{Ga}$ atoms substituted by $\mathrm{Cr}$ ranges from 4 to $8 \%$. Further, an intermediate absorption band centred at about $1.63 \mathrm{eV}$ above the valence band is observed in $\mathrm{CuGaS}_{2}: \mathrm{Cr}$ films. The intermediate band in $\mathrm{CuGaS}_{2}: \mathrm{Cr}$ films would allow the absorption of photons with energy higher than the bandgap $\left(\mathrm{E}_{\mathrm{g}}\right)$ and also the absorption of two lower energy photons, which promote electrons from the VB to the IB and from the IB to the $\mathrm{CB}$, respectively. Therefore this intermediate band associated to $\mathrm{Cr}$-doping in $\mathrm{CuGaS}_{2}$ may allow a higher current to be obtained at the voltage corresponding to the energy gap value, so increasing the overall efficiency of the solar cell. As a result, the absorption coefficient of the IGB absorber extends to longer wavelength region.

Using the experimental absorption coefficient obtained for $\mathrm{CuGaS}_{2}: \mathrm{Cr}$ films with $5 \%$ of Ga atoms being substituted by $\mathrm{Cr}$, we performed numerical simulations to assess the behaviour of a solar cell based on $\mathrm{CuGaS}_{2}$ : $\mathrm{Cr}$ absorbers for various amounts of $\mathrm{Cr}$. The absorption due to the IGB dramatically increases the short circuit current of the solar cell, and the photo conversion efficiency also grows from $14.7 \%$ for the $\mathrm{CuGaS}_{2}$ absorber layer without $\mathrm{Cr}$ to $34 \%$ for the $\mathrm{CuGaS}_{2}: \mathrm{Cr}$ absorber layer with $20 \% \mathrm{Cr}$ content. However, as the amount of neutral defects related to $\mathrm{Cr}$ increases, the efficiency of devices diminishes, showing that the PCE for IGB-absorbers is very sensitive to the presence of neutral defects.

$\mathrm{CdZnS}$ thin films with different $\mathrm{Zn}$ contents have been deposited on ITO substrate by Chemical Bath Deposition. XRD patterns confirm that the CdZnS films have polycrystalline structure and exhibit the same hexagonal structure of CdS films. FESEM images of CdZnS thin films show uniform distribution of homogeneous fine particles. The density of grain boundaries seems to decrease with the increase of $\mathrm{Zn}$ content. The grain sizes observed by 
AFM of the CdZnS thin films vary between 173.2 and $249.3 \mathrm{~nm}$. The average surface roughness of the CdZnS thin films have been determined to vary between 23.5 and $98.1 \mathrm{~nm}$. The optical properties, such as transmittance and the energy band gap structure of CdS, are strongly affected by increasing $\mathrm{Zn}$ content, which is the cause of the blue shift observed in the optical band gap from $\approx 2.42$ to $3.25 \mathrm{eV}$ as the $\mathrm{Zn}^{2+}$ compositional parameter increased in the chemical bath. In the photo electrochemical analysis, a significant promotion in photocurrent intensity was observed for different $\mathrm{Zn}$ concentration. PEC study suggest that the incorporated of $\mathrm{Zn}$ increases the conductivity of $\mathrm{CdS}$ which enhances the photocurrent generation are suitable to be used as buffer or window layers in optoelectronic devices such as CIGS and CdTe solar cells due to their higher transparency and better surface morphology.

\section{Outlook for the future work}

There is a lot of possibility to find cheaper materials with high optical and electrical properties to replace the existing technologies. CIGS thin films haves a great potential to meet the challenges of energy requirements in the 21st century and beyond. Cutting-edge research for improved designs on the electrical and optical aspects is needed to make them cost effective for domestic applications. The CIGS solar cells are currently used for terrestrial applications.

However, it is becoming more popular for commercial applications with the improvement in thin film technology and exponential reduction in fabrication cost.

The fabrication methods such as electrodeposition and chemical bath deposition etc. are very suitable and inexpensive techniques to improve the efficiency and to bring down the fabrication cost of thin films solar cell devices.

The CIGS surface layer is very important for a reduction of the charge recombination at the buffer/CIGS interface. Therefore, an investigation of this layer in dependence on CIGS preparation parameters is essential.

Complete CIGS solar cells should also be studied in the future, $\mathrm{CdS}$ and $\mathrm{CdZnS}$ as windows layer using the same Mo coated glass substrate structures optimized for solar cells. Further experiments should be carried out with lower Ga content values for the purpose of increasing JSC significantly while making relatively smaller sacrifices in VOC and FF, such that the 
overall device performance improves. A second possibility of research for optimizing thin CIGS solar cells would be to reduce the thickness of the window CdS layer. JSC can be improved by reducing the absorption in the window layer by reducing its thickness,

The most promising future approach for evaluating the effects of $\mathrm{Zn}$ thin films can be further investigated by using different concentrations of $\mathrm{Zn}$ for the CIGS windows layer. Optimization of the conditions like post annealing treatment time, $\mathrm{Zn}^{2+}$ concentration and temperature, is a key to further improve the performance of the $\mathrm{CdZnS}$ buffer solar cell. It is possible that increasing the $\mathrm{Zn}$ concentration would lead to even lower resistivity of the $\mathrm{CdZnS}$ thin film. It is of benefit to reduce the resistivity so that the same sheet resistance could be achieved with less thickness. This would reduce the material cost and also the processing time. Also, thinner $\mathrm{ZnO}$ window layer could reduce the photon absorption and optical interference if appropriate thickness is chosen. For good uniformity on large size substrate, the $\mathrm{ZnO}$ thickness variation should be carefully studied.

The results of this work indicate that the role of the chemical bath deposited buffer is rather to save the CIGS inverted surface layer than modify it. Thus, the application of other "soft" deposition methods should have quite a high potential.

A combination of experimental and numerical tools could be of help to both individual techniques.

In an additional extension to the I V simulations presented in Chapter 5, which could be further improve by changing the different parameters of absorber, buffer and windows layers, like thickness, donor and accepter concentration etc.

Furthermore suggestion is for the future work, to insert an intermediate band with in the CIGS thin films to cover the lower wave length photons and maximize the photons absorption and to extract the recombination losses in the device. 


\section{References.}

[1] Energy Information Administration, U.S. Department of Energy, International Energy Annual, 2005 (EIA, U.S. Department of Energy, Washington DC. 2005)

[2] https://www.iea.org/publications/freepublications/publication/pv_roadmap.pdf.

[3] Various Authors (2011). 'Key World Energy Statistics'. Tech. rep., International Energy Agency. URL http://www.iea.org/textbase/nppdf/free/2011/key_world_energy_stats.pdf.

[4] D. Williams, Sun Fact Sheet, retrieved 2010-09-13 from NASA's webpage:

http://nssdc.gsfc.nasa.gov/planetary/factsheet/sunfact.html.

[5] World Energy Resources 2013 Survey

[6] N. G. Dhere, Solar Energy Materials \& Solar Cells, 2007, 91, 1376.

[7] Martin A. Green, Keith Emery, Yoshihiro Hishikawa, Wilhelm Warta, and Ewan D. Dunlop (2011). 'Solar cell efficiency tables (Version 38)'. Progress in Photovoltaics: Research and Applications 19 (5), pp. 565-572. doi: 10.1002/ pip.1150.

[8] S. M. Sze and Kwok K. Ng, Physics of Semiconductor Devices (John Wiley \& Sons Inc., Hoboken, New Jersey, 2007), 3 ed.

[9] T. Torndahl, C. Platzer-Bjorkman, J. Kessler, and M. Edoff (2007). 'Atomic layer deposition of Zn1-xMgxO buffer layers for Cu(In,Ga)Se2 solar cells'. Progress in Photovoltaics: Research and Applications 15 (3), pp. 225-235. doi: 10.1002/pip.733.

[10] Williams, R. Becquerel photovoltaic effect in binary compounds. The journal of Chemical physics, 32(5), (1960) 1505-1514

[11] K. A. Tsokos, Physics for the IB Diploma Fifth edition, Cambridge University Press, Cambridge, 2008.

[12] Nelson, Jenny. Physics of Solar Cells. Imperial College Press, UK, 2008.

[13] M. Mezher, R. Garrid, L. M. Mansfield, K, Horsley, L. Weinhardt, D. A. Duncan, M. Blum, S. G. Rosenberg, M. Bar, K. Ramanathan and C. Heske, Electronic structure of the $\mathrm{Zn}(\mathrm{O}, \mathrm{S}) / \mathrm{Cu}(\mathrm{In}, \mathrm{Ga}) \mathrm{Se} 2$ thin-film solar cell interface, Prog. Photovolt: Res. Appl. 24 (2016) 1142-1148.

[14] B.L. Capehart, Encyclopedia of Energy Engineering and Technology-Volume 3, Taylor [15] F. C. Krebs, "Stability and Degradation of Organic and Polymer Solar Cells", John Wiley \& Sons, May 1, 2012, ISBN 1119952514, 9781119952510. 
[16] Kazmerski, L. L. Solar photovoltaics R\&D at the tipping point: A 2005 technology overview. Journal of Electron Spectroscopy and Related Phenomena, 150(2) (2006)105-135. [17] I. Bhattacharya, S. Y. Foo, Indium phosphide, indium-gallium-arsenide and indiumgallium-antimonide based high efficiency multijunction photovoltaics for solar energy harvesting, Quality Electronic Design, 2009. ASQED 2009. 1st Asia Symposium on, vol., no., pp.237-241, 15-16 July 2009.

[18] A. Carrete, M. Placidi, A. Shavel, A. Pérez Rodríguez, A. Cabot; Spray-deposited CuIn1-xGaxSe2 solar cell absorbers: Influence of spray deposition parameters and crystallization promoters; Phys. Stat. Sol. (a) 212 (2015) 67-71.

[19] VS. Saji, Ik-Ho. Choi, CW. Lee; CIGS thin film solar cells by electrodeposition, Solar Energy. 86 (2011) 2666-2678

[20] S. Aksu, S. Pethe, A. Kleiman-Shwarsctein, S. Kundu, M. Pinarbasi, in: 38th IEEE Photovotaics Specialists Conference, (2012) 3092-3097.

[21] Chopra, K.L., Paulson, P.D., Dutta, V., 2004. Thin film solar cells: an overview. Prog. Photovolt. Res. Appl. 12, 69-92.

[22] K.T.R. Reddy, P.J. Reddy, "Studies of ZnxCd1-xS films and ZnxCd1-xS/GuGaSe2 heterojunction solar cells", Journal of Physics D: Applied Physics, vol. 25, pp. 1345-1348, 1992.

[23] R.N. Bhattacharya, M.A. Contreras, B. Egaas, R.N. Noufi, A. Kanevce, J.R. Sites, "High efficiency thin-film CuIn1-xGaxSe2 photovoltaic cells using Cd1-xZnxS buffer layer", Applied Physics Letters, vol. 89, pp. 253503/1-253503/2, 2006.

[24] Ramanathan, K., Contreras, M.A., Perkins, C.L, Asher, S., Hasoon, F.S., Keane, J., Young, D., Romero, M., Metzger, W., Noufi, R., Ward, J., Duda, A., 2003. Properties of 19.2\% efficiency ZnO/CdS/CuInGaSe2 thin-film solar cells. Prog. Photovolt. Res. Appl. 11, 225-230.

[25] C.H. Huang, Sheng S. Li, W.N. Shafarman, et al., Sol. Energ. Mater. Sol. Cells 69 (2001) 131.

[26] O. Lundberg, J. Lu, A. Rockett, et al., J. Phys. Chem. Solids 64 (2003) 1499.

[27] J.M.Merino, M. Leon, F. Rueda, Thin Solid Films 361-362 (2000) 22.

[28] Adolf Goetzberger, Christopher Hebling, Sol. Energ. Mater. Sol. Cells 62 (2000) 1. 
[29] Ho Keun Song, Soo Gil Kim, Hyeong Joon Kim, et al., Sol. Energ. Mater. Sol. Cells 75 (2003) 145.

[30] A. Kampmann, V. Sittinger, J. Rechid, Thin Solid Films 361-362 (2000) 309.

[31] M.E. Calixtoa, R.N. Bhattacharya, P.J. Sebastian, Sol. Energ. Mater. Sol. Cells 55 (1998) 23.

[32] Bhattacharya, R.N., Ramanathan, K., 2004. Cu(InGa)Se2 thin film solar cells with buffer layer alternative to CdS. Sol. Energy 77, 679-683.

[33] Schock, H.W., Noufi, R., 2000. CIGS-based solar cells for the next millennium. Prog. Photovolt. Res. Appl. 8, 151-160.

[34] U. Rau and H. W. Schock, in Solar Cells: Materials, Manufacture and Operation, eds. T. Markvart and L. Castaner, Elsevier, Great Britain, 2005, pp. 305-349.

[35] H.-W. Schock, R. Noufi: Prog. Photovolt. Res. Appl. 8 (2000) 151-160. 8(2000) 151160. (2001) 135-140.

[36] N. Naghavi, D. Abou-Ras, N. Allsop, N. Barreau, S. Bücheler, A. Ennaoui, C.-H. Fischer, C. Guillen, D. Hariskos, J. Herrero, R. Klenk, K. Kushiya, D. Lincot, R. Menner, T. Nakada, C. Platzer-Björkman, S. Spiering, A.N. Tiwari, T. Törndahl: Prog. Photovolt. Res. Appl. 18 (2010) 411-433.

[37] R. Klenk, Thin Solid Films 387 (2001) 135-140.

[38] P. Wurfel, Physics of solar cells: from basic principles to advanced concepts, WILEYVCH, Germany, 2009.

[39] A. Niemegeers, M. Burgelman and A. De Vos, On the CdS/CuInSe2 band discontinuity, Applied Physics Letters, 67 (1995) p. 843-845.

[40] R. Herberholz, V. Nadenau, U. Rühle, C. Köble, H. Schock and B. Dimmler, Prospects of wide-gap chalcopyrites for thin film photovoltaic modules, Solar Energy Materials and Solar Cells, 49 (1997) p. 227-237.

[41] N. Naghavi, D. Abou-Ras, N. Allsop, N. Barreau, S. Bücheler, A. Ennaoui, C.- H. Fischer, C. Guillen, D. Hariskos, J. Herrero, R. Klenk, K. Kushiya, D. Lincot, R. Menner, T. Nakada, C. Platzer-Björkman, S. Spiering, A.N. Tiwari and T. Törndahl, Buffer layers and transparent conducting oxides for chalcopyrite $\mathrm{Cu}(\mathrm{In}, \mathrm{Ga})(\mathrm{S}, \mathrm{Se}) 2$ based thin film photovoltaics: present status and current developments, Progress in Photovoltaics: Research and Applications, 18 (2010) p. 411-433. 
[42] D. Hariskos, S. Spiering and M. Powalla, Buffer layers in Cu(In, Ga)Se2 solar cells and modules, Thin Solid Films, 480-481 (2005) p. 99-109.

[43] S. Siebentritt, M. Igalson, C. Persson and S. Lany, The electronic structure of chalcopyrite's-bands, point defects and grain boundaries, Progress in Photovoltaics: Research and Applications, 18 (2010) p. 390-410.

[44] R. Herberholz, V. Nadenau, U. Rühle, C. Köble, H. Schock and B. Dimmler, Prospects of wide-gap chalcopyrite's for thin film photovoltaic modules, Solar Energy Materials and Solar Cells, 49 (1997) p. 227-237.

[45] Gaponenko, S.V., Optical Properties of Semiconductor Nanocrystals. 1998. 240 pp.

[46] Halperin, W.P., Quantum size effects in metal particles. Reviews of Modern Physics, 1986. 58(3): p. 533.

[47] A. L. Fahrenbruch and R. H. Bube, in 'Fundamentals of Solar Cells: Photovoltaic Solar Energy Conversion', Academic Press, New York, 1983.

[48] Alex Carrete, Marcel Placidi, Alexey Shavel, Alejandro Pérez-Rodriguez, and Andreu Cabot, Phys. Status Solidi A, 1-5 (2014) / DOI 10.1002/pssa.201431425

[49] Li Zhang n, Fang-fang Liu, Feng-yan Li, Qing He, Bao-zhang Li, Chang-jian Li, Solar Energy Materials \& Solar Cells 99 (2012) 356-361

[50] Mattox, Donald M. "Handbook of physical vapor deposition (PVD)." Processing: Film Formation, Adhesion, Surface Preparation and Communication Control (1998).

[51] Z.S. Pillai, P.V. Kamat: J. Phys. Chem. 2003, B107, 945.

[52] A. L. Patterson, Phys. Rev., 1939, 56, 978-982.

[53] J. I. Langford and A. J. C. Wilson, J. Appl. Crystallogr., 1978, 11, 102-113.

[54] Leamy, H. J. Charge collection scanning electron microscopy. Journal of Applied Physics, 53(6), R51-R80. (1982).

[55] Eaton, P., \& West, P. Atomic force microscopy. Oxford University Press. (2010).

[56] Bak, A., Choi, W., \& Park, H. (2011). Enhancing the photoelectrochemical performance of hematite ( $\alpha-\mathrm{Fe} 2$ O3) electrodes by cadmium incorporation. Applied Catalysis B: Environmental, 110, 207-215.

[57] A. J. Bard, L. R. Faulkner, Electrochem. Methods: Fundamental and Application, VHC, New York, USA 1995.

[58] Nelson, Jenny. Physics of Solar Cells. Imperial College Press, UK, 2008. 
[59] Honsberg, C., \& Bowden, S. (2010). Pvcdrom. Internet: http://pveducation. org/pvcdrom, [Jun 5, 2013].

[60] Fonash, S. J, Solar cell device physics, 2nd ed.; Elsevier: Amsterdam, 2010.

[61] X. X. Liu and J. R. Sites, "Solar cell collection efficiency and its variation with voltage, J. Appl. Phys., vol. 75, pp. 577-581, 1994.

[62] Y. Hamakawa, Ed., Thin-film solar cells: next generation photovoltaics and its applications. Berlin and Heidelberg: Springer, 2004.

[63] W. Witte, D. Hariskos, and M. Powalla, "Comparison of charge distributions in CIGS thin-film solar cells with $\mathrm{ZnS} /(\mathrm{Zn}, \mathrm{Mg}) \mathrm{O}$ and CdS/i-ZnO buffers," Thin Solid Films, vol. 519, pp. $7549-7552,2011$.

[64] G. Zoppi, I. Forbes, R. W. Miles, P. J. Dale, J. J. Scragg, and L. M. Peter, "Cu2ZnSnSe4 thin film solar cells produced by selenisation of magnetron sputtered precursors," Prog. Photovolt: Res. Appl., vol. 17, pp. 315-319, 2009.

[65] G. Rosa, A. Bosio , D. Menossi and N. Romeo,Energy, 9(5) 2016, 354

[66] J.L. Bi, J.P. Ao, M.J. Jeng, L.Y. Yao, S.S. Gao, G.Z. Sun, Q. He, Z. G., Y. Sun, Y.L. Xiao, L.B. Chang, Sol. Energy Mater. Sol. Cells, 159 (2017) 352-361

[67] K.J. Yang, D.H. Son, S.J. Sung, J.H. Sim, Y.I. Kim, S.N. Park J. Mater. Chem. A, 4 (2016) 1051-1058

[68] S. Sadewasser, P.M.P. Salome, H. Rodriguez-Alvarez Sol. Energy Mater. Sol. Cells, 159 (2017), 496-502

[69] M.D. Heinemann, F. Ruske, D. Greiner, A.R. Jeong, M. Rusu, B. Rech, R. Schlatmann, C.A. Kaufmann Sol. Energy Mater. Sol. Cells, 150 (2016) 76-81

[70] K.W. Cheng, K. Hinaro, M.P. Antony Sol. Energy Mater. Sol. Cells, 151 (2016), pp. $120-130$

[71] M. Mezher, R. Garrid, L. M. Mansfield, K, Horsley, L. Weinhardt, D. A. Duncan, M. Blum, S. G. Rosenberg, M. Bar, K. Ramanathan and C. Heske, Electronic structure of the $\mathrm{Zn}(\mathrm{O}, \mathrm{S}) / \mathrm{Cu}(\mathrm{In}, \mathrm{Ga}) \mathrm{Se} 2$ thin-film solar cell interface, Prog. Photovolt: Res. Appl. 24 (2016) $1142-1148$

[72] Rau, U.; Taretto, K.; Siebentritt, S. Grain Boundaries in Cu(In,Ga)(Se,S)2 Thin-Film Solar Cells. Appl. Phys. A: Mater. Sci. Process. 2009, 96, 221-234. 
[73] Persson, C.; Zunger, A. Anomalous Grain Boundary Physics in Polycrystalline CuInSe2: The Existence of a hole Barrier. Phys. Rev. Lett. 2003, 91, 266401.

[74] Siebentritt, S.; Sadewasser, S.; Wimmer, M.; Leendertz, C.; Eisenbarth, T.; Lux-Steiner, M. C. Evidence for a Neutral Grain-Boundary Barrier in Chalcopyrites. Phys. Rev. Lett. 2006, 97, 146601.

[75] Hunger, R.; Pettenkofer, C.; Scheer, R. Dipole Formation and Band Alignment at the Si(111)/CuInS2 Heterojunction. J. Appl. Phys. 2002, 91, 6560-6570.

[76] Hofmann, A.; Pettenkofer, C. Surface Orientation Dependent Band Alignment for CuInSe2/ZnSe/ZnO. Appl. Phys. Lett. 2011, 98, 113503.

[77] Carrete A, Placidi M, Shavel A, Pérez Rodríguez A, Cabot A (2015) Phys Stat Sol (a) 212:67-71

[78] Saji VS, Choi Ik-Ho, Lee CW (2011) Sol Energy 86:2666-2678

[79] Park MG, Ahn SJ, Yun JH, Gwak J, Cho A, Ahn SK, Shin K, Nam D, Cheong H, Yoon K (2012) J Alloy Compd 513: 68-74

[80] Calixto ME, Sebastian PJ, Bhattacharya RN, Noufi (1999) Sol Energ Mat Sol C 59:7584

[81] Lee H, Lee J-H, Hwang Y-H, Kim Y, (2014) Current Applied Physics 14:18-22

[82] R. N. Bhattacharya K, Rajeshwaar and R. Noufi, J. Electrochem. Soc., 131 (1984) 939

[83] B. Dimmler, H. Dittrich, R. Menner, and H.W. Schock, "Performance and Optimization of Heterojunctions Based on $\mathrm{Cu}(\mathrm{Ga}$,In)Se2", Proceedings of 19th IEEE Photovoltaic Specialist Conference, New York, 1454, 1987.

[84] S.H. Wei, S.B. Zhang and A. Zunger, "Effects of Ga Addition to CuInSe2 on its Electronic, Structural, and Defect Properties", Applied Physics Letters, vol. 72, 3199, 1998. [85] T. Markvart and L. Castaner, "Solar Cells: Materials, Manufacture and Operation "Elsevier Advanced Technology, 2005

[86] M.I. Alonso, M. Garriga, C.A. Durante Rinćon, E.Hernandez and M. Léon, "Optical Functions of Chalcopyrite CuGaxIn1-xSe2 Alloys", Applied Physics A: Materials Science \& Processing, vol. 74, 659, 2002.

[87] M. Bär, W. Bohne, J. Röhrich, E. Strub, S. Lindner, M. C. Lux-Steiner, Ch.H. Fischer, T. P. Niesen and F. Karg, "Determination of the band gap depth profile of the pentenary 
$\mathrm{Cu}(\operatorname{In} 1-X \mathrm{GaX})(\mathrm{SYSe}(1-Y)) 2$ chalcopyrite from its composition gradient", Journal of Applied Physics, 96, 7, 3857, 2004

[88] R. W. Birkmire and E. Eser, "Polycrystalline Thin Film Solar Cells: Present Status and Future Potential”, Annual Review of Material Science, vol. 27, 625, 1997.

[89] T. Dullweber, O. Lundberg, J. Malmstrom, M. Bodegard, L. Stolt, U. Rau, H.W. Schock and J.H. Werner, "Back Surface Band Gap Gradings in Cu(In,Ga)Se2 Solar Cells", Thin Solid Films, vol. 387 (1-2), 11, 2001.

[90] D. Schroeder and A. Rockett, "Electronic Effects of Sodium in Epitaxial CuIn1xGaxSe2", Journal of Applied Physics, vol. 82, 4982, 1997.

[91] T. Nakada, H. Ohno, T. Watanabe, H. Nakazawa, M. Matsui, and A. Kunioka, “Improved Cu(In,Ga)(S,Se)2 Thin Film Solar Cells By Surface Sulfurization”, Solar Energy Materials and Solar Cells, vol. 49, 285, 1997.

[92] Kim D, Kwon Y, Lee D, Yoon S, Lee S, Yoo B (2015) Journal of Electrochemical Society 162:D36-D41

[93] Hou WW, Bob B, Li S, Yang Y (2009) Thin Solid Films 517:6853-6856

[94] Lee J, Lee W, Shrestha NK, Lee DY, Lim I, Kang SH, Nah YC, Lee SH, Yi W, Han SH (2014) Mater Chem Phys 144:49-54

[95] Kim D, Kwon Y, Lee D, Yoon S, Lee S, Yoo B (2015) Journal of Electrochemical Society 162:D36-D41

[96] Hou WW, Bob B, Li S, Yang Y (2009) Thin Solid Films 517:6853-6856

[97] Lee J, Lee W, Shrestha NK, Lee DY, Lim I, Kang SH, Nah YC, Lee SH, Yi W, Han SH (2014) Mater Chem Phys 144:49-54

[98] Yang JY, Lee D, Huh K, Jung SJ, Lee JW, Lee HC, Baek DH, Kim BJ, Kim D, Nam J, Kim GY, Jo W (2015) RSC Adv 5:40719-407257

[99] Lee JH, Song WC, Yi JS, Joonyang K, Han WD, Hawang J (2003) Thin Solid Films 431 432: 349-353

[100] Prabukanthan P, Dhanasekaran R (2007) Cryst Growth Des 7:618-623

[101] Guillemoles JF, Cowache P, Lusson A, Fezzaa K, Boisivon F, Vedel J, Lincot D (1996) J Appl Phys 79:7293-7302

[102] Aguilera I, Palacios P, Wahon P (2010) Sol Energ Mat Sol C 94:1903-1906

[103] Palacios P, Aguilera I, Wahnón P, Conesa JC (2008) J Phys Chem C 112: 9525-9529 
[104] K. L Chopra and S. R. Das, Ch \# 6 "Properties of Thin Films for Solar Cells", Thin Film Solar Cell, Plenum press - New York, Edition, 295, 1983.

[105] D. Haneman, "Properties and Applications of Copper Indium Diselenide", Critical Reviews in Solid State and Materials Sciences, vol. 14, 377, 1988.

[106] I. Kaur, D. Pandya and K. Chopra, "Growth Kinetics and Polymorphism of Chemically Deposited CdS Films", Journal of Electrochemical Society, vol. 127, 943, 1980. [107] K. Djessas, G. Massé, and M. Ibannaim, "CuInS2 Thin Films for Solar Cell Applications", Journal of Electrochemical Society, vol. 147, 1235, 2000.

[108] D.Schmid, M Ruckh, and H. W.Schock, "A Comprehensive Characterization of the Interfaces in Mo/CIS/CdS/ZnO Solar Cell Structures", Solar Energy Materials and Solar cells, vol. 41/42, 281, 1996.

[109] M.A. Contreras, M.J. Romero, B. To, F. Hasoon, R. Noufi, S. Ward and K. Ramanathan, "Optimization of CBD CdS process in high-efficiency $\mathrm{Cu}(\mathrm{In}, \mathrm{Ga}) \mathrm{Se}$-based solar cells", Thin Solid Films, vol. 403, 204, 2002.

[110] J.H.Lee, W.C.Song, J.S.Yi, K.J.Yang, W.D.Han, J.Hwang, Growthand properties of the $C d_{1 \_} X n_{x} S$ thin films for solar cell applications, Thin Solid Films 431-432, 349-353, 2003.

[111] O.P.Agnihotri, B.K.Gupta, Cd $d_{1 \_} X n_{x} S$ films for low cost solar cells, Japanese Journal of Applied Physics 18-317-320, 1979.

[112] J. Zhou, X.Wu, G.Teeter, B.To, Y.Yan, R.G.Dhere, T.A.Gessert, CBD- Cd $d_{1_{-}} Z n_{x} S$ thin films and their application in CdTe solar cells, Physica Status Solidi B24, 1775-778, 2004. [113] S.K. Das, Sol. Energy Mater. Sol. Cells 29, 277, 1993.

[114] T. Edamura, J. Muto, Thin Solid Films 235, 198, 1993.

[115] Ch. Bouchenaki, B. Ullrich, J.P. Zielinger, H. Nguyen Cong, P. Chartier, J. Crystal Growth $101-797,1990$.

[116] T. P. Kumar, S. Saravanakumar, and K. Sankaranarayanan, Effect of annealing on the surface and band gap alignment of CdZnS thin films. Applied Surface Science, 257(6), 19231927, 2011.

[117] M. E. Calixto, A. A. Morales, P. G. Contreras, A. M. L and V. M. Tofino, Chemical Bath Deposited CdSfor CdTe and Cu (In, Ga) Se, Thin Film Solar Cells Processing. (2011). 
[118] H. J. Liu, and Y. C. Zhu, Synthesis and characterization of ternary chalcogenide ZnCdS ID nanostructures. Materials Letters, 62(2), 255-257, 2008.

[119] B. Kumar, P. Vasekar, S. A. Pethe, N. G. Dhere, and G. T. Koishiyev, $Z n_{x} C d_{1-x} S$ as a heterojunction partner for CuIn ${ }_{1-x} \mathrm{Ga} a_{x} S_{2}$ thin film solar cells. Thin Solid Films, 517(7), 2295-2299, 2009.

[120] S. A. Kuhaimi and Z. Tulbah, Electrochemical/Chemical Deposition and EtchingStructural, Compositional, Optical, and Electrical Properties of Solution-Grown $Z n_{x} C d_{1-x} S$ Films. J. Electrochem Soc, 147(1), 214-218, 2000.

[121] X. Wu, J. C. Keane, R. G. Dhere, C. Dehart, A. Duda, T. A. Gessert, and P. Shelton, Proceedings of the 17th European Photovoltaic Solar Energy Conference, 995-1000, 2001. [122] K. R. Reddy and P. J. Reddy, Studies of $\mathrm{Zn}_{x} C d_{1-x} S$ films and $\mathrm{Zn}_{x} C d_{1-x} \mathrm{~S} / \mathrm{CuGaSe} 2$ heterojunction solar cells. Journal of Physics, Applied Physics, 25(9), 1345, 1992.

[123] T. Gruszecki and B. Holmström, Preparation of thin films of polycrystalline CdSe for solar energy conversion I. A literature survey. Sol. Energy Mater. Sol cells, 31(2), 227-234, 1993.

[124] H. L. Jae, S. Y. Jun, J. Y. Kea, H. P. Joon, D .O. Ryum, Thin Solid Films Vol- 431432, 344-348, 2003.

[125] B. Thangaraju, \& P. Kaliannan, Polycrystalline lead tin chalcogenide thin film grown by spray pyrolysis. Crystal Research and Technology, 35(1) (2000), 71-75.

[126] R. N. Bhattacharya, K. Ramanathan, L. Gedvilas and B. Keyes, Cu (In, Ga) Se 2 thinfilm solar cells with $\mathrm{ZnS}(\mathrm{O}, \mathrm{OH}), \mathrm{Zn}-\mathrm{Cd}-\mathrm{S}(\mathrm{O}, \mathrm{OH})$, and $\mathrm{CdS}$ buffer layers. J. Phys. Chem. Solids, 66(11), 1862-1864, 2005.

[127] V. B. Sanap and B. H. Pawar, Optical study of the effect of cadmium sources on nanocrystalline CdS thin films. Chalcogenide Lett, 7, 227-231, 2010.

[128] T. F. Jaramillo, S. H. Baeck, S. A Kleiman. K. S. Choi, G. D. Stucky, M. Farland, E. W. J. Comb. Chem. 7, 264, 2005.

[129] T. F. Jaramillo, S. H. Baeck, S. A. Kleiman, McFarland, E. W. Macromol. Rapid Commun. 25, 297, 2004.

[130] Y. W. Phuana, E. Ibrahima, M. N. Chong, T. Zhua, B. K. Leec, J. D. Ocond, Eng Seng Chana, Applied Surface Science 392, 144-152, 2017. 
[131] X. Chanjuan, Z. Yaojun, Y. Wei, G. Liejin, International Journal of Hydrogen Energy 31 (2006) $2018-2024$

[124] Mezher, M., Garris, R., Mansfield, L. M., Horsley, K., Weinhardt, L., Duncan, D. A.,... \& Heske, C. (2016). Electronic structure of the $\mathrm{Zn}(\mathrm{O}, \mathrm{S}) / \mathrm{Cu}$ (In, Ga) Se2 thin-film solar cell interface. Progress in Photovoltaics: Research and Applications; 24, 1142-1148

[125] Carrete, A., Placidi, M., Shavel, A., Pérez-Rodríguez, A., \& Cabot, A. (2015). Spraydeposited CuIn1-xGaxSe2 solar cell absorbers: Influence of spray deposition parameters and crystallization promoters. physica status solidi (a), 212(1), 67-71.

[126] Saji, V. S., Choi, I. H., \& Lee, C. W. (2011). Progress in electrodeposited absorber layer for CuIn (1-x) GaxSe 2 (CIGS) solar cells. Solar Energy, 85(11), 2666-2678.

[127] Aksu, S., Pethe, S., Kleiman-Shwarsctein, A., Kundu, S., Pinarbasi \& M., in: 38th IEEE Photovoltaics Specialists Conference, (2012) 3092-3097.

[128] Saji, V. S., Lee, S. M., \& Lee, C. W. (2011). CIGS thin film solar cells by electrodeposition. Journal of the Korean Electrochemical Society, 14(2), 61-70.

[129] Wang, W., Yang, J., Zhu, X., \& Phillips, J. (2011). Intermediate-band solar cells based on dilute alloys and quantum dots. Frontiers of Optoelectronics in China, 4(1), 2-11.

[138] Shockley, W., \& Queisser, H. J. (1961). Detailed balance limit of efficiency of $p-n$ junction solar cells. Journal of applied physics, 32(3), 510-519.

[131] Luque, A., \& Marti, A. (1997). Increasing the efficiency of ideal solar cells by photon induced transitions at intermediate levels. Physical Review Letters, 78(26), 5014.

[132] Palacios, P., Sánchez, K., Conesa, J. C., \& Wahnón, P. (2006). First principles calculation of isolated intermediate bands formation in a transition metal-doped chalcopyrite-type semiconductor. physica status solidi (a), 203(6), 1395-1401.

[133] Palacios, P., Sánchez, K., Conesa, J. C., Fernández, J. J., \& Wahnón, P. (2007). Theoretical modelling of intermediate band solar cell materials based on metal-doped chalcopyrite compounds. Thin Solid Films, 515(15), 6280-6284.

[142] Aguilera, I., Palacios, P., \& Wahnón, P. (2010). Enhancement of optical absorption in Ga-chalcopyrite-based intermediate-band materials for high efficiency solar cells. Solar Energy Materials and Solar Cells, 94(11), 1903-1906.

[143] Burgelman, M., Verschraegen, J., Degrave, S., \& Nollet, P. (2004). Modeling thin-film PV devices. Progress in Photovoltaics: Research and Applications, 12(2-3), 143-153. 
[136] Kim, D., Kwon, Y., Lee, D., Yoon, S., Lee, S., \& Yoo, B. (2015). The Effect of Sulfurization Temperature on CuIn (Se, S) 2 Solar Cells Synthesized by Electrodeposition. Journal of the Electrochemical Society, 162(1), D36-D41.

[137] Hou, W. W., Bob, B., Li, S. H., \& Yang, Y. (2009). Low-temperature processing of a solution-deposited CuInSSe thin-film solar cell. Thin Solid Films, 517(24), 6853-6856.

[138] Lee, J., Lee, W., Shrestha, N. K., Lee, D. Y., Lim, I., Kang, S. H. \& Han, S. H. (2014). Influence of encapsulated electron active molecules of single walled-carbon nanotubes on superstrate-type $\mathrm{Cu}(\mathrm{In}, \mathrm{Ga}) \mathrm{Se}_{2}$ solar cells. Materials Chemistry and Physics, 144(1) 49-54. [139] Yang, J., Lee, D., Huh, K., Jung, S., Lee, J., Lee, H. \& Kim, G. (2015). Influence of surface properties on the performance of $\mathrm{Cu}(\mathrm{In}, \mathrm{Ga})(\mathrm{Se}, \mathrm{S})_{2}$ thin-film solar cells using Kelvin probe force microscopy. RSC Advances, 5(51), 40719-40725.

[148] Ullah, S., Mollar, M., \& Mari, B. (2016). Electrodeposition of CuGaSe2. Journal of Solid State Electrochemistry, 20(8), 2251-2257.

[149] Palacios, P., Aguilera, I., Wahnón, P., \& Conesa, J. C. (2008). Thermodynamics of the formation of Ti-and Cr-doped CuGaS2 intermediate-band photovoltaic materials. The Journal of Physical Chemistry C, 112(25), 9525-9529.

[150] Ullah, H., Ullah, S., \& Soucase, B. M. (2014, November). Baseline of numerical simulations for ZnTe based thin-film solar cells. In Energy Systems and Policies (ICESP), 2014 International Conference on (pp. 1-6). IEEE.

[151] Luque, A. Marti, A. Physical Review Letters 1997, 78, 5014-5017.

[152] Luque, A. Marti, A. Progress in Photovoltaics 2001, 9, 73-86.

[153] Luque, A. Marti, A. Nature Photonics 2011, 5, 137-138.

[154] Lucena, R. Aguilera, I. Palacios, P. Wahnon, P. Conesa, J. C. Chem. Mater. 2008, 20, 5125-5127. 